\title{
NTP TECHINICAL REPORT ON THE TOXICITY STUDIES OF \\ TRIETHYLAMINE \\ (CASRN 121-44-8) \\ ADMINISTERED BY INHALATION TO \\ F344/N RATS AND \\ B6C3Fl/N MICE
}

NTP TOX 78

MARCH 2018 


\title{
NTP Technical Report on the Toxicity Studies of Triethylamine (CASRN 121-44-8) Administered by Inhalation to F344/N Rats and B6C3F1/N Mice
}

Toxicity Report 78

March 2018

\author{
National Toxicology Program \\ Public Health Service \\ U.S. Department of Health and Human Services \\ ISSN: 2378-8992 \\ Research Triangle Park, North Carolina, USA
}




\section{Foreword}

The National Toxicology Program (NTP) is an interagency program within the Public Health Service (PHS) of the Department of Health and Human Services (HHS) and is headquartered at the National Institute of Environmental Health Sciences of the National Institutes of Health (NIEHS/NIH). Three agencies contribute resources to the program: NIEHS/NIH, the National Institute for Occupational Safety and Health of the Centers for Disease Control and Prevention (NIOSH/CDC), and the National Center for Toxicological Research of the Food and Drug Administration (NCTR/FDA). Established in 1978, the NTP is charged with coordinating toxicological testing activities, strengthening the science base in toxicology, developing and validating improved testing methods, and providing information about potentially toxic substances to health regulatory and research agencies, scientific and medical communities, and the public.

The Toxicity Study Report series began in 1991. The studies described in the Toxicity Study Report series are designed and conducted to characterize and evaluate the toxicologic potential of selected substances in laboratory animals (usually two species, rats and mice). Substances selected for NTP toxicity studies are chosen primarily on the basis of human exposure, level of production, and chemical structure. The interpretive conclusions presented in the Toxicity Study Reports are based only on the results of these NTP studies. Extrapolation of these results to other species, including characterization of hazards and risks to humans, requires analyses beyond the intent of these reports. Selection per se is not an indicator of a substance's toxic potential.

The NTP conducts its studies in compliance with its laboratory health and safety guidelines and FDA Good Laboratory Practice Regulations and must meet or exceed all applicable federal, state, and local health and safety regulations. Animal care and use are in accordance with the Public Health Service Policy on Humane Care and Use of Animals. Studies are subjected to retrospective quality assurance audits before being presented for public review.

NTP Toxicity Study Reports are indexed in the National Center for Biotechnology Information (NCBI) Bookshelf database and are available free of charge electronically on the NTP website (http://ntp.niehs.nih.gov). Additional information regarding this study may be requested through Central Data Management (CDM) at cdm@niehs.nih.gov. Toxicity data are available through NTP's Chemical Effects in Biological Systems (CEBS) database: https://www.niehs.nih.gov/research/resources/database/cebs/index.cfm. 


\section{Table of Contents}

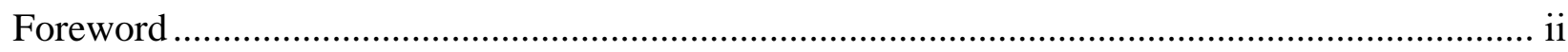

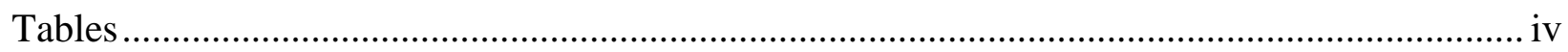

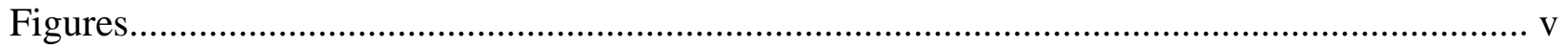

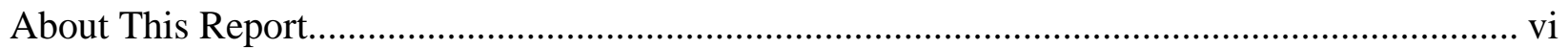

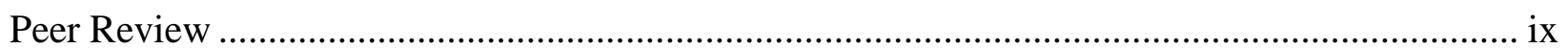

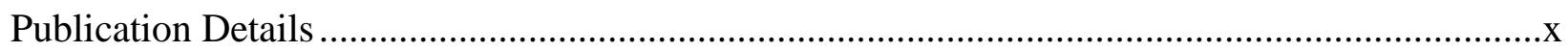

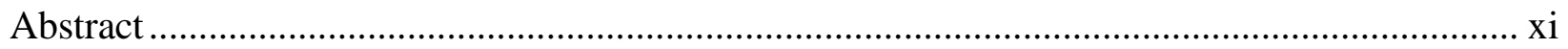

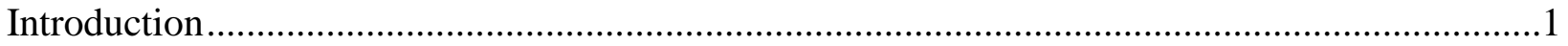

Chemical and Physical Properties ...................................................................................

Production, Use, and Human Exposure …………..............................................................

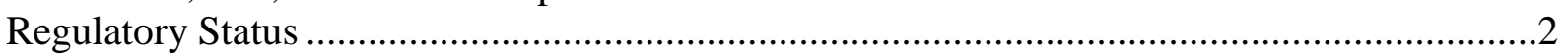

Absorption, Distribution, Metabolism, Excretion, and Toxicokinetics .....................................2

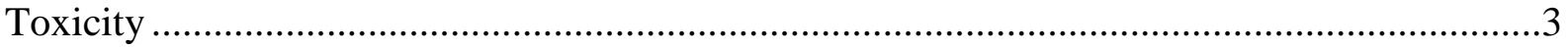

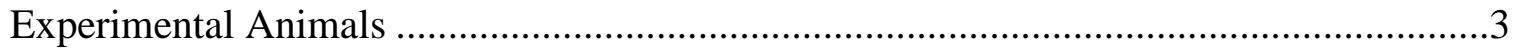

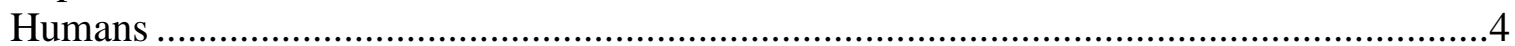

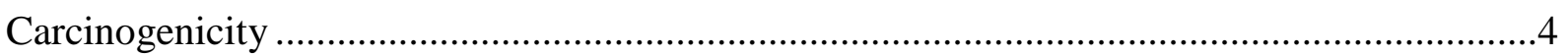

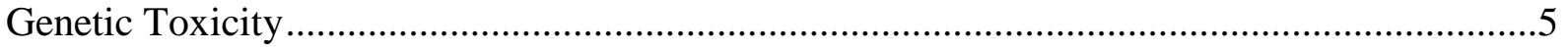

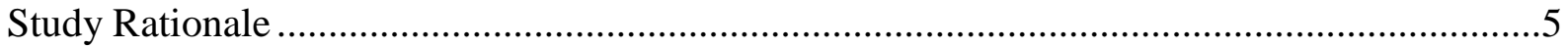

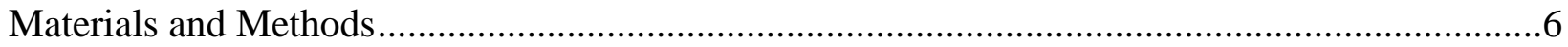

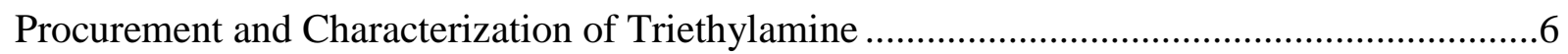

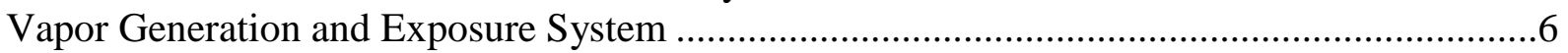

Vapor Concentration Monitoring ....................................................................................

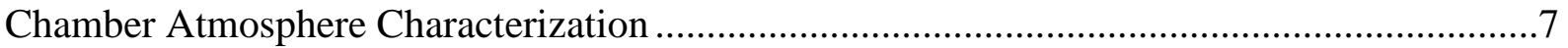

Animal Welfare

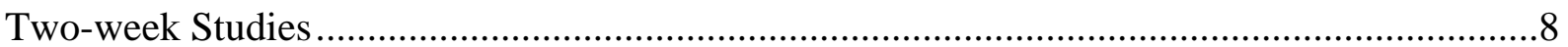

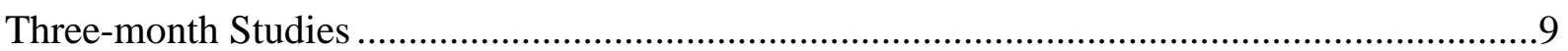

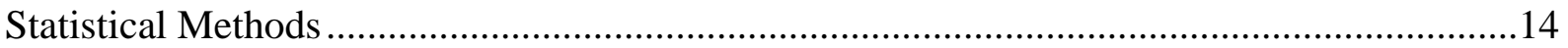

Calculation and Analysis of Lesion Incidences ...........................................................14

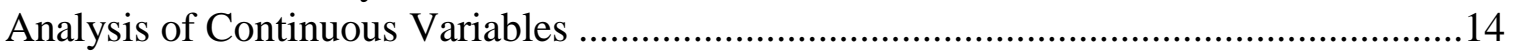

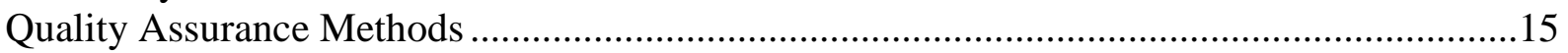

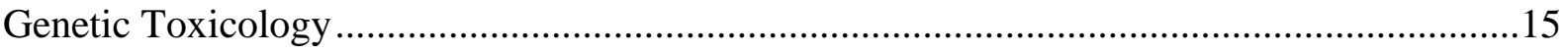

Bacterial Mutagenicity Test Protocol ………………….........................................15

Mouse Peripheral Blood Micronucleus Test Protocol .......................................................15

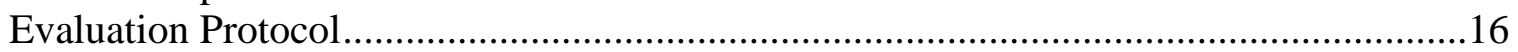

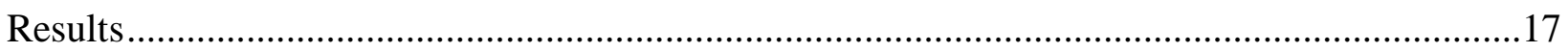

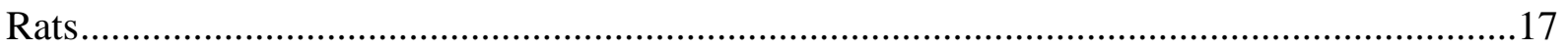

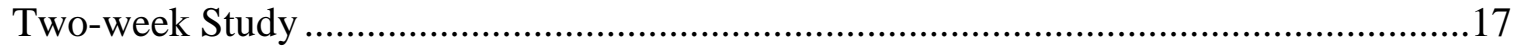

Three-month Study ………………………………….........................................21

Mice

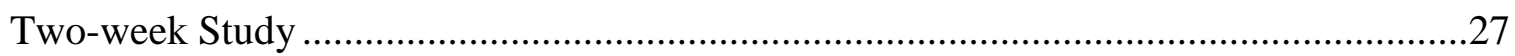




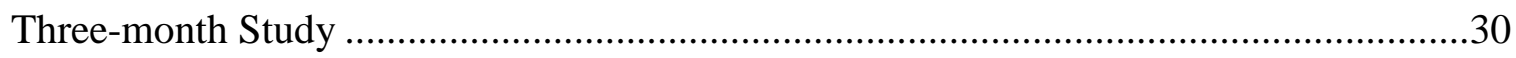

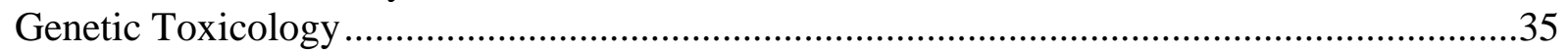

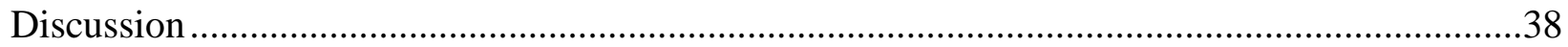

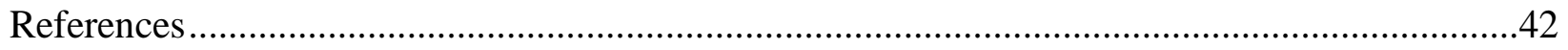

Appendix A. Summary of Nonneoplastic Lesions in Rats and Mice ....................................... A-1

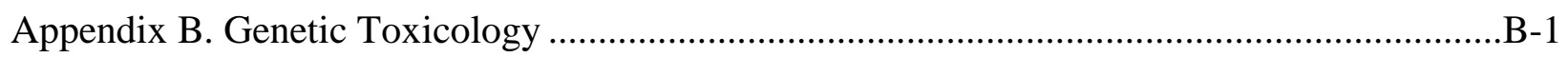

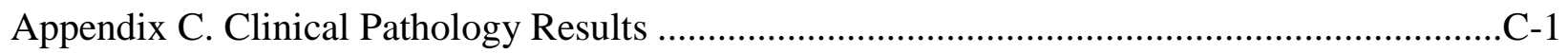

Appendix D. Organ Weights and Organ-Weight-to-Body-Weight Ratios ................................. D-1

Appendix E. Reproductive Tissue Evaluations and Estrous Cycle Characterization ....................E-1

Appendix F. Chemical Characterization and Generation of Chamber Concentrations ................F-1

Appendix G. Ingredients, Nutrient Composition, and Contaminant Levels in NTP 2000

Rat and Mouse Ration ................................................................................. G-1

Appendix H. Sentinel Animal Program Sentinel Animal Program .......................................... H-1

\section{Tables}

Summary of Findings Considered to be Toxicologically Relevant in Rats and Mice Exposed to Triethylamine for Three Months by Inhalation ........................................... xiii

Table 1. Experimental Design and Materials and Methods in the Inhalation Studies of Triethylamine

Table 2. Survival and Body Weights of Rats in the Two-week Inhalation Study of Triethylamine.

Table 3. Incidences of Selected Nonneoplastic Lesions in Rats in the Two-week Inhalation Study of Triethylamine

Table 4. Incidences of Nonneoplastic Lesions of the Eye in Rats in the Two-week Inhalation Study of Triethylamine.

Table 5. Survival and Body Weights of Rats in the Three-month Inhalation Study of Triethylamine

Table 6. Incidences of Selected Nonneoplastic Lesions in Rats in the Three-month Inhalation Study of Triethylamine.

Table 7. Incidences of Nonneoplastic Lesions of the Eye in Rats in the Three-month Inhalation Study of Triethylamine.

Table 8. Survival and Body Weights of Mice in the Two-week Inhalation Study of Triethylamine.

Table 9. Incidences of Selected Nonneoplastic Lesions in Mice in the Two-week Inhalation Study of Triethylamine

Table 10. Incidences of Nonneoplastic Lesions of the Eye in Mice in the Two-week Inhalation Study of Triethylamine

Table 11. Survival and Body Weights of Mice in the Three-month Inhalation Study of Triethylamine

Table 12. Incidences of Nonneoplastic Lesions of the Nose in Mice in the Three-month Inhalation Study of Triethylamine. 


\section{Figures}

Figure 1. Triethylamine (CASRN 121-44-8; Chemical Formula: $\mathrm{C}_{6} \mathrm{H}_{15} \mathrm{~N}$; Molecular Weight: 101.19)

Figure 2. Growth Curves for Rats Exposed to Triethylamine by Inhalation for Three Months

Figure 3. Growth Curves for Mice Exposed to Triethylamine by Inhalation for Three Months

Figure 4. Corneal Epithelial Vacuolation and Necrosis in F344/N Rats and B6C3F1/N Mice Exposed to Triethylamine by Inhalation for up to Two Weeks (H\&E) 36

Figure 5. Nasal Turbinate Hyperostosis and Necrosis in B6C3F1/N Mice Exposed to Triethylamine by Inhalation for Three Months (H\&E)

This report has been reformatted to meet new NTP publishing requirements; its content has not changed. 


\section{About This Report}

National Toxicology Program ${ }^{1}$

${ }^{1}$ Division of the National Toxicology Program, National Institute of Environmental Health Sciences, Research Triangle Park, North Carolina, USA

\section{Collaborators}

D.L. Morgan, G.P. Flake, B. Atkinson, J.B. Bishop, C.R. Blystone, J.A. Dill, P.M. Foster, M.M. Gruebbel, S.L. Grumbein, S.J. Harbo, B.K. Hayden, M.J. Hooth, M.P. Jokinen, A.P. KingHerbert, G.E. Kissling, D.E. Malarkey, B.S. McIntyre, J.C. Peckham, R.A. Renne, H. Seung, M.D. Stout, G.S. Travlos, M.K. Vallant, S. Waidyanatha, N.J. Walker, K.L. Witt, G.W. Wolfe

Division of the National Toxicology Program, National Institute of Environmental Health Sciences, Research Triangle Park, North Carolina, USA

Evaluated and interpreted results and reported findings

D.L. Morgan, Ph.D., Study Scientist

G.P. Flake, M.D., Study Pathologist

J.B. Bishop, Ph.D.

C.R. Blystone, Ph.D.

P.M. Foster, Ph.D.

M.J. Hooth, Ph.D.

A.P. King-Herbert, D.V.M.

G.E. Kissling, Ph.D.

D.E. Malarkey, D.V.M., Ph.D.

B.S. McIntyre, Ph.D.

M.D. Stout, Ph.D.

G.S. Travlos, D.V.M.

M.K. Vallant, M.S., MT

S. Waidyanatha, Ph.D.

N.J. Walker, Ph.D.

K.L. Witt, M.S.

Coordinated NTP Pathology Peer Reviews for the reevaluation of nose and eye (2-week and 3-month studies) (February 28, 2014) and eye (2-week studies; August 7, 2015) (3-month rat study; November 17, 2015)

G.P. Flake, M.D.

\section{Battelle Toxicology Northwest, Richland, Washington, USA}

Conducted studies and evaluated pathology findings

J.A. Dill, Ph.D., Principal Investigator

S.L. Grumbein, D.V.M., Ph.D.

S.J. Harbo, D.V.M.

B.K. Hayden

R.A. Renne, D.V.M. 
Experimental Pathology Laboratories, Inc., Research Triangle Park, North Carolina, USA Conducted pathology review

M.M. Gruebbel, D.V.M., Ph.D.

J.C. Peckham, D.V.M., Ph.D.

Pathology Associates, a Division of Charles River Laboratories, Inc., Research Triangle Park, North Carolina, USA

Coordinated NTP Pathology Peer Review (3-month studies) (June 3, 2004)

M.P. Jokinen, D.V.M.

TherImmune Research Corporation, Gaithersburg, Maryland, USA

Provided SMVCE analysis

G.W. Wolfe, Ph.D., Principal Investigator

B. Atkinson, M.S.

H. Seung, M.S.

\section{Contributors}

NTP Pathology Peer Review, National Institute of Environmental Health Sciences, Research Triangle Park, North Carolina, USA

Participated in NTP Pathology Peer Review (3-month studies) (June 3, 2004)

J.C. Peckham, D.V.M., Ph.D., Experimental Pathology Laboratories, Inc.

Participated in NTP Pathology Peer Review of nose and eye (2-week and 3-month studies) (February 28, 2014)

A.E. Brix, D.V.M., Ph.D., Experimental Pathology Laboratories, Inc.

M.F. Cesta, D.V.M., Ph.D., National Toxicology Program

D.E. Malarkey, D.V.M., Ph.D., National Toxicology Program

T. Osborne, D.V.M., Ph.D., National Toxicology Program

E. Quist, D.V.M., National Toxicology Program

Participated in NTP Pathology Peer Review, reevaluation of eye (2-week studies; August 7, 2015) (3-month rat study; November 17, 2015)

M.M. Gruebbel, D.V.M., Ph.D., Experimental Pathology Laboratories, Inc.

R.A. Herbert, D.V.M., Ph.D., National Toxicology Program

D.E. Malarkey, D.V.M., Ph.D., National Toxicology Program

A.R. Pandiri, Ph.D., National Toxicology Program

C.J. Willson, D.V.M., Ph.D., ILS, Inc.

Experimental Pathology Laboratories, Inc., Research Triangle Park, North Carolina, USA Supervised pathology review

M.H. Hamlin, II, D.V.M., Principal Investigator

Dynamac Corporation, Research Triangle Park, North Carolina, USA

Prepared quality assessment audits

S. Brecher, Ph.D., Principal Investigator

S. Iyer, B.S. 
V.S. Tharakan, D.V.M.

SRA International, Inc., Research Triangle Park, North Carolina, USA

Provided statistical analyses

L.J. Betz, M.S.

P.W. Crockett, Ph.D., Principal Investigator

K.P. McGowan, M.B.A.

Biotechnical Services, Inc., Little Rock, Arkansas, USA

Prepared Toxicity Study Report

S.R. Gunnels, M.A., Principal Investigator

L.M. Harper, B.S.

P. Nader, B.S.E.

D.C. Serbus, Ph.D. 


\section{Peer Review}

The draft NTP Technical Report on the Toxicity Studies of Triethylamine (CASRN 121-44-8) Administered by Inhalation to F344/N Rats and B6C3F1/N Mice was evaluated by the reviewers listed below. These reviewers served as independent scientists, not as representatives of any institution, company, or governmental agency. In this capacity, reviewers determined if the design and conditions of these NTP studies were appropriate and ensured that this NTP Toxicity Study Report presented the experimental results and conclusions fully and clearly.

\section{Peer Reviewers}

\section{William J. Brock, Ph.D.}

Brock Scientific Consulting, LLC

Montgomery Village, Maryland, USA

Kymberly M. Gowdy, M.S., Ph.D.

Department of Pharmacology and Toxicology

Brody School of Medicine

East Carolina University

Greenville, North Carolina, USA

Travis L. Knuckles, Ph.D.

School of Public Health

West Virginia University

Morgantown, West Virginia, USA 


\section{Publication Details}

Publisher: National Toxicology Program

Publishing Location: Research Triangle Park, NC

ISSN: 2378-8992

DOI: https://doi.org/10.22427/NTP-TOX-78

Report Series: NTP Toxicity Report Series

Report Series Number: 78

Official citation: National Toxicology Program (NTP). 2018. NTP technical report on the toxicity studies of triethylamine (CASRN 121-44-8) administered by inhalation to F344/N rats and B6C3F1/N mice. Research Triangle Park, NC: National Toxicology Program. Toxicity Report 78. 


\section{Abstract}

Triethylamine is used primarily as a catalyst to cure the resin systems incorporated into sand cores for foundry molds. It is also used as a curing catalyst in phenol-formaldehyde particle board adhesives, for the precipitation and purification of penicillin and cephalosporin antibiotics, and in the interfacial polymerization process for the production of polycarbonate resins. Triethylamine was nominated by the United Auto Workers Union for long-term toxicity and carcinogenicity studies based on its high production volume, the large number of occupationally exposed workers, and the lack of carcinogenicity data. Male and female F344/N rats and B6C3F1/N mice were exposed to triethylamine (greater than 99\% pure) by whole body inhalation for 2 weeks or 3 months. Genetic toxicology studies were conducted in Salmonella typhimurium and mouse peripheral blood erythrocytes.

In the 2-week toxicity studies, groups of five male and five female F344/N rats and B6C3F1/N mice were exposed to triethylamine at concentrations of $0,100,200,400,800$, or 1,000 ppm, 6 hours plus $\mathrm{T}_{90}(12$ minutes) per day, 5 days per week for 16 (rats) or 17 (mice) days. All rats exposed to 800 or $1,000 \mathrm{ppm}$ died after exposure on day 1 ; all mice exposed to 800 or $1,000 \mathrm{ppm}$ died between day 1 (postexposure) and day 11 . The final mean body weights of all surviving groups of exposed male rats and 200 and $400 \mathrm{ppm}$ female rats were significantly less than those of the chamber controls. In mice, the final mean body weights of $400 \mathrm{ppm}$ males and females were significantly less than those of the chamber controls. Possible chemical-related clinical findings in $400 \mathrm{ppm}$ rats and mice included lethargy, abnormal breathing, ataxia, tremor, nasal discharge (rats), and thinness (mice). Kidney weights of $100 \mathrm{ppm}$ female rats were significantly greater than those of the chamber controls.

In the nose of male rats, there were significantly increased incidences of respiratory epithelium hyperplasia in all surviving exposed groups; significantly increased incidences of suppurative inflammation in the 200 and 400 ppm groups; significantly increased incidences of turbinate necrosis, squamous metaplasia of the respiratory epithelium, and respiratory epithelium ulcer in the $400 \mathrm{ppm}$ group; and a significantly increased incidence of olfactory epithelium atrophy in the 200 ppm group. In the nose of female rats, there were significantly increased incidences of suppurative inflammation, squamous metaplasia of the respiratory epithelium, and respiratory epithelium ulcer in the $400 \mathrm{ppm}$ group; significantly increased incidences of respiratory epithelium hyperplasia in the 100 and 200 ppm groups; and a significantly increased incidence of olfactory epithelium atrophy in the 200 ppm group.

All rats that died early had necrosis of the respiratory epithelium of the nose and necrosis of the bronchus. In the lung of surviving groups of male and female rats, there were significantly increased incidences of bronchus degeneration in the 200 and 400 ppm groups and significantly increased incidences of suppurative inflammation and regeneration of the bronchus in the 400 ppm groups. Rats dying early often showed corneal degeneration or necrosis, and a few rats in the 100 and 200 ppm groups exhibited subepithelial vesicles of the cornea.

Turbinate necrosis occurred in the nose of all exposed mice except the $100 \mathrm{ppm}$ groups. There were significantly increased incidences of olfactory epithelium atrophy in the nose of all surviving groups of exposed mice, and significantly increased incidences of acute inflammation and squamous metaplasia of the respiratory epithelium in 200 and $400 \mathrm{ppm}$ mice. 
Lung lesions observed only in the groups with early mortality included necrosis of the bronchus in male and female mice and cytoplasmic vacuolization of the bronchus in females. In $400 \mathrm{ppm}$ mice, incidences of chronic active inflammation of the bronchus were increased. Groups of mice with early mortality also had corneal necrosis and cataracts.

In the 3-month toxicity studies, groups of 10 male and 10 female F344/N rats and B6C3F1/N mice were exposed to triethylamine at concentrations of $0,12.5,25,50,100$, or $200 \mathrm{ppm}, 6$ hours plus $\mathrm{T}_{90}$ (12 minutes) per day, 5 days per week for 14 weeks. All exposed rats and mice survived to the end of the studies. Body weights of $200 \mathrm{ppm}$ rats and mice were significantly less than those of the chamber controls. In male rats, differences in reproductive parameters included decreased spermatozoa motility at $50 \mathrm{ppm}$ or greater and increased spermatid heads per $\mathrm{mg}$ testis in the 100 and 200 ppm groups.

In the olfactory epithelium of the nose of rats, there were significantly increased incidences of atrophy in males exposed to $50 \mathrm{ppm}$ or greater and in females exposed to $25 \mathrm{ppm}$ or greater. In the respiratory epithelium of the nose of rats, there were significantly increased incidences of hyperplasia in males and females exposed to $25 \mathrm{ppm}$ or greater. In the lung of female rats, there were significantly increased incidences of histiocyte cellular infiltration of the alveolus in the 100 and 200 ppm groups. Corneal lesions of the eye were noted in four males and six females exposed to $200 \mathrm{ppm}$.

In the olfactory epithelium of the nose of mice, there were significantly increased incidences of atrophy in males and females exposed to $50 \mathrm{ppm}$ or greater and significantly increased incidences of cytoplasmic vacuolization in $50 \mathrm{ppm}$ males and females. In the respiratory epithelium of the nose of mice, there were significantly increased incidences of squamous metaplasia in $200 \mathrm{ppm}$ males and females. There were significantly increased incidences of turbinate hyperostosis in all exposed groups of male and female mice and significantly increased incidences of turbinate necrosis in $200 \mathrm{ppm}$ males and females.

Triethylamine was not mutagenic in any of four strains of S. typhimurium, with or without exogenous metabolic activation. An equivocal increase, based on a trend test analysis, in the frequency of micronucleated erythrocytes was observed in peripheral blood of male mice sampled at the end of the 3-month study; no increase in micronucleated erythrocytes was seen in female mice.

Under the conditions of the 3-month inhalation studies, there were treatment-related lesions in male and female rats and mice. The major targets of triethylamine exposure in rats and mice included the nose and eyes. In rats, the most sensitive measure of triethylamine exposure was respiratory epithelium hyperplasia of the nasal cavity with a lowest-observed-effect level (LOEL) of $12.5 \mathrm{ppm}$ in males and females. In mice, the most sensitive measure of triethylamine exposure was turbinate hyperostosis of the nasal cavity with a LOEL of $12.5 \mathrm{ppm}$ in males and females.

Synonyms: (Diethylamino) ethane; ethanamine, $N, N$-diethyl- (9CI); $N, N$-diethylethanamine; triethyl-(diethylamino) ethaneamine 
Summary of Findings Considered to be Toxicologically Relevant in Rats and Mice Exposed to Triethylamine for Three Months by Inhalation

\begin{tabular}{|c|c|c|c|c|}
\hline & $\begin{array}{c}\text { Male } \\
\text { F344/N Rats }\end{array}$ & $\begin{array}{c}\text { Female } \\
\text { F344/N Rats }\end{array}$ & $\begin{array}{c}\text { Male } \\
\text { B6C3F1/N Mice }\end{array}$ & $\begin{array}{c}\text { Female } \\
\text { B6C3F1/N Mice }\end{array}$ \\
\hline $\begin{array}{l}\text { Exposure } \\
\text { concentrations }\end{array}$ & $\begin{array}{l}0,12.5,25,50,100 \\
200 \text { ppm }\end{array}$ & $\begin{array}{l}0,12.5,25,50,100 \\
200 \mathrm{ppm}\end{array}$ & $\begin{array}{l}0,12.5,25,50,100 \\
200 \mathrm{ppm}\end{array}$ & $\begin{array}{l}0,12.5,25,50,100 \\
200 \mathrm{ppm}\end{array}$ \\
\hline Survival rates & $\begin{array}{l}10 / 10,10 / 10,10 / 10 \\
10 / 10,10 / 10,10 / 10\end{array}$ & $\begin{array}{l}10 / 10,10 / 10,10 / 10 \\
10 / 10,10 / 10,10 / 10\end{array}$ & $\begin{array}{l}10 / 10,10 / 10,10 / 10 \\
10 / 10,10 / 10,10 / 10\end{array}$ & $\begin{array}{l}10 / 10,10 / 10,10 / 10 \\
10 / 10,10 / 10,10 / 10\end{array}$ \\
\hline Body weights & $\begin{array}{l}200 \text { ppm group } 13 \% \\
\text { less than the chamber } \\
\text { control group }\end{array}$ & $\begin{array}{l}200 \text { ppm group } 13 \% \\
\text { less than the chamber } \\
\text { control group }\end{array}$ & $\begin{array}{l}200 \text { ppm group } 15 \% \\
\text { less than the chamber } \\
\text { control group }\end{array}$ & $\begin{array}{l}200 \text { ppm group } 11 \% \\
\text { less than the chamber } \\
\text { control group }\end{array}$ \\
\hline Clinical observations & No effect observed & No effect observed & No effect observed & No effect observed \\
\hline Organ weights & No effect observed & No effect observed & No effect observed & No effect observed \\
\hline Clinical pathology & No effect observed & No effect observed & $\begin{array}{l}\text { No effect observed } \\
\text { (hematology only) }\end{array}$ & $\begin{array}{l}\text { No effect observed } \\
\text { (hematology only) }\end{array}$ \\
\hline Reproductive effects & $\begin{array}{l}\text { Sperm motility } \\
\text { decreased }\end{array}$ & No effect observed & No effect observed & No effect observed \\
\hline Nonneoplastic effects & $\begin{array}{l}\text { Nose: respiratory } \\
\text { epithelium, } \\
\text { hyperplasia }(0 / 10, \\
\text { 3/10, } 9 / 10,9 / 10, \\
\text { 10/10, 10/10); } \\
\text { olfactory epithelium, } \\
\text { atrophy }(0 / 10,0 / 10, \\
\text { 0/10, 10/10, 10/10, } \\
\text { 10/10) } \\
\text { Eye: cornea, } \\
\text { mineralization }(0 / 9, \\
\text { 0/10, 0/10, } 0 / 10,1 / 10, \\
3 / 10) ; \text { cornea, } \\
\text { epithelium, } \\
\text { vacuolation }(0 / 9,0 / 10, \\
\text { 0/10, } 0 / 10,0 / 10,2 / 10) \text {; } \\
\text { cornea, necrosis }(0 / 9, \\
0 / 10,0 / 10,0 / 10,0 / 10, \\
\text { 1/10) }\end{array}$ & $\begin{array}{l}\text { Nose: respiratory } \\
\text { epithelium, } \\
\text { hyperplasia }(0 / 10, \\
3 / 10,9 / 10,10 / 10, \\
\text { 10/10, } 10 / 10) ; \\
\text { olfactory epithelium, } \\
\text { atrophy }(0 / 10,0 / 10, \\
\text { 4/10, 10/10, 10/10, } \\
\text { 10/10) } \\
\text { Eye: cornea, } \\
\text { mineralization }(0 / 10, \\
\text { 0/10, } 0 / 10,0 / 10,0 / 10, \\
\text { 2/10); cornea, vesicle, } \\
\text { subepithelial }(0 / 10, \\
\text { 0/10, } 0 / 10,0 / 10,0 / 10, \\
3 / 10) ; \text { cornea, necrosis } \\
(0 / 10,0 / 10,0 / 10,0 / 10, \\
0 / 10,1 / 10)\end{array}$ & $\begin{array}{l}\text { Nose: turbinate, } \\
\text { hyperostosis }(0 / 10, \\
10 / 10,9 / 10,10 / 10, \\
10 / 10,10 / 10) ; \\
\text { olfactory epithelium, } \\
\text { atrophy }(0 / 10,0 / 10, \\
0 / 10,9 / 10,10 / 10, \\
10 / 10)\end{array}$ & $\begin{array}{l}\text { Nose: turbinate, } \\
\text { hyperostosis }(0 / 10, \\
8 / 10,10 / 10,10 / 10, \\
9 / 10,10 / 10) ; \text { olfactory } \\
\text { epithelium, atrophy } \\
(0 / 10,0 / 10,0 / 10, \\
10 / 10,10 / 10,10 / 10)\end{array}$ \\
\hline
\end{tabular}

\section{Genetic toxicology}

Bacterial gene mutations (in vitro): Negative in Salmonella typhimurium strains TA98, TA100, TA1535, and TA1537 with and without exogenous metabolic activation

Micronucleated reticulocytes (in vivo): 


\section{Introduction}<smiles>CCN(CC)CC</smiles>

Figure 1. Triethylamine (CASRN 121-44-8; Chemical Formula: $\mathrm{C}_{6} \mathrm{H}_{15} \mathrm{~N}$; Molecular Weight: 101.19)

Synonyms: (Diethylamino) ethane; ethanamine, $N, N$-diethyl- (9CI); $N, N$-diethylethanamine; triethyl-(diethylamino) ethaneamine.

\section{Chemical and Physical Properties}

Triethylamine is a colorless liquid with a strong ammonia-like odor (odor threshold $0.48 \mathrm{ppm}$ ) and is miscible in water, ethanol, and ethyl ether. Triethylamine has a relatively high vapor pressure $\left(54 \mathrm{~mm} \mathrm{Hg} \text { at } 20^{\circ} \mathrm{C}\right)^{1}$, and the vapor is explosive when exposed to heat or flame. Triethylamine is a dangerous fire hazard when exposed to heat, flame, or oxidizers and when heated to decomposition, it emits toxic nitrogen oxide fumes ${ }^{2}$.

\section{Production, Use, and Human Exposure}

Triethylamine is produced by reacting ammonia with ethanol, $N, N$-diethylacetamide with lithium aluminum hydride, or ethyl chloride with ammonia under heat and pressure ${ }^{3}$. Large-scale production of triethylamine is generally by high temperature, high pressure reactions of ammonia and an alcohol over a dehydration catalyst or a dehydrogenation catalyst ${ }^{4}$. Yields of mixed amines from the reaction of ammonia and alcohol are high $(\geq 80 \%)$. Pure amines are obtained by continuous extractions and distillations.

Triethylamine is listed as a high production volume chemical, indicating that greater than 1 million pounds were produced in or imported into the United States in 1990 and/or 1994 ${ }^{5}$. Nonconfidential production volume information indicates that production ranged from 10 to 50 million pounds in 1994,1998 , and $2002^{5}$.

The largest use of triethylamine is as a catalyst to cure the resin systems incorporated into sand cores for foundry molds ${ }^{6}$. In this procedure, triethylamine is usually stored in a liquid form at room temperature and during its use, it is vaporized and introduced into the system as a gas $7 ; 8$. Workers must wear appropriate eye and respiratory protection ${ }^{9}$, and proper ventilation of the work area is necessary ${ }^{10}$.

Annually in the United States, approximately 5 million pounds of triethylamine are used as a curing catalyst in phenol-formaldehyde particle board adhesives, 2 to 3 million pounds of triethylamine are used for the precipitation and purification of penicillin and cephalosporin antibiotics, and 1 to 2 million pounds of triethylamine are used in the interfacial polymerization process for the production of polycarbonate resins. Triethylamine is also used as an ingredient in sealing paint $(0.5 \% \mathrm{w} / \mathrm{w})^{11}$; in the manufacture of some paper and board adhesives; as a stabilizer for the chlorinated solvents perchlorethylene and trichloroethylene ${ }^{6}$; as an antilivering agent for urea- and melamine-based enamels; in the recovery of gelled paint vehicles; as an accelerator 
activator for rubber; as a corrosion inhibitor; as a propellant; as a wetting, penetrating, and waterproofing agent of quaternary ammonia compounds; as an emulsifying agent for dyes; for the production of textile treatment agents; as an ingredient of photographic development accelerator; for drying printing inks; in carpet cleaners; in the production of herbicides and pesticides and in the preparation of emulsifiers for pesticides; in nonnutritive sweeteners, ketenes, and salts; and for the desalination of water ${ }^{12}$.

The National Institute for Occupational Safety and Health (NIOSH) ${ }^{13}$ estimated that 68,091 workers were potentially exposed to triethylamine in the workplace annually. Occupational exposure to triethylamine can occur through inhalation and dermal contact in industries where this chemical is used or produced. Because triethylamine is vaporized when used in mold production in iron foundries, inhalation of the vapors is a major route of occupational exposure. The general population may be exposed to triethylamine by inhalation of ambient air, ingestion of food, and dermal contact with this chemical or products containing triethylamine.

\section{Regulatory Status}

The Occupational Safety and Health Administration airborne permissible exposure limit for triethylamine is $25 \mathrm{ppm}\left(100 \mathrm{mg} / \mathrm{m}^{3}\right)$ averaged over an 8 -hour workshift ${ }^{14}$. The American Conference of Governmental Industrial Hygienists ${ }^{15}$ recommended airborne exposure limit is $1 \mathrm{ppm}$ triethylamine averaged over an 8-hour workshift and $3 \mathrm{ppm}$ as a 15-minute short-term exposure limit (STEL). NIOSH ${ }^{16}$ recommended an exposure limit of $10 \mathrm{ppm}$ (time-weighted average; TWA), a STEL of $15 \mathrm{ppm}$, and an immediately dangerous to life value of $200 \mathrm{ppm}$. These exposure limits were based on the adverse effects of triethylamine on the eyes and skin.

\section{Absorption, Distribution, Metabolism, Excretion, and Toxicokinetics}

No information was found on the absorption, distribution, metabolism, or excretion of triethylamine in rodents.

Åkesson et al. ${ }^{17 ; 18}$ investigated the absorption, distribution, metabolism, excretion, and toxicokinetics of triethylamine in five healthy men. The subjects were exposed to triethylamine concentrations of $10,25,35$, or $50 \mathrm{mg} / \mathrm{m}^{3}(2.4,6.0,8.4$, or $12.0 \mathrm{ppm})$ for 4 or 8 hours. The concentrations of triethylamine in exhaled air were about $20 \%$ of those in inhaled air indicating significant absorption. Analysis of urine showed that most of the triethylamine was excreted unchanged. An average of $24 \%$ of the triethylamine was oxidatively metabolized into triethylamine-N-oxide, but with a wide interindividual variation of $15 \%$ to $36 \%$. A similar observation was reported following exposure of 20 workers employed at a polyurethane foam manufacturing plant to approximately $500 \mu \mathrm{mol}$ (calculated as TWA $\times$ pulmonary ventilation) triethylamine per day ${ }^{19}$. Less than $0.3 \%$ of the inhaled triethylamine was excreted as diethylamine. Exogenous aliphatic amines are generally metabolized by monoamine oxidase and diamine oxidase. Monoamine oxidase catalyses the deamination of primary, secondary, and tertiary amines to form ammonia, which is ultimately converted to urea ${ }^{20}$. The plasma and urinary concentrations of triethylamine and triethylamine-N-oxide decreased rapidly after the end of the exposure. The mean urinary excretion half-life for triethylamine and the oxide were approximately 3 and 4 hours, respectively. 
Åkesson et al. ${ }^{18}$ also investigated the disposition of triethylamine in four healthy men after a single oral dose of $25 \mathrm{mg}$ or an intravenous dose of $15 \mathrm{mg}$. Triethylamine was efficiently absorbed from the gastrointestinal tract after oral administration. Total doses recovered in urine as triethylamine and triethylamine-N-oxide after oral and intravenous administration were $90 \%$ and $97 \%$, respectively. Triethylamine was excreted into the gastric juice where levels were approximately 30 times the levels in plasma. Excretion of triethylamine by exhalation was minimal. The average plasma and urine half-lives following oral administration were 2.9 and 2.8 hours, respectively.

\section{Toxicity}

\section{Experimental Animals}

In early studies of triethylamine toxicity, Carpenter et al. ${ }^{21}$ reported that acute inhalation exposure of guinea pigs to 2,000 ppm for 2 hours resulted in the death of four of six animals. Exposure to 1,000 ppm for 4 hours resulted in the death of two of six animals and no deaths were observed after 4 hours of exposures to 250 or $500 \mathrm{ppm}$ triethylamine. In other acute studies, Brieger and Hodes ${ }^{22}$ exposed rabbits (strain not reported) to 50 or $100 \mathrm{ppm}\left(210\right.$ or $414 \mathrm{mg} / \mathrm{m}^{3}$ ) triethylamine vapor 7 hours/day, 5 days per week for 6 weeks. Exposure to 100 ppm resulted in pulmonary edema, hemorrhage, moderate peribronchitis, and vascular thickening.

Extrapulmonary effects were noted in the kidney and liver and were characterized as parenchymal degeneration with cell necrosis. Similar but less severe lesions were observed in the lung, kidney, and liver of animals exposed to $50 \mathrm{ppm}$. Severe ocular irritation was observed in rabbits exposed to 50 or 100 ppm triethylamine for 30 days. A researcher accidentally exposed to $50 \mathrm{ppm}$ triethylamine (duration unknown) during this animal study experienced severe corneal erosion and edema.

In a subchronic inhalation study, albino rats exposed to $3.14 \mathrm{ppm}\left(13.01 \mathrm{mg} / \mathrm{m}^{3}\right)$ triethylamine for 3 months exhibited changes in the lungs, brain, and liver ${ }^{23}$. In the lungs, there was infiltration of the perivascular connective tissue by white blood cells, thickening of the interalveolar walls and shedding of the alveolar epithelium. In the brain, there was swelling, disruption of nuclei, necrosis, disappearance of neurons, reduced cytochrome $\mathrm{C}$ oxidase activity, accumulation of lipids in the cerebral cortex, and reduced staining intensity of sulfhydryl groups. In the liver, there was a reduction in glycogen content. These effects were not observed after exposure to 0.04 or $0.4 \mathrm{ppm}\left(0.16\right.$ or $\left.1.71 \mathrm{mg} / \mathrm{m}^{3}\right)$ triethylamine.

Rats exposed to concentrations of 7.2 to $19 \mathrm{ppm}\left(30\right.$ to $\left.80 \mathrm{mg} / \mathrm{m}^{3}\right)$ triethylamine, 3 hours/day for 6 months exhibited decreased body weights, changes in nervous system function (details not provided), hypohemoglobinemia, increased blood reticulocytes, and chronic inflammation of the lungs ${ }^{3}$.

Lynch et al. ${ }^{24}$ exposed male and female F344 rats to 0,25 , or 247 ppm triethylamine vapors, 6 hours/day, 5 days a week for up to 28 weeks. No significant treatment-related effects were observed on body weights, hematology, clinical chemistry, or electrocardiographic indices after exposure to either concentration. No histopathologic lesions were detected in any of the organs examined, including the nasal passages. 
Dermal exposure to triethylamine has been demonstrated to cause severe skin damage in several species of laboratory animals. Skin injury is attributed to the potent alkalinity of triethylamine. A $70 \%$ solution of triethylamine placed on the skin of guinea pigs for 2 hours caused severe skin injury $^{25}$. Severe skin damage was also observed in New Zealand white rabbits that had $0.5 \mathrm{~mL}$ triethylamine applied to intact or abraded occluded skin for 3 minutes ${ }^{26 ; 27}$ or 24 hours ${ }^{28}$. Dermal application of 2,000 or $5,000 \mathrm{mg} / \mathrm{kg}$ triethylamine to rabbits (strain not provided) resulted in $75 \%$ and $100 \%$ mortality, respectively ${ }^{29}$. Severe toxicity leading to death was observed in New Zealand white rabbits that had 1 or $2 \mathrm{~mL} / \mathrm{kg}$ triethylamine applied to the skin for 24 hours $^{30 ; 31}$. Necropsies of dead rabbits revealed dark lungs and kidneys, pale spleen, and pale, mottled liver.

\section{Humans}

Occupational exposure to triethylamine is reported to cause irritation of the respiratory tract, the eyes, and mucous membranes; however, published studies evaluating the pulmonary effects of triethylamine on humans could not be found in the literature. Reports on human exposures were primarily concerned with reported eye irritation and vision symptoms of blurriness, halo vision and glaucopsia (blue, hazy vision) $)^{22 ; 32-34}$. These symptoms are typically short-lived, lasting about an hour after the end of exposure and are attributed to light scattering associated with corneal irritation and edema ${ }^{35}$. Corneal irritation and edema result from direct action of triethylamine on the corneal epithelium.

Åkesson et al. ${ }^{34}$ exposed human volunteers to 2.5 to $12 \mathrm{ppm}\left(10\right.$ to $\left.48 \mathrm{mg} / \mathrm{m}^{3}\right)$ triethylamine for 4 to 8 hours. Severe visual disturbances were reported in two volunteers exposed to $12 \mathrm{ppm}$ triethylamine vapor for 4 hours. Symptoms included hazing of visual fields, bluish halos around lights, and slight ocular irritation. Ocular examination revealed a slight decrease in visual acuity and pronounced corneal edema. Symptoms disappeared after 4 to 4.5 hours. Similar but less severe effects occurred after 2 hours of exposure to $8.5 \mathrm{ppm}\left(34 \mathrm{mg} / \mathrm{m}^{3}\right)$; slight visual disturbance was reported after 4 to 6 hours of exposure to $4.5 \mathrm{ppm}\left(18 \mathrm{mg} / \mathrm{m}^{3}\right)$, and no adverse effects were noted after exposure to $2.5 \mathrm{ppm}\left(10 \mathrm{mg} / \mathrm{m}^{3}\right)$ triethylamine for 8 hours. In a subsequent study, Åkesson et al. ${ }^{33}$ reported that five of 19 workers exposed to triethylamine at a polyurethane foam production plant reported visual disturbances described as foggy vision, blue haze, and sometimes halo phenomena. At the sites within the plant where workers reported symptoms, the triethylamine concentrations ranged from 1 to $6 \mathrm{ppm}$ ( 4 to $24 \mathrm{mg} / \mathrm{m}^{3}$ ). No effects were observed when the triethylamine concentrations were decreased to $1.5 \mathrm{ppm}\left(6 \mathrm{mg} / \mathrm{m}^{3}\right)$. Visual disturbances in workers have been correlated with occupational exposures to triethylamine vapor in other studies ${ }^{8 ; 35 ; 36}$.

\section{Carcinogenicity}

Information on the carcinogenicity of triethylamine in humans or animals is sparse. In a Danish foundry, molders exposed to a variety of chemicals, including triethylamine, had a significantly increased mortality due to bladder cancer when compared to other skilled workers ${ }^{37}$. Workers were followed for up to 10 years. Coadministration of $0.5 \%(5,000 \mathrm{mg} / \mathrm{kg}$ feed $)$ triethylamine hydrochloride (37 mMol/kg feed) and $0.5 \%$ nitrite in feed to SIV50 rats for 1 year did not result in detectable tumors ${ }^{38}$. Triethylamine was not administered as a single compound to rats in this study. 


\section{Genetic Toxicity}

Triethylamine was not mutagenic in Salmonella typhimurium strains TA98, TA100, TA1535, or TA1537, when tested up to a maximum of $10,000 \mu \mathrm{g} /$ plate with or without induced rat or hamster liver S9 activation enzymes (Zeiger et al. ${ }^{39}$; Appendix B).

\section{Study Rationale}

Triethylamine was nominated by the International Union, United Automobile, Aerospace and Agricultural Implement Workers of America based on its widespread use and resulting occupational exposures, concern regarding respiratory and ocular effects, and the lack of chronic toxicity and carcinogenicity data. Chronic studies of triethylamine were not conducted because its subchronic toxicity was similar to that of diethylamine, and there was greater interest in a chronic study of diethylamine because of its potential to form nitrosamines. 


\section{Materials and Methods}

\section{Procurement and Characterization of Triethylamine}

Triethylamine was obtained from Alkyl Amines Chemicals, Limited (Maharashtra, India) in one lot (CE/04/01) that was used in the 2-week and 3-month studies. Identity and purity analyses were conducted by the analytical chemistry laboratories at Chemir/Polytech Laboratories, Inc. (Maryland Heights, MO), Galbraith Laboratories, Inc., (Knoxville, TN), and Research Triangle Institute (RTI) (Research Triangle Park, NC), and by the study laboratory at Battelle Toxicology Northwest (Richland, WA) (Appendix F). Reports on analyses performed in support of the triethylamine studies are on file at the National Institute of Environmental Health Sciences.

The chemical, a highly alkaline colorless liquid with a strong ammonia odor, was identified as triethylamine using fourier transform infrared and proton nuclear magnetic resonance spectroscopy and gas chromatography (GC) coupled with mass spectrometry.

Karl Fischer titration indicated 221 ppm water. Elemental analyses for carbon, hydrogen, and nitrogen were in agreement with the theoretical values for triethylamine. GC with flame ionization detection (FID) indicated one major peak and no impurities with areas greater than $0.1 \%$ relative to the total peak area. The overall purity of lot CE/04/01 was determined to be greater than $99 \%$.

An additional analysis was performed to determine if triethylamine oxide (TEAO), a degradation product that can be found in the test chemical from reaction with oxygen, was present. The presence of TEAO was determined by controlled thermal degradation of TEAO to diethylamine $^{40}$ with subsequent analysis using GC coupled with mass spectrometry. Results indicated that, if present, the concentration of TEAO was less than $0.1 \%$.

To ensure stability, the test chemical was stored at controlled room temperature in the original shipping containers (55-gallon metal drums). Periodic reanalyses of the bulk chemical were performed during the 2-week and 3-month studies using GC/FID, and no degradation of the bulk chemical was detected.

\section{Vapor Generation and Exposure System}

Triethylamine was pumped through a preheater (2-week studies) into a heated glass column filled with glass beads to increase the surface area for evaporation. Heated nitrogen entering the column from below vaporized the chemical as it was conveyed out of the generator and into a short vapor distribution manifold. Concentration in the manifold was determined by the chemical pump and nitrogen flow rates. The pressure in the distribution manifold was kept fixed to ensure consistent flow through the manifold and into the chambers as the flow of vapor to each chamber was adjusted. Precision metering valves controlled flow to each chamber. Three-way exposure valves, mounted downstream from all metering valves directed all chemical to exhaust until the generation system was stable and exposures were ready to proceed. When the exposure started, the three-way valve was rotated to allow the flow of triethylamine vapor through the Teflon® delivery line into the chamber inlet duct where it was further mixed and diluted with conditioned chamber air to achieve the desired exposure concentration. 
The study laboratory designed the inhalation exposure chamber (Harford Systems Division of Lab Products, Inc., Aberdeen, MD) so that uniform vapor concentrations could be maintained throughout the chamber with the catch pans in place. The total active mixing volume of each chamber was $1.7 \mathrm{~m}^{3}$. A condensation particle counter was used with and without animals in the exposure chambers to ensure that triethylamine vapor, and not aerosol, was produced. No particle counts above the minimum resolvable level (approximately 200 particles $/ \mathrm{cm}^{3}$ ) were detected.

\section{Vapor Concentration Monitoring}

Summaries of the chamber vapor concentrations are given in Table F-2 and Table F-3. Concentrations in the exposure chambers were monitored by an on-line gas chromatograph. Samples were drawn from each exposure chamber approximately every 20 minutes during each 6-hour exposure using a stream-select valve. This valve directed a continuous stream of sampled atmosphere to a sampling valve with a sample loop. Both valves were mounted in a dedicated oven. A vacuum regulator maintained a constant pressure in the sample loop to compensate for variations in sample line pressure. An in-line flow meter between the vacuum regulator and gas chromatograph allowed digital measurement of sample flow.

The on-line gas chromatograph was checked throughout the day for instrument drift against an on-line standard of triethylamine vapor supplied by a standard generator. The on-line gas chromatograph was calibrated by a comparison of chamber concentration data to data from grab samples that were collected with acrylic ester sampling tubes and extracted with methylene chloride containing cyclopentylamine as an internal standard and analyzed by an off-line gas chromatograph. Known values of chamber atmosphere were sampled at a constant flow rate ensured by a calibrated critical orifice. The off-line gas chromatograph was calibrated with gravimetrically prepared standards of triethylamine and the internal standard (triethylamine) in methylene chloride.

\section{Chamber Atmosphere Characterization}

Buildup and decay rates for chamber vapor concentrations were determined with and without animals present in the chambers. At a chamber airflow rate of 15 air changes per hour, the theoretical value for the time to achieve $90 \%$ of the target concentration after the beginning of vapor generation $\left(\mathrm{T}_{90}\right)$ and the time for the chamber concentration to decay to $10 \%$ of the target concentration after vapor generation was terminated $\left(T_{10}\right)$ was approximately 9.4 minutes. A $T_{90}$ value of 12 minutes was selected for all studies.

The uniformity of vapor concentration in the inhalation exposure chambers without animals present was evaluated before the 3-month studies began; in addition, concentration uniformity with animals in the chambers was measured once during the 2-week and 3-month studies. The vapor concentration was measured using the on-line gas chromatograph with the streamselection valve fixed in one position to allow continuous monitoring from a single input line. Chamber concentration uniformity was maintained throughout the studies.

The persistence of triethylamine in the chambers after vapor delivery ended was determined by monitoring the vapor concentration in the $1,000 \mathrm{ppm}$ chambers with animals present in the 2-week studies and in the $200 \mathrm{ppm}$ chambers with and without animals present in the 3-month 
studies. In the 2 -week studies, the concentration decreased to $1 \%$ of the target concentration within 21 minutes. In the 3-month studies, the concentration decreased to $1 \%$ of the target concentration within 56 minutes with animals present and within 22 minutes without animals present.

Test article stability in the distribution lines and low and high exposure concentration chambers was characterized during the 2-week and 3-month studies; characterization of the chamber test atmosphere during the first and last 2 hours of one generation day was conducted with animals present in the exposure chambers. Similar stability studies were conducted prior to the start of the 3-month studies; in these studies, exposure chamber measurements were taken from unoccupied chambers. Additional samples were collected from the generator reservoir during the 2-week studies and prior to the 3-month studies. Samples of the bulk chemical taken from the generator reservoir were diluted with methylene chloride containing diethylamine as an internal standard and analyzed by GC. Samples of the test atmosphere from the distribution lines and exposure chambers were collected with sorbent tubes, extracted with methylene chloride, and analyzed using GC. To assess whether impurities or degradation products co-eluted with the test chemical or the solvent, a second analysis of the test atmosphere samples was performed with GC using a polar column that permitted resolution of compounds with similar boiling points but small differences in polarity. Some of the samples of the test atmosphere from the distribution lines and exposure chambers in these studies contained one impurity with an area greater than $0.1 \%$ of the total peak area; the identity of this impurity was confirmed as diethylamine using GC with mass spectrometric detection. The highest concentrations of diethylamine noted in the test atmosphere samples during the 2-week studies and prior to and during the 3-month studies were $0.16 \%, 0.24 \%$, and $0.34 \%$ of the total peak areas, respectively; the presence of this impurity was attributed to artifacts of sample collection or formation in the injector port. Diethylamine was shown to be present at less than $0.1 \%$ in all samples from the generator reservoir. No evidence of degradation of the test chemical was detected, and no other impurities were detected in any of the reservoir, distribution line, or exposure chamber samples.

\section{Animal Welfare}

Animal care and use are in accordance with the Public Health Service policy on Humane Care and Use of Animals. All animal studies were conducted in an animal facility accredited by the Association of Laboratory Animal Care International. Studies were approved by the Battelle Toxicology Northwest Animal Care and Use Committee and conducted in accordance with all relevant NIH and NTP animal care and use policies and applicable federal, state, and local regulations and guidelines.

\section{Two-week Studies}

Male and female F344/N rats and B6C3F1/N mice were obtained from Taconic Farms, Inc. (Germantown, NY). On receipt, the rats and mice were 4 weeks old. Animals were quarantined for 13 days and were 6 weeks old on the first day of the studies. Groups of five male and five female rats and mice were exposed to triethylamine via whole body inhalation at concentrations of $0,100,200,400,800$, or $1,000 \mathrm{ppm}$. These exposure concentrations were based upon results reported for diethylamine inhalation studies conducted in mice ${ }^{41}$ and rats ${ }^{42}$. Animals were exposed for 6 hours plus T90 (12 minutes) per day, 5 days per week for 16 (rats) or 17 (mice) days. Rats were exposed for a total of 12 days and mice for 13 days. Feed was available 
ad libitum except during exposure periods; water was available ad libitum. Rats and mice were housed individually. Clinical findings were recorded twice daily for rats and mice. The animals were weighed initially, on days 6 and 13, and at the end of the studies. Before the studies began, five male and five female rats and mice were randomly selected for parasite evaluation and gross observation for evidence of disease. At the end of the studies, serologic analyses were performed on five male and five female chamber control rats and mice using the protocols of the NTP Sentinel Animal Program; all results were negative (Appendix H). Details of the study design and animal maintenance are summarized in Table 1.

Necropsies were performed on all rats and mice on the day following the last exposure. The heart, right kidney, liver, lung, right testis, and thymus were weighed. Histopathologic examinations were performed on all chamber control and 800 and 1,000 ppm rats and mice, and tissues were examined to a no-effect level in the remaining exposure groups. Table 1 lists the tissues and organs examined.

\section{Three-month Studies}

Male and female F344/N rats and B6C3F1/N mice were obtained from Taconic Farms, Inc. (Germantown, NY). On receipt, the rats and mice were 3 to 4 weeks old. Animals were quarantined for 12 (male rats and male and female mice) or 13 days (female rats) and were 5 to 6 weeks old on the first day of the studies. Before the studies began, five male and five female rats and mice were randomly selected for parasite evaluation and gross observation for evidence of disease. Serologic analyses were performed on five male and five female sentinel rats and mice at 2 weeks and on five male and five female chamber control rats and mice at the end of the studies using the protocols of the NTP Sentinel Animal Program; all results were negative (Appendix H).

Groups of 10 male and 10 female rats and mice were exposed to triethylamine via whole body inhalation at concentrations of $0,12.5,25,50,100$, or $200 \mathrm{ppm}, 6$ hours plus $\mathrm{T}_{90}$ (12 minutes) per day, 5 days per week for 14 weeks. Groups of 10 male and 10 female clinical pathology rats were exposed to the same concentrations for 23 days. Feed was available ad libitum except during exposure periods; water was available ad libitum. Rats and mice were housed individually. Clinical findings were recorded twice daily for core study rats and mice. Core study animals were weighed initially, on day 10 (female rats), day 11 (male rats and male and female mice), weekly thereafter, and at the end of the studies. Details of the study design and animal maintenance are summarized in Table 1.

Animals were anesthetized with carbon dioxide, and blood was collected from the retroorbital sinus of clinical pathology rats on days 3 and 23 and from core study rats and mice at the end of the studies for hematology and clinical chemistry (rats only) analyses. Blood samples for hematology analyses were placed in tubes containing potassium EDTA. Packed cell volume; hemoglobin concentration; erythrocyte, platelet, and leukocyte counts; mean cell volume; mean cell hemoglobin; and mean cell hemoglobin concentration were determined using an Abbott Cell-Dyn 3700 Analyzer (Abbott Diagnostics Systems, Abbott Park, IL). Manual hematocrit values were determined using a microcentrifuge (Heraeus Haemofuge; Hanau, Germany) and a Damon/IEC capillary reader (International Equipment Co., Needham Heights, MA) for comparison to Cell-Dyn values for packed cell volume. Blood smears were stained with Romanowsky-type aqueous stain in a Wescor 1700 aerospray slide stainer (Wescor, Inc., Logan, 
UT). Leukocyte differential counts were based on classifying a minimum of 100 white cells. Reticulocytes were stained with new methylene blue and enumerated as a reticulocyte:erythrocyte ratio using the Miller disc method ${ }^{43}$. Blood samples for clinical chemistry analyses were placed in tubes without anticoagulant and containing a separator gel, allowed to clot, and centrifuged. Parameters were determined using a Roche Hitachi 912 System (Roche Diagnostic Corporation, Indianapolis, IN). Table 1 lists the parameters measured.

At the end of the 3-month studies, samples were collected for sperm motility and vaginal cytology evaluations on rats and mice exposed to $0,50,100$, and $200 \mathrm{ppm}$. The parameters evaluated are listed in Table 1. For 12 consecutive days prior to scheduled terminal kill, the vaginal vaults of the females were moistened with saline, if necessary, and samples of vaginal fluid and cells were stained. Relative numbers of leukocytes, nucleated epithelial cells, and large squamous epithelial cells were determined and used to ascertain estrous cycle stage (i.e., diestrus, proestrus, estrus, and metestrus). Male animals were evaluated for sperm count and motility. The left testis and left epididymis were isolated and weighed. The tail of the epididymis (cauda epididymis) was then removed from the epididymal body (corpus epididymis) and weighed. Test yolk (rats) or modified Tyrode's buffer (mice) was applied to slides and a small incision was made at the distal border of the cauda epididymis. The sperm effluxing from the incision were dispersed in the buffer on the slides, and the numbers of motile and nonmotile spermatozoa were counted for five fields per slide by two observers. Following completion of sperm motility estimates, each left cauda epididymis was placed in buffered saline solution. Caudae were finely minced, and the tissue was incubated in the saline solution and then heat fixed at $65^{\circ} \mathrm{C}$. Sperm density was then determined microscopically with the aid of a hemacytometer. To quantify spermatogenesis, the testicular spermatid head count was determined by removing the tunica albuginea and homogenizing the left testis in phosphatebuffered saline containing 10\% dimethyl sulfoxide. Homogenization-resistant spermatid nuclei were counted with a hemacytometer.

Necropsies were performed on all animals. The heart, right kidney, liver, lung, right testis, and thymus were weighed. Tissues for microscopic examination were fixed and preserved in $10 \%$ neutral buffered formalin, processed and trimmed, embedded in paraffin, sectioned to a thickness of 4 to $6 \mu \mathrm{m}$, and stained with hematoxylin and eosin. Complete histopathologic examinations were performed by the study laboratory pathologist on all chamber control and $200 \mathrm{ppm}$ animals. In addition, the eyes, larynx, lung, nose, and trachea in the remaining groups of rats and mice, and the large intestine (cecum, colon, rectum), small intestine (duodenum, jejunum, ileum), kidney, liver, and stomach (forestomach and glandular) in the remaining groups of rats were examined. Table 1 lists the tissues and organs routinely examined.

After a review of the laboratory reports and selected histopathology slides by a quality assessment (QA) pathologist, the findings and reviewed slides were submitted to a NTP Pathology Peer Review (PPR) coordinator for a second independent review. Any inconsistencies in the diagnoses made by the study laboratory and QA pathologists were resolved by the NTP PPR process. Final diagnoses for reviewed lesions represent a consensus of the PPR or a consensus between the study laboratory pathologist, NTP pathologist, QA pathologist(s), and the PPR coordinator. Details of these review procedures have been described, in part, by Maronpot and Boorman ${ }^{44}$ and Boorman et al. $^{45}$. Because of the demise of the original NTP pathologist prior to completion of the Toxicity Study Report and the development of the Nonneoplastic Lesion Atlas (NNLA), a second NTP pathologist was assigned to this study to equate the 
terminology used in the current Toxicity Study Report to that recommended in the NNLA. As a result, three additional PPRs were performed to assess the nasoturbinates of the 3-month mice, the eyes of the 2-week rats and mice, and the eyes of 3-month rats. The recommendations of those PPRs were then incorporated into the final diagnoses used in this Toxicity Study Report.

Table 1. Experimental Design and Materials and Methods in the Inhalation Studies of Triethylamine

\section{Two-week Studies}

\section{Study Laboratory}

Battelle Toxicology Northwest (Richland, WA)

\section{Strain and Species}

F344/N rats

B6C3F1/N mice

Animal Source

Taconic Farms, Inc. (Germantown, NY)

\section{Time Held Before Studies}

13 days

\section{Average Age When Studies Began}

6 weeks

\section{Date of First Exposure}

September 23, 2002

\section{Duration of Exposure}

6 hours plus $\mathrm{T}_{90}$ (12 minutes) per day, 5 days per week, for 16 (rats) or 17 (mice) days

\section{Date of Last Exposure}

Rats: October 8, 2002

Mice: October 9, 2002

\section{Necropsy Dates}

Rats: October 9, 2002

Mice: October 10, 2002

\section{Average Age at Necropsy}

8 weeks

Size of Study Groups

5 males and 5 females

\section{Method of Distribution}

Animals were distributed randomly into groups of approximately equal initial mean body weights.
Battelle Toxicology Northwest (Richland, WA)

F344/N rats

$\mathrm{B} 6 \mathrm{C} 3 \mathrm{~F} 1 / \mathrm{N}$ mice

Taconic Farms, Inc. (Germantown, NY)

Rats: 12 days (males) or 13 days (females)

Mice: 12 days

5 to 6 weeks

Rats: January 20 (males) or 21 (females), 2003

Mice: January 20, 2003

6 hours plus $\mathrm{T}_{90}$ (12 minutes) per day, 5 days per week, for 14 weeks

Rats: April 21 (males) or 22 (females), 2003

Mice: April 23 (males) or 24 (females), 2003

Rats: April 22 (males) or 23 (females), 2003

Mice: April 24 (males) or 25 (females), 2003

18 to 19 weeks

10 males and 10 females

Same as 2-week studies 


\begin{tabular}{l} 
Two-week Studies \\
\hline Animals per Cage \\
1
\end{tabular}

\section{Method of Animal Identification}

Tail tattoo

Same as 2-week studies

\section{Diet}

NTP-2000 irradiated wafers (Zeigler Brothers, Inc., Gardners, PA), available ad libitum (except during exposure periods); changed weekly

\section{Water}

Tap water (Richland, WA, municipal supply) via automatic watering system (Edstrom Industries, Waterford, WI); available ad libitum

\section{1}

\section{Cages}

Stainless steel, wire bottom (Lab Products, Inc., Seaford, Same as 2-week studies; rotated weekly DE); changed weekly

\section{Cageboard}

Untreated paper cage pan liner (Sheperd Specialty Papers, Kalamazoo, MI), changed daily

Same as 2-week studies

\section{Chamber Air Supply Filters}

Single HEPA, changed annually; charcoal (RSE, Inc., Same as 2-week studies New Baltimore, MI), new at study start; Purafil (Environmental Systems, Lynnwood, WA), new at study start

\section{Chambers}

Stainless steel, excreta pan at each of six levels (Lab Same as 2-week studies Products, Inc., Seaford, DE); chambers changed weekly; excreta pans changed daily

\section{Chamber Environment}

Temperature: $72^{\circ} \pm 3^{\circ} \mathrm{F}$ Same as 2-week studies

Relative humidity: $50 \% \pm 15 \%$

Room fluorescent light: 12 hours/day

Chamber air changes: $15 \pm 2$ /hour

\section{Exposure Concentrations}

0, 100, 200, 400, 800, and 1,000 ppm

$0,12.5,25,50,100$, and $200 \mathrm{ppm}$

\section{Type and Frequency of Observation}

Observed twice daily; animals were weighed initially, on days 6 and 13, and at the end of the studies; clinical findings were recorded twice daily on exposure days.

Observed twice daily; core study animals were weighed initially, on day 10 (female rats), day 11 (male rats and male and female mice), weekly thereafter, and at the end of the studies; clinical findings were recorded twice daily. 
Triethylamine, NTP TOX 78

\section{Two-week Studies}

Three-month Studies

Method of Kill

Carbon dioxide asphyxiation

Necropsy

Necropsies were performed on all animals. Organs weighed were heart, right kidney, liver, lung, right testis, and thymus.

\section{Clinical Pathology}

None

\section{Histopathology}

Histopathology was performed on 0,800 , and $1,000 \mathrm{ppm}$ rats and mice. In addition to gross lesions and tissue masses, the following tissues were examined: eye, lung, and nose. In mice, these tissues were examined to a no-effect level in the remaining exposure groups.
Same as 2-week studies

Necropsies were performed on all animals. Organs weighed were heart, right kidney, liver, lung, right testis, and thymus.

Blood was collected from the retroorbital sinus of clinical pathology rats on days 3 and 23 and from core study animals at the end of the studies for hematology and clinical chemistry (rats only).

Hematology: hematocrit; packed cell volume; hemoglobin; erythrocyte, reticulocyte, and platelet counts; Howell-Jolly bodies (mice); mean cell volume; mean cell hemoglobin; mean cell hemoglobin concentration; and leukocyte counts and differentials.

Clinical chemistry: urea nitrogen, creatinine, total protein, albumin, globulin, alanine aminotransferase, alkaline phosphatase, creatine kinase, sorbitol dehydrogenase, and bile salts

Complete histopathology was performed on 0 and $200 \mathrm{ppm}$ core study rats and mice. In addition to gross lesions and tissue masses, the following tissues were examined: adrenal gland, bone with marrow, brain, clitoral gland, esophagus, eyes, gallbladder (mice), Harderian gland, heart and aorta, large intestine (cecum, colon, rectum), small intestine (duodenum, jejunum, ileum), kidney, larynx, liver, lung (with bronchus), lymph nodes (mandibular, mesenteric, bronchial, mediastinal), mammary gland, nose, ovary, pancreas, parathyroid gland, pituitary gland, preputial gland, prostate gland, salivary gland, seminal vesicle, skin, spleen, stomach (forestomach and glandular), testis (with epididymis), thymus, thyroid gland, trachea, urinary bladder, and uterus. In addition, the eyes, larynx, lung, nose, and trachea in the remaining groups of rats and mice, and the large intestine (cecum, colon, rectum), small intestine (duodenum, jejunum, ileum), kidney, liver, and stomach (forestomach and glandular) in the remaining groups of rats were examined. 


\section{Statistical Methods}

\section{Calculation and Analysis of Lesion Incidences}

The incidences of lesions are presented in Appendix A as the numbers of animals bearing such lesions at a specific anatomic site and the numbers of animals with that site examined microscopically. The Fisher exact test ${ }^{46}$, a procedure based on the overall proportion of affected animals, was used to determine significance.

\section{Analysis of Continuous Variables}

Two approaches were employed to assess the significance of pairwise comparisons between exposed and control groups in the analysis of continuous variables. Organ and body weight data, which historically have approximately normal distributions, were analyzed with the parametric multiple comparison procedures of Dunnett ${ }^{47}$ and Williams ${ }^{48 ; 49}$. Hematology, clinical chemistry, spermatid, and epididymal spermatozoal data, which have typically skewed distributions, were analyzed using the nonparametric multiple comparison methods of Shirley ${ }^{50}$ (as modified by Williams ${ }^{51}$ ) and Dunn ${ }^{52}$. Jonckheere's test ${ }^{53}$ was used to assess the significance of the doserelated trends and to determine whether a trend-sensitive test (Williams' or Shirley's test) was more appropriate for pairwise comparisons than a test that does not assume a monotonic doserelated trend (Dunnett's or Dunn's test). Prior to statistical analysis, extreme values identified by the outlier test of Dixon and Massey ${ }^{54}$ were examined by NTP personnel, and implausible values were eliminated from the analysis. Proportions of regular cycling females in each exposed group were compared to the control group using the Dunn's test ${ }^{52}$. Tests for extended periods of estrus, diestrus, metestrus, and proestrus, as well as skipped estrus and skipped diestrus were constructed based on a Markov chain model proposed by Girard and Sager ${ }^{55}$. For each exposure group, a transition probability matrix was estimated for transitions among the proestrus, estrus, metestrus, and diestrus stages, with provision for extended stays within each stage as well as for skipping estrus or diestrus within a cycle. Equality of transition matrices among exposure groups and between the control group and each exposed group was tested using chi-square statistics. 


\section{Quality Assurance Methods}

The 2-week and 3-month studies were conducted in compliance with Food and Drug Administration Good Laboratory Practice Regulations ${ }^{56}$.

\section{Genetic Toxicology}

\section{Bacterial Mutagenicity Test Protocol}

Testing was performed as reported by Zeiger et al. ${ }^{39}$. Triethylamine was sent to the laboratory as a coded aliquot from Radian Corporation (Austin, TX). It was incubated with the Salmonella typhimurium tester strains TA98, TA100, TA1535, and TA1537 either in buffer or S9 mix (metabolic activation enzymes and cofactors from Aroclor 1254-induced male Sprague-Dawley rat or Syrian hamster liver) for 20 minutes at $37^{\circ} \mathrm{C}$. Top agar supplemented with L-histidine and d-biotin was added, and the contents of the tubes were mixed and poured onto the surfaces of minimal glucose agar plates. Histidine-independent mutant colonies arising on these plates were counted following incubation for 2 days at $37^{\circ} \mathrm{C}$.

Each trial consisted of triplicate plates of concurrent positive and negative controls and five doses of triethylamine. The high dose was $10,000 \mu \mathrm{g} /$ plate, which induced toxicity in some trials. All trials were repeated.

In this assay, a positive response is defined as a reproducible, dose-related increase in histidineindependent (revertant) colonies in any one strain/activation combination. An equivocal response is defined as an increase in revertants that is not dose related, is not reproducible, or is not of sufficient magnitude to support a determination of mutagenicity. A negative response is obtained when no increase in revertant colonies is observed following chemical treatment. There is no minimum percentage or fold increase required for a chemical to be judged positive or weakly positive, although positive calls are typically reserved for increases in mutant colonies that are at least twofold over background.

\section{Mouse Peripheral Blood Micronucleus Test Protocol}

A detailed discussion of this assay is presented by MacGregor et al. ${ }^{57}$. At the end of the 3-month toxicity study, peripheral blood samples were obtained from male and female mice. Smears were immediately prepared and fixed in absolute methanol. The methanol-fixed slides were stained with acridine orange and coded. Slides were scanned to determine the frequency of micronuclei in 1,000 normochromatic erythrocytes (NCEs) in each of 10 animals per exposure group. In addition, the percentage of polychromatic erythrocytes (PCEs) among a population of 1,000 erythrocytes was scored for each exposure group as a measure of bone marrow toxicity.

The results were tabulated as the mean of the pooled results from all animals within a treatment group plus or minus the standard error of the mean. The frequency of micronucleated cells among NCEs was analyzed by a statistical software package that tested for increasing trend over exposure groups with a one-tail Cochran-Armitage trend test, followed by pairwise comparisons between each exposed group and the control group. In the presence of excess binomial variation, as detected by a binomial dispersion test, the binomial variance of the Cochran-Armitage test was adjusted upward in proportion to the excess variation. In the micronucleus test, an individual trial is considered positive if the trend test $\mathrm{P}$ value is less than or equal to 0.025 or if the $\mathrm{P}$ value 
for any single exposed group is less than or equal to 0.025 divided by the number of exposed groups. A final call of positive for micronucleus induction is preferably based on reproducibly positive trials (as noted above). Ultimately, the final call is determined by the scientific staff after considering the results of statistical analyses, the reproducibility of any effects observed, and the magnitudes of those effects.

\section{Evaluation Protocol}

These are the basic guidelines for arriving at an overall assay result for assays performed by the National Toxicology Program. Statistical as well as biological factors are considered. For an individual assay, the statistical procedures for data analysis have been described in the preceding protocols. There have been instances, however, in which multiple samples of a chemical were tested in the same assay, and different results were obtained among these samples and/or among laboratories. Results from more than one aliquot or from more than one laboratory are not simply combined into an overall result. Rather, all the data are critically evaluated, particularly with regard to pertinent protocol variations, in determining the weight of evidence for an overall conclusion of chemical activity in an assay. In addition to multiple aliquots, the in vitro assays have another variable that must be considered in arriving at an overall test result. In vitro assays are conducted with and without exogenous metabolic activation. Results obtained in the absence of activation are not combined with results obtained in the presence of activation; each testing condition is evaluated separately. The results presented in the Abstract of this Toxicity Study Report represent a scientific judgment of the overall evidence for activity of the chemical in an assay. 


\section{Results}

\section{Rats}

\section{Two-week Study}

Rats exposed to 800 or 1,000 ppm triethylamine died after the first exposure on day 1 (Table 2). Final mean body weights of all surviving exposed male rats and the 200 and 400 ppm female rats were significantly less than those of the chamber controls; mean body weight gains were significantly less in all surviving groups. In addition to ataxia and tremors that were observed initially on day 1 , lethargy, abnormal breathing, and nasal discharge were observed throughout the study in the 400 ppm rats. Abnormal breathing was observed in all 400 ppm males and females at the end of the study. Nasal discharge (one male and one female) and lethargy (all male and female rats) were observed only on the first 2 days of exposure to $200 \mathrm{ppm}$.

Table 2. Survival and Body Weights of Rats in the Two-week Inhalation Study of Triethylamine ${ }^{\mathrm{a}}$

\begin{tabular}{cccccc}
\hline $\begin{array}{c}\text { Concentration } \\
(\mathbf{p p m})\end{array}$ & Survival $^{\mathbf{b}}$ & $\begin{array}{c}\text { Initial Body } \\
\text { Weight } \\
(\mathbf{g})\end{array}$ & $\begin{array}{c}\text { Final Body } \\
\text { Weight } \\
(\mathbf{g})\end{array}$ & $\begin{array}{c}\text { Change in Body } \\
\text { Weight } \\
(\mathbf{g})\end{array}$ & $\begin{array}{c}\text { Final Weight } \\
\text { Relative to } \\
\text { Controls } \\
(\boldsymbol{\%})\end{array}$ \\
\hline Male & & & & & \\
0 & $5 / 5$ & $102 \pm 2$ & $170 \pm 4$ & $68 \pm 3$ & \\
100 & $5 / 5$ & $100 \pm 3$ & $159 \pm 4^{*}$ & $59 \pm 2^{*}$ & 94 \\
200 & $5 / 5$ & $102 \pm 2$ & $152 \pm 3^{* *}$ & $49 \pm 2^{* *}$ & 89 \\
400 & $5 / 5$ & $101 \pm 2$ & $120 \pm 3^{* *}$ & $19 \pm 2^{* *}$ & 70 \\
800 & $0 / 5^{\mathrm{c}}$ & $102 \pm 2$ & - & - & - \\
1,000 & $0 / 5^{\mathrm{c}}$ & $101 \pm 3$ & - & - & - \\
\hline
\end{tabular}

Female

$\begin{array}{cccccc}0 & 5 / 5 & 89 \pm 2 & 128 \pm 2 & 39 \pm 1 & \\ 100 & 5 / 5 & 91 \pm 1 & 125 \pm 2 & 35 \pm 1^{*} & 98 \\ 200 & 5 / 5 & 89 \pm 2 & 117 \pm 3^{* *} & 28 \pm 2^{* *} & 91 \\ 400 & 5 / 5 & 89 \pm 2 & 103 \pm 3^{* *} & 14 \pm 2^{* *} & 80 \\ 800 & 0 / 5^{\mathrm{c}} & 89 \pm 1 & - & - & - \\ 1,000 & 0 / 5^{\mathrm{c}} & 87 \pm 2 & - & - & -\end{array}$

*Significantly different $(\mathrm{P} \leq 0.05)$ from the chamber control group by Williams' test.

$* * \mathrm{P} \leq 0.01$.

${ }^{a}$ Weights and weight changes are given as mean \pm standard error. Subsequent calculations are based on animals surviving to the end of the study.

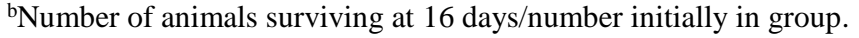

'Day of deaths: 1 .

The absolute and relative kidney weights of $100 \mathrm{ppm}$ females and the relative kidney weights of 200 and $400 \mathrm{ppm}$ males and females were significantly greater than those of the chamber controls (Table D-1). Because there was no histopathologic evidence of kidney toxicity at any concentration, the higher relative kidney weights were considered secondary to the significantly 
lower body weights (30\% in males, $20 \%$ in females). Absolute weights of the heart and liver in all surviving male exposed groups were significantly lower than those of the chamber controls. The absolute and relative right testis and thymus weights and absolute right kidney weight of $400 \mathrm{ppm}$ males and the absolute and relative thymus weights of $400 \mathrm{ppm}$ females were also significantly lower than those of the chamber controls. Lower absolute organ weights were considered to be secondary to decreased body weights.

At necropsy, gastric dilatation due to forced mouth breathing was observed in rats that died early and a few rats had lung lesions. Gastric dilatation is commonly observed in animals with nasal toxicity resulting in occluded or partially occluded nasal airflow.

All 800 and 1,000 ppm rats died early and had marked necrosis of the respiratory and olfactory epithelium of the nose and the bronchial epithelium of the lung, as well as corneal epithelial vacuolation and sometimes corneal necrosis (Table 3).

In the nose, there were significantly increased incidences of respiratory epithelium hyperplasia in all surviving groups of exposed males (Table 3); turbinate necrosis, squamous metaplasia of the respiratory epithelium, suppurative inflammation, and respiratory epithelium ulcer in $400 \mathrm{ppm}$ males; and suppurative inflammation and olfactory epithelium atrophy in $200 \mathrm{ppm}$ males. In $400 \mathrm{ppm}$ females, there were significantly increased incidences of suppurative inflammation, squamous metaplasia of the respiratory epithelium, and respiratory epithelium ulcer. There were also significantly increased incidences of respiratory epithelium hyperplasia in 100 and $200 \mathrm{ppm}$ females, and olfactory epithelium atrophy in $200 \mathrm{ppm}$ females. In both sexes, the severities of these lesions were generally greater at $400 \mathrm{ppm}$ than in the lower exposure concentration groups.

Microscopically, lesions in the nose occurred most frequently in nasal sections of Level I and to a lesser extent in the dorsal meatus of Level II. Minimal to marked multifocal ulcers of the respiratory epithelium were accompanied by minimal to marked suppurative inflammation, mild to moderate squamous metaplasia, and minimal to mild respiratory cell hyperplasia with moderate necrosis of the turbinate bone underlying ulcers in $400 \mathrm{ppm}$ rats. Lesions were generally less severe in the 100 and $200 \mathrm{ppm}$ groups. Ulcers of the respiratory epithelium were multiple and resulted from localized loss of the mucosal epithelium down to the lamina propria. These ulcers were accompanied by suppurative inflammation with accumulations of neutrophils in the lamina propria. There was replacement of some normal columnar cells by squamous cells. Often the adjacent respiratory epithelium was thickened and hypercellular. Necrosis of the lateral hooks of the nasoturbinates in Level I was characterized by thinning of the bone, irregular scalloped borders due to resorption, fragmentation, and absence of osteocytes and bone lining cells. Minimal to moderate olfactory epithelium atrophy was observed in the dorsal meatus of Level II in all surviving male and female groups. In olfactory epithelial atrophy, there was a loss of cilia, altered orientation of affected cells, and decreased numbers of epithelial cells that resulted in thinning of the normal pseudostratified columnar cells. 
Table 3. Incidences of Selected Nonneoplastic Lesions in Rats in the Two-week Inhalation Study of Triethylamine

\begin{tabular}{|c|c|c|c|c|c|c|}
\hline & $\begin{array}{l}\text { Chamber } \\
\text { Control }\end{array}$ & 100 ppm & 200 ppm & 400 ppm & 800 ppm & 1,000 ppm \\
\hline \multicolumn{7}{|l|}{ Male } \\
\hline Nose $^{a}$ & 5 & 5 & 5 & 5 & 5 & 5 \\
\hline Inflammation, Suppurative ${ }^{b}$ & 0 & $1(1.0)^{\mathrm{c}}$ & $4 *(1.3)$ & $5 * *(3.0)$ & 0 & 0 \\
\hline Olfactory Epithelium, Atrophy & 0 & $3(1.0)$ & $4 *(1.0)$ & $3(1.7)$ & 0 & 0 \\
\hline $\begin{array}{l}\text { Olfactory Epithelium, } \\
\text { Respiratory Epithelium } \\
\text { Necrosis }\end{array}$ & 0 & 0 & 0 & 0 & $5 * *(4.0)$ & $5 * *(4.0)$ \\
\hline $\begin{array}{l}\text { Respiratory Epithelium, } \\
\text { Hyperplasia }\end{array}$ & 0 & $4 *(1.0)$ & $5 * *(1.2)$ & $5 * *(1.6)$ & 0 & 0 \\
\hline $\begin{array}{l}\text { Respiratory Epithelium, } \\
\text { Metaplasia, Squamous }\end{array}$ & 0 & 0 & $2(1.0)$ & $5 * *(2.0)$ & 0 & 0 \\
\hline Respiratory Epithelium, Ulcer & 0 & 0 & 0 & $5 * *(3.2)$ & 0 & 0 \\
\hline Turbinate, Necrosis & 0 & 0 & 0 & $4 *(3.0)$ & 0 & 0 \\
\hline Lung & 5 & 5 & 5 & 5 & 5 & 5 \\
\hline Bronchus, Degeneration & 0 & 0 & $4 *(1.3)$ & $5 * *(2.6)$ & 0 & 0 \\
\hline $\begin{array}{l}\text { Bronchus, Inflammation, } \\
\text { Suppurative }\end{array}$ & 0 & 0 & 0 & $5 * *(2.2)$ & 0 & 0 \\
\hline Bronchus, Necrosis & 0 & 0 & 0 & 0 & $5 * *(4.0)$ & $5 * *(4.0)$ \\
\hline Bronchus, Regeneration & 0 & 0 & 0 & $5 * *(3.4)$ & 0 & 0 \\
\hline \multicolumn{7}{|l|}{ Female } \\
\hline Nose & 5 & 5 & 5 & 5 & 5 & 5 \\
\hline Inflammation, Suppurative & 0 & $1(1.0)$ & $1(1.0)$ & $5 * *(3.4)$ & 0 & 0 \\
\hline Olfactory Epithelium, Atrophy & 0 & $2(1.0)$ & $4 *(1.0)$ & $3(1.0)$ & 0 & 0 \\
\hline $\begin{array}{l}\text { Olfactory Epithelium, } \\
\text { Respiratory Epithelium, } \\
\text { Necrosis }\end{array}$ & 0 & 0 & 0 & 0 & $5 * *(4.0)$ & $5 * *(4.0)$ \\
\hline $\begin{array}{l}\text { Respiratory Epithelium, } \\
\text { Hyperplasia }\end{array}$ & 0 & $4 *(1.0)$ & $4 *(1.0)$ & $3(1.0)$ & 0 & 0 \\
\hline $\begin{array}{l}\text { Respiratory Epithelium, } \\
\text { Metaplasia, Squamous }\end{array}$ & 0 & 0 & 0 & $5 * *(2.2)$ & 0 & 0 \\
\hline Respiratory Epithelium, Ulcer & 0 & 0 & 0 & $4 *(2.5)$ & 0 & 0 \\
\hline Turbinate, Necrosis & 0 & 0 & 0 & $3(3.0)$ & 0 & 0 \\
\hline Lung & 5 & 5 & 5 & 5 & 5 & 5 \\
\hline Bronchus, Degeneration & 0 & 0 & $4 *(1.0)$ & $5 * *(2.8)$ & 0 & 0 \\
\hline $\begin{array}{l}\text { Bronchus, Inflammation, } \\
\text { Suppurative }\end{array}$ & 0 & 0 & 0 & $5 * *(2.0)$ & 0 & 0 \\
\hline Bronchus, Necrosis & 0 & 0 & 0 & 0 & $5 * *(4.0)$ & $5 * *(4.0)$ \\
\hline
\end{tabular}




\begin{tabular}{lcccccc}
\hline & $\begin{array}{c}\text { Chamber } \\
\text { Control }\end{array}$ & $\mathbf{1 0 0} \mathbf{~ p p m}$ & $\mathbf{2 0 0} \mathbf{~ p p m}$ & $\mathbf{4 0 0} \mathbf{~ p p m}$ & $\mathbf{8 0 0} \mathbf{~ p p m}$ & $\mathbf{1 , 0 0 0} \mathbf{~ p p m}$ \\
\hline Bronchus, Regeneration & 0 & 0 & 0 & $5^{* *}(2.8)$ & 0 & 0
\end{tabular}

*Significantly different $(\mathrm{P} \leq 0.05)$ from the chamber control group by the Fisher exact test. $* * \mathrm{P} \leq 0.01$.

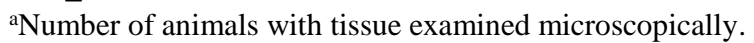

${ }^{b}$ Number of animals with lesion.

${ }^{\mathrm{c}}$ Average severity grade of lesions in affected animals: $1=$ minimal, $2=$ mild, $3=$ moderate, $4=$ marked.

In the lung, there were significantly increased incidences of bronchus degeneration in 200 and $400 \mathrm{ppm}$ males and females and suppurative inflammation and bronchus regeneration in $400 \mathrm{ppm}$ groups (Table 3). The severity of bronchus degeneration was greatest in the $400 \mathrm{ppm}$ groups. Microscopically, minimal to moderate bronchus degeneration consisted of a loss of cilia and flattening of the bronchial epithelium. Mild to marked bronchus regeneration consisted of piling up and rounding of the bronchial epithelial cells.

In the eye, vacuolation (microvacuolar degeneration) of the corneal epithelium was noted in the 800 and 1,000 ppm males and females (Table 4 and Figure 4). In addition, in four males and one female, the central corneal epithelium was absent, which appeared to be secondary to marked vacuolar degeneration of the basal layer cells resulting in detachment from the underlying stroma. Although the possibility that autolysis could have contributed to these changes cannot be completely excluded, the severity of the associated vacuolar degenerative changes and the foci of residual necrosis were considered by the Pathology Peer Review (PPR) panel to be more consistent with epithelial loss (ulcer) due to the chemical effect than to the autolysis. In addition, necrosis of the medial portion of the iris and degeneration of peripheral fibers of the lens (cataracts) were noted in some of the 800 and $1,000 \mathrm{ppm}$ rats. In the rats exposed to $400 \mathrm{ppm}$ or less, all changes in the eyes were much milder, and included subepithelial vesicles of the cornea in a few animals in the 100,200, and 400 ppm groups, sometimes accompanied by scattered apoptotic or necrotic cells. 
Table 4. Incidences of Nonneoplastic Lesions of the Eye in Rats in the Two-week Inhalation Study of Triethylamine

\begin{tabular}{lcccccc}
\hline & $\begin{array}{c}\text { Chamber } \\
\text { Control }\end{array}$ & $\mathbf{1 0 0} \mathbf{~ p p m}$ & $\mathbf{2 0 0} \mathbf{~ p p m}$ & $\mathbf{4 0 0} \mathbf{~ p p m}$ & $\mathbf{8 0 0} \mathbf{~ p p m}$ & $\mathbf{1 , 0 0 0} \mathbf{~ p p m}$ \\
\hline Male & & & & & & \\
Number Examined Microscopically & 5 & 5 & 5 & 4 & 5 & 5 \\
$\quad$ Cornea, Epithelium, Ulcer & 0 & 0 & 0 & 0 & $3(2.3)^{\mathrm{b}}$ & $4^{*}(2.5)$ \\
Cornea, Epithelium, Vacuolation & 0 & 0 & 0 & 0 & $5^{* *(3.6)}$ & $5^{* *(2.8)}$ \\
Cornea, Necrosis & 0 & 0 & $1(1.0)$ & 0 & $5^{* *(1.6)}$ & $4^{*}(1.3)$ \\
Cornea, Vesicle, Subepithelial & 0 & 1 & 2 & 0 & 1 & 0 \\
Iris, Necrosis & 0 & 0 & 0 & 0 & $2(2.0)$ & $3(1.7)$ \\
Lens, Cataract & 0 & 0 & 0 & 0 & $1(1.0)$ & $2(1.0)$ \\
\hline Female & & & & & 5 & 5 \\
Number Examined Microscopically & 5 & 5 & 5 & 5 & 5 & $1(3.0)$ \\
Cornea, Epithelium, Ulcer & 0 & 0 & 0 & 0 & 0 & $4 *(2.8)$ \\
Cornea, Epithelium, Vacuolation & 0 & 0 & 0 & 0 & $4 *(3.3)$ & $4(1.0)$ \\
Cornea, Necrosis & 0 & $1(1.0)$ & $1(1.0)$ & 0 & $1(3.0)$ & $1(2.0)$ \\
Cornea, Vesicle, Subepithelial & 0 & 2 & 2 & 2 & 0 & 0 \\
Iris, Necrosis & 0 & 0 & 0 & 0 & $1(2.0)$ & 0 \\
Lens, Cataract & 0 & 0 & 0 & 0 & $1(2.0)$ & $1(2.0)$ \\
\hline
\end{tabular}

*Significantly different $(\mathrm{P} \leq 0.05)$ from the chamber control group by the Fisher exact test.

$* * \mathrm{P} \leq 0.01$.

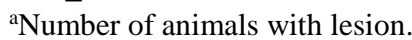

${ }^{\mathrm{b}}$ Average severity grade of lesions in affected animals: $1=$ minimal, $2=$ mild, $3=$ moderate, $4=$ marked.

Exposure concentration selection rationale: Exposure to concentrations of 800 and 1,000 ppm resulted in decreased survival. Exposure to $400 \mathrm{ppm}$ resulted in decreased body weights (20\% to $30 \%$ ), decreased organ weights, and moderate histopathologic changes in the nose of male and female rats. The effects on body weight and the nasal cavity were less severe in groups exposed to $200 \mathrm{ppm}$ or less. Therefore, exposure concentrations of $0,12.5,25,50,100$, and $200 \mathrm{ppm}$ triethylamine were selected for the 3-month study.

\section{Three-month Study}

All rats survived to the end of the study (Table 5). The final mean body weights and body weight gains of males and females exposed to $200 \mathrm{ppm}$ were significantly less than those of the chamber controls (Table 5; Figure 2). Abnormal breathing and thinness were noted in one $100 \mathrm{ppm}$ female; no other chemical-related clinical findings were observed. 
Triethylamine, NTP TOX 78

Table 5. Survival and Body Weights of Rats in the Three-month Inhalation Study of Triethylamine

\begin{tabular}{|c|c|c|c|c|c|}
\hline Concentration (ppm) & Survival $^{b}$ & $\begin{array}{c}\text { Initial Body } \\
\text { Weight } \\
\text { (g) }\end{array}$ & $\begin{array}{c}\text { Final Body } \\
\text { Weight } \\
\text { (g) }\end{array}$ & $\begin{array}{c}\text { Change in } \\
\text { Body Weight } \\
\text { (g) }\end{array}$ & $\begin{array}{c}\text { Final Weight } \\
\text { Relative to } \\
\text { Controls } \\
(\%)\end{array}$ \\
\hline \multicolumn{6}{|l|}{ Male } \\
\hline 0 & $10 / 10$ & $107 \pm 4$ & $347 \pm 7$ & $240 \pm 6$ & \\
\hline 12.5 & $10 / 10$ & $107 \pm 3$ & $360 \pm 8$ & $253 \pm 7$ & 104 \\
\hline 25 & $10 / 10$ & $108 \pm 3$ & $343 \pm 9$ & $235 \pm 7$ & 99 \\
\hline 50 & $10 / 10$ & $109 \pm 5$ & $352 \pm 8$ & $243 \pm 7$ & 101 \\
\hline 100 & $10 / 10$ & $108 \pm 4$ & $338 \pm 4$ & $230 \pm 5$ & 97 \\
\hline 200 & $10 / 10$ & $107 \pm 4$ & $300 \pm 5^{* *}$ & $193 \pm 5^{* *}$ & 87 \\
\hline \multicolumn{6}{|l|}{ Female } \\
\hline 0 & $10 / 10$ & $91 \pm 3$ & $209 \pm 4$ & $117 \pm 4$ & \\
\hline 12.5 & $10 / 10$ & $90 \pm 3$ & $211 \pm 4$ & $120 \pm 4$ & 101 \\
\hline 25 & $10 / 10$ & $91 \pm 2$ & $204 \pm 3$ & $113 \pm 2$ & 98 \\
\hline 50 & $10 / 10$ & $92 \pm 3$ & $207 \pm 5$ & $115 \pm 4$ & 99 \\
\hline 100 & $10 / 10$ & $91 \pm 3$ & $198 \pm 5$ & $107 \pm 5$ & 95 \\
\hline 200 & $10 / 10$ & $92 \pm 2$ & $181 \pm 3^{* *}$ & $89 \pm 3 * *$ & 87 \\
\hline
\end{tabular}

**Significantly different $(\mathrm{P} \leq 0.01)$ from the chamber control group by Williams' test.

${ }^{a}$ Weights and weight changes are given as mean \pm standard error.

${ }^{b}$ Number of animals surviving at 14 weeks/number initially in group. 

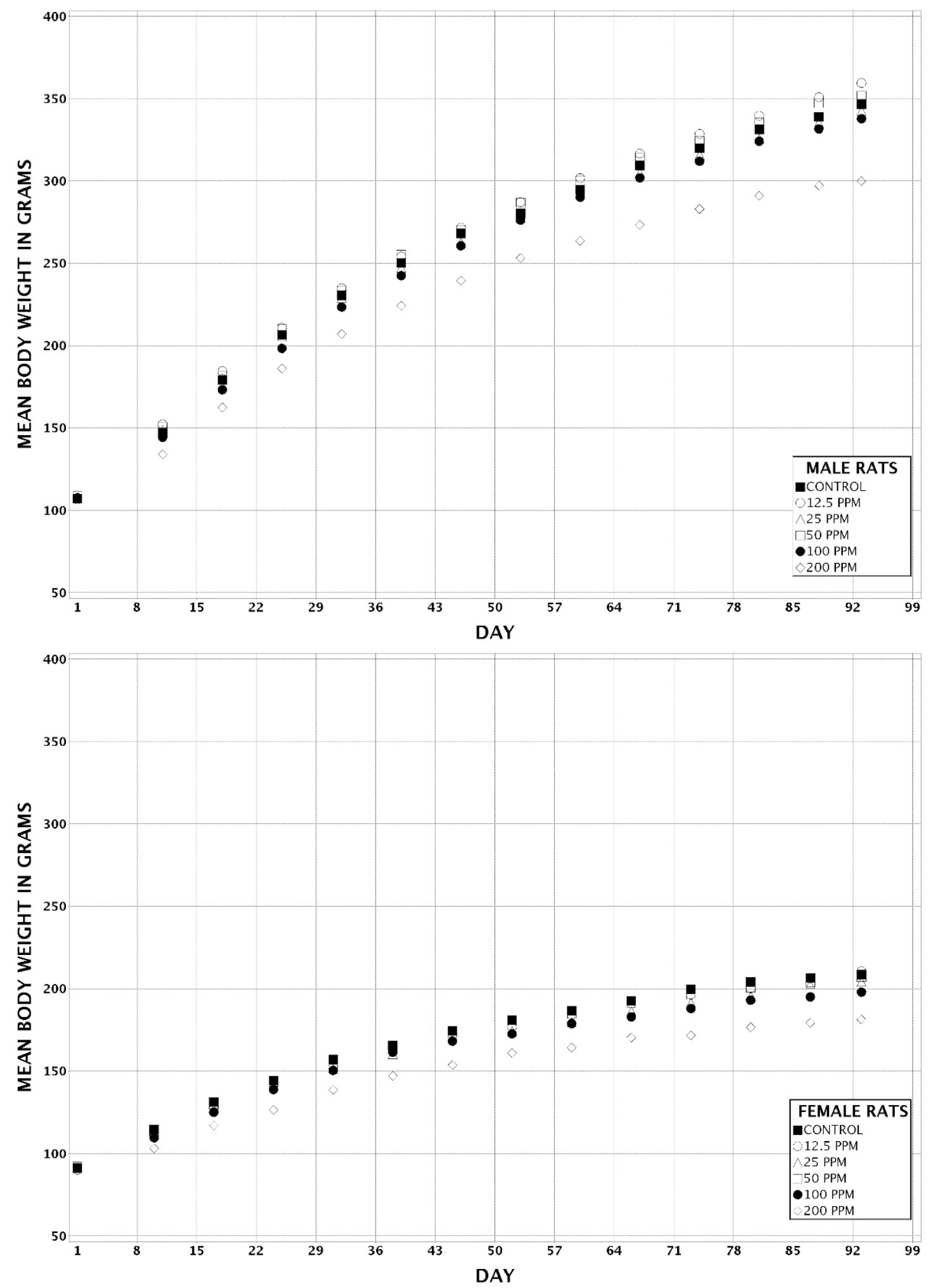

Figure 2. Growth Curves for Rats Exposed to Triethylamine by Inhalation for Three Months

There were no changes in the hematology endpoints that would be considered toxicologically relevant to triethylamine exposure (Table $\mathrm{C}-1)$. At day 3 in male and female rats exposed to 
$25 \mathrm{ppm}$ or greater, there appeared to be a transient decrease in white blood cell numbers involving lymphocytes and eosinophils, which generally disappeared by day 23 . The relevance of this transient leukocyte response to the potential toxicity of triethylamine is questionable. There were small $(<15 \%)$ decreases in albumin, globulin, and total protein concentrations in males and females exposed to 100 or $200 \mathrm{ppm}$. This decrease in protein occurred only at week 14 and may have been related to the lower mean body weights.

The absolute heart, liver, lung, and thymus weights of 200 ppm males and the absolute heart, liver, and thymus weights of $200 \mathrm{ppm}$ females were significantly less than those of the chamber control groups (Table D-2). The changes were considered to be related to decreased body weights.

Slight decreases in epididymal sperm motility were observed in 50, 100, and 200 ppm males (3\%, $4 \%$, and $6 \%$, respectively, compared to chamber controls) and slight increases (10\%) in the number of spermatid heads per mg testis were observed in 100 and 200 ppm males (Table E-1). Although exposed female rats exhibited a slight tendency towards increased amounts of time spent in metestrus, the increases were not significant and the number of cycling females, number of females with irregular cycles, and the lengths and numbers of the estrous cycles were similar to those of the chamber controls (Table E-2 and Table E-3; Figure 2).

In the olfactory epithelium of the nose, there were significantly increased incidences of atrophy in males exposed to $50 \mathrm{ppm}$ or greater and in females exposed to $25 \mathrm{ppm}$ or greater (Table 6 , Table A-1, and Table A-2). In the respiratory epithelium of the nose, there were significantly increased incidences of hyperplasia in males and females exposed to $25 \mathrm{ppm}$ or greater. The severities of these nasal lesions generally increased with increasing exposure concentration.

Microscopically, olfactory epithelium atrophy was a minimal to moderate change affecting the dorsal meatus in nasal section Level II of the nose and in more severe cases the dorsal meatus and septum in Level III. This atrophy was characterized by varying degrees of loss of olfactory sensory neurons from the epithelium, and decreases in nerve bundles and Bowman's glands in the lamina propria. The affected epithelium was hypocellular and reduced in height. Small, ovoid cavities surrounded by a single layer of cuboidal epithelial cells that appeared to be the ducts of Bowman's glands were sometimes seen within the atrophic epithelium.

Respiratory epithelium hyperplasia was a minimal to moderate change affecting the tall columnar epithelium of the septum in Levels I and II and sometimes the turbinates in Level II as well as the cuboidal to low columnar epithelium on the lateral wall and turbinates in Level I. Hyperplasia was characterized by increased numbers of closely packed epithelial cells with crowded nuclei, which caused thickening of the epithelium and often appeared to form two or three layers rather than the single layer seen normally. Increased numbers of goblet cells were seen within the hyperplastic pseudostratified columnar epithelium and small ovoid cavities surrounded by a single layer of cuboidal epithelial cells that appeared to be the ducts of respiratory glands, were sometimes seen within the hyperplastic cuboidal epithelium on the turbinates and lateral walls. 
Table 6. Incidences of Selected Nonneoplastic Lesions in Rats in the Three-month Inhalation Study of Triethylamine

\begin{tabular}{|c|c|c|c|c|c|c|}
\hline & $\begin{array}{l}\text { Chamber } \\
\text { Control }\end{array}$ & $12.5 \mathrm{ppm}$ & 25 ppm & 50 ppm & 100 ppm & 200 ppm \\
\hline \multicolumn{7}{|l|}{ Male } \\
\hline Nose $^{\mathrm{a}}$ & 10 & 10 & 10 & 10 & 10 & 10 \\
\hline Olfactory Epithelium, Atrophy ${ }^{\mathrm{b}}$ & 0 & 0 & 0 & $10^{* *}(1.6)^{\mathrm{c}}$ & $10 * *(2.2)$ & $10 * *(2.6)$ \\
\hline $\begin{array}{l}\text { Respiratory Epithelium, } \\
\text { Accumulation, Hyaline Droplet }\end{array}$ & 0 & 0 & 0 & 0 & 0 & $3(1.0)$ \\
\hline Respiratory Epithelium, Hyperplasia & 0 & $3(1.0)$ & $9 * *(1.2)$ & $9 * *(1.2)$ & $10 * *(1.7)$ & $10 * *(2.7)$ \\
\hline Lung & 10 & 10 & 10 & 10 & 10 & 10 \\
\hline $\begin{array}{l}\text { Alveolus, Infiltration Cellular, } \\
\text { Histiocyte }\end{array}$ & $4(1.0)$ & $5(1.0)$ & $3(1.0)$ & $2(1.0)$ & $6(1.0)$ & $6(1.0)$ \\
\hline \multicolumn{7}{|l|}{ Female } \\
\hline Nose & 10 & 10 & 10 & 10 & 10 & 10 \\
\hline Olfactory Epithelium, Atrophy & 0 & 0 & $4 *(1.0)$ & $10 * *(1.9)$ & $10 * *(2.5)$ & $10 * *(2.9)$ \\
\hline Respiratory Epithelium, Hyperplasia & 0 & $3(1.0)$ & $9 * *(1.1)$ & $10 * *(1.7)$ & $10 * *(2.4)$ & $10 * *(2.7)$ \\
\hline Lung & 10 & 10 & 10 & 10 & 10 & 10 \\
\hline $\begin{array}{l}\text { Alveolus, Infiltration Cellular, } \\
\text { Histiocyte }\end{array}$ & $2(1.0)$ & $1(1.0)$ & $4(1.0)$ & $4(1.0)$ & $7 *(1.0)$ & $7 *(1.1)$ \\
\hline
\end{tabular}

Hyaline droplet accumulation of the respiratory epithelium was a minimal change in a few $200 \mathrm{ppm}$ males that consisted of an intracytoplasmic accumulation of homogeneously eosinophilic, hyaline material within respiratory epithelial cells along the septum and on the turbinates in Level II (Table 5 and Table A-1).

In the lung, there were significantly increased incidences of histiocyte cellular infiltration of the alveolus in 100 and 200 ppm females (Table 5 and Table A-2). The histiocytic cellular infiltrates were minimal to mild and consisted of one to a few, small, focal, subpleural accumulations of large, clear histiocytes within alveolar spaces, often accompanied by thickening of the alveolar walls due to increased numbers of Type II alveolar epithelial cells and slight fibrous thickening of the adjacent pleura.

One 200 ppm female was observed clinically to have an eye abnormality and four males and six females exposed to 200 ppm exhibited corneal lesions histologically (Table 7, Table A-1, and Table A-2). Mineralization of the subepithelial corneal stroma was noted in three males and two females, and epithelial vacuolation of the microvacuolar type similar to that observed in the 2-week animals was seen in two of the $200 \mathrm{ppm}$ males. Three of the $200 \mathrm{ppm}$ females exhibited subepithelial vesicles, and one female showed focal corneal epithelial ulceration. One male and one female exhibited one or more apoptotic cells within the corneal epithelium (minimal corneal necrosis), and mild chronic inflammation was present within the corneal stroma of this female. One of the 100 ppm males showed minimal mineralization of the corneal stroma. These corneal 
lesions were interpreted as related either to direct chemical effect or to healing changes (such as the mineralization) secondary to chemical injury. Retinal degeneration was also noted in one $50 \mathrm{ppm}$ male, one $25 \mathrm{ppm}$ female, two $100 \mathrm{ppm}$ females, and one $200 \mathrm{ppm}$ female. The etiology of the retinal changes was not certain because retinal degeneration may occur spontaneously in rats, although none was identified in the chamber controls. In addition, the retinal degeneration in the two $100 \mathrm{ppm}$ females was unusual in that the inner portion of the retina (the ganglion cell layer, the inner nuclear layer, and the plexiform layers) was atrophic in contrast to the usual atrophy seen in the outer nuclear and photoreceptor layers; both of these cases were unilateral and patchy. It is possible that retinal damage was caused by triethylamine or a metabolite delivered either directly through the cornea or possibly through the retinal blood supply, although there was limited evidence of systemic toxicity in other organs.

Table 7. Incidences of Nonneoplastic Lesions of the Eye in Rats in the Three-month Inhalation Study of Triethylamine

\begin{tabular}{|c|c|c|c|c|c|c|}
\hline & $\begin{array}{l}\text { Chamber } \\
\text { Control }\end{array}$ & 12.5 ppm & 25 ppm & $50 \mathrm{ppm}$ & 100 ppm & 200 ppm \\
\hline \multicolumn{7}{|l|}{ Male } \\
\hline Number Examined Microscopically & 9 & 10 & 10 & 10 & 10 & 10 \\
\hline Cornea, Mineralization ${ }^{\mathrm{a}}$ & 0 & 0 & 0 & 0 & $1(1.0)^{\mathrm{b}}$ & $3(1.3)$ \\
\hline Cornea, Necrosis & 0 & 0 & 0 & 0 & 0 & $1(1.0)$ \\
\hline Cornea, Epithelium, Vacuolation & 0 & 0 & 0 & 0 & 0 & $2(1.0)$ \\
\hline Retina, Degeneration & 0 & 0 & 0 & $1(2.0)$ & 0 & 0 \\
\hline \multicolumn{7}{|l|}{ Female } \\
\hline Number Examined Microscopically & 10 & 10 & 10 & 10 & 10 & 10 \\
\hline $\begin{array}{l}\text { Anterior Chamber, } \\
\text { Infiltration Cellular, } \\
\text { Macrophage }\end{array}$ & 0 & 0 & 0 & 0 & 0 & $1(1.0)$ \\
\hline Cornea, Edema & 0 & 0 & 0 & 0 & 0 & $1(2.0)$ \\
\hline Cornea, Inflammation, Chronic & 0 & 0 & 0 & 0 & 0 & $1(2.0)$ \\
\hline Cornea, Mineralization & 0 & 2 & 0 & 0 & 0 & $2(1.0)$ \\
\hline Cornea, Necrosis & 0 & 0 & 0 & 0 & 0 & $1(1.0)$ \\
\hline Cornea, Vesicle, Subepithelial & 0 & 0 & 0 & 0 & 0 & 3 \\
\hline Cornea, Epithelium, Ulcer & 0 & 0 & 0 & 0 & 0 & $1(1.0)$ \\
\hline Lens, Cataract & 0 & 0 & 0 & 0 & 0 & $1(1.0)$ \\
\hline Retina, Degeneration & 0 & 0 & $1(1.0)$ & 0 & $2(2.0)$ & $1(2.0)$ \\
\hline Retina, Dysplasia & 0 & 0 & 0 & 0 & 0 & $1(2.0)$ \\
\hline
\end{tabular}

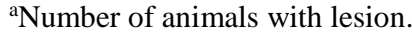

${ }^{\mathrm{b}}$ Average severity grade of lesions in affected animals: $1=$ minimal, $2=$ mild, $3=$ moderate, $4=$ marked. 


\section{Mice}

\section{Two-week Study}

Three males and all females exposed to $1,000 \mathrm{ppm}$ and three females exposed to $800 \mathrm{ppm}$ died after the first exposure on day 1 (Table 8). In the remaining 1,000 ppm males, one animal died on day 3 and one died on day 11 . In the 800 ppm males, one died on day 2, two died on day 3 , and two died on day 11 . The remaining $800 \mathrm{ppm}$ females died on day 8 . Mice exposed to $400 \mathrm{ppm}$ lost weight during the study, and final mean body weights of these mice were significantly less than those of the chamber controls; mean body weight gains of 200 and $400 \mathrm{ppm}$ mice were also significantly less. Lethargy, abnormal breathing, ataxia, tremor, and thinness were observed in all 400 ppm mice; these findings were also observed in the groups that died early. At the end of the study, all $400 \mathrm{ppm}$ male and female rats were observed to be thin and to have abnormal breathing. Clinical signs were not observed in mice exposed to lower concentrations.

Table 8. Survival and Body Weights of Mice in the Two-week Inhalation Study of Triethylamine ${ }^{\text {a }}$

\begin{tabular}{cccccc}
\hline $\begin{array}{c}\text { Concentration } \\
(\mathbf{p p m})\end{array}$ & Survival $^{\mathbf{b}}$ & $\begin{array}{c}\text { Initial Body } \\
\text { Weight } \\
(\mathbf{g})\end{array}$ & $\begin{array}{c}\text { Final Body } \\
\text { Weight } \\
(\mathbf{g})\end{array}$ & $\begin{array}{c}\text { Change in Body } \\
\text { Weight } \\
(\mathbf{g})\end{array}$ & $\begin{array}{c}\text { Final Weight } \\
\text { Relative to } \\
\text { Controls } \\
(\mathbf{\%})\end{array}$ \\
\hline Male & & & & & \\
0 & $5 / 5$ & $22.8 \pm 0.5$ & $26.2 \pm 0.6$ & $3.5 \pm 0.3$ & \\
100 & $5 / 5$ & $22.4 \pm 0.4$ & $25.6 \pm 0.6$ & $3.2 \pm 0.3$ & 97 \\
200 & $5 / 5$ & $22.7 \pm 0.5$ & $24.7 \pm 0.5$ & $2.0 \pm 0.3^{* *}$ & 94 \\
400 & $5 / 5$ & $22.8 \pm 0.4$ & $19.4 \pm 0.6^{* *}$ & $-3.4 \pm 0.4^{* *}$ & 74 \\
800 & $0 / 5^{\mathrm{c}}$ & $22.6 \pm 0.5$ & - & - & - \\
1,000 & $0 / 5^{\mathrm{d}}$ & $22.5 \pm 0.4$ & - & - & - \\
\hline
\end{tabular}

Female

$\begin{array}{cccccc}0 & 5 / 5 & 19.6 \pm 0.3 & 22.7 \pm 0.4 & 3.2 \pm 0.5 & \\ 100 & 5 / 5 & 19.7 \pm 0.5 & 22.9 \pm 0.4 & 3.2 \pm 0.2 & 99 \\ 200 & 5 / 5 & 20.0 \pm 0.5 & 21.8 \pm 0.5 & 1.8 \pm 0.4^{*} & 96 \\ 400 & 5 / 5 & 20.0 \pm 0.3 & 17.1 \pm 0.3^{* *} & -2.9 \pm 0.4^{* *} & 75 \\ 800 & 0 / 5^{\mathrm{e}} & 20.2 \pm 0.5 & - & - & - \\ 1,000 & 0 / 5^{\mathrm{f}} & 19.6 \pm 0.2 & - & - & -\end{array}$

*Significantly different $(\mathrm{P} \leq 0.05)$ from the chamber control group by Williams' test.

$* * \mathrm{P} \leq 0.01$.

${ }^{a}$ Weights and weight changes are given as mean \pm standard error. Subsequent calculations are based on animals surviving to the end of the study.

${ }^{b}$ Number of animals surviving at 17 days/number initially in group.

'Days of death: $2,3,3,11,11$.

${ }^{\mathrm{d}}$ Days of death: $1,1,1,3,11$.

'Days of death: 1, 1, 1, 8, 8 .

fDay of deaths: 1 . 
The absolute liver weights and the absolute and relative thymus weights of 200 and $400 \mathrm{ppm}$ males were significantly less than those of the chamber controls (Table D-3). The absolute and relative liver and thymus weights and the absolute right kidney weight in $400 \mathrm{ppm}$ females were significantly lower than those of the chamber controls. Absolute heart weights in $400 \mathrm{ppm}$ males and females were significantly lower than those of the chamber controls. Absolute organ weight changes were considered to be secondary to body weight changes. Relative organ weight changes in the $400 \mathrm{ppm}$ males and females may also have been associated with the $25 \%$ decrease in mean body weights.

In the nose, turbinate necrosis occurred in all exposed groups of mice except for the $100 \mathrm{ppm}$ groups and the severity increased with increased exposure concentration (Table 9). There were significantly increased incidences of olfactory epithelium atrophy in all surviving groups of exposed mice. There were also significantly increased incidences of acute inflammation and squamous metaplasia of the respiratory epithelium in 200 and $400 \mathrm{ppm}$ males and females, and a few incidences of septum cartilaginous regeneration adjacent to areas of septal necrosis in 400 ppm groups.

Microscopically, minimal to marked turbinate necrosis was characterized by partial to complete destruction of nasoturbinate hooks and maxilloturbinate dorsal tips, often associated with necrosis of the respiratory epithelium and lamina propria adjacent to the necrotic turbinate bone. The nasal septum cartilage was necrotic in Level I of some mice, often in association with zones of hyperplastic chondrocytes (cartilaginous regeneration) adjacent to the central necrotic cartilage. Minimal to marked acute inflammation was usually associated with areas of turbinate necrosis and was seen as collections of neutrophils in or on the nasal mucosa. Some mice had exudates (proteinaceous fluid and neutrophils) in the nasal airways. This inflammation was more prominent in mice that survived beyond day 3 .

Minimal to moderate squamous metaplasia of the respiratory epithelium was seen on the septum, turbinates, and/or lateral walls in Levels I and II of the nose in many mice, as the epithelium regenerated and replaced the more vulnerable respiratory epithelium with one or more layers of low cuboidal or squamous cells. In some mice, soft tissue and bone underlying the squamous metaplasia was still necrotic, especially on turbinate tips. Squamous metaplasia was found in most mice exposed to 200 and $400 \mathrm{ppm}$ as well as $800 \mathrm{ppm}$ mice that lived to at least day 11 .

Olfactory atrophy was mild or moderate in all mice exposed to 100,200 , or $400 \mathrm{ppm}$. Atrophy affected the olfactory epithelium lining the dorsal meatus in Level II, as well as the dorsal septum and adjacent turbinates in Level III. This atrophy was characterized by varying degrees of loss of olfactory sensory neurons from the epithelium, and decreased nerve bundles and Bowman's glands in the lamina propria. The affected epithelium was hypocellular, reduced in height, and often resembled respiratory epithelium, consistent with "respiratory metaplasia."

In the lung, there were incidences of focal necrosis of the mainstem bronchial epithelium in 800 and 1,000 ppm males and females and cytoplasmic vacuolization of the bronchial epithelium in many of the 800 and 1,000 ppm females (Table 9). There were significantly increased incidences of chronic active inflammation of the bronchi in $400 \mathrm{ppm}$ males and females. The bronchial epithelium often exhibited regenerative changes that varied from squamous to columnar with one to multiple layers of cells with increased basophilia. The underlying lamina propria contained mononuclear inflammatory cells, fibroblasts, and occasional clusters of neutrophils. 
Table 9. Incidences of Selected Nonneoplastic Lesions in Mice in the Two-week Inhalation Study of Triethylamine

\begin{tabular}{|c|c|c|c|c|c|c|}
\hline & $\begin{array}{l}\text { Chamber } \\
\text { Control }\end{array}$ & 100 ppm & 200 ppm & 400 ppm & 800 ppm & 1,000 ppm \\
\hline \multicolumn{7}{|l|}{ Male } \\
\hline Nose $^{a}$ & 5 & 5 & 5 & 5 & 5 & 5 \\
\hline Inflammation, Acute ${ }^{\mathrm{b}}$ & 0 & 0 & $5^{* *}(2.0)^{\mathrm{c}}$ & $5 * *(3.0)$ & $3(3.3)$ & 0 \\
\hline Olfactory Epithelium, Atrophy & 0 & $5 * *(2.0)$ & $5 * *(2.0)$ & $5 * *(3.0)$ & 0 & 0 \\
\hline $\begin{array}{l}\text { Respiratory Epithelium, } \\
\text { Metaplasia, Squamous }\end{array}$ & 0 & 0 & $5^{* *}(1.8)$ & $5 * *(3.0)$ & $2(1.5)$ & 0 \\
\hline Turbinate, Necrosis & 0 & 0 & $5 * *(1.8)$ & $5 * *(3.0)$ & $5 * *(4.0)$ & $5 * *(4.0)$ \\
\hline Septum, Regeneration & 0 & 0 & 0 & $3(1.3)$ & 0 & 0 \\
\hline Lung & 5 & 0 & 5 & 5 & 5 & 5 \\
\hline $\begin{array}{l}\text { Bronchus, Inflammation, } \\
\text { Chronic Active }\end{array}$ & 0 & - & 0 & $5 * *(2.2)$ & 0 & 0 \\
\hline Bronchus, Necrosis & 0 & - & 0 & 0 & $3(2.7)$ & $3(3.3)$ \\
\hline \multicolumn{7}{|l|}{ Female } \\
\hline Nose & 5 & 5 & 5 & 5 & 5 & 5 \\
\hline Inflammation, Acute & 0 & $1(1.0)$ & $5 * *(2.0)$ & $5 * *(3.0)$ & $2(3.0)$ & 0 \\
\hline Olfactory Epithelium, Atrophy & 0 & $5 * *(2.0)$ & $5 * *(2.2)$ & $5 * *(2.8)$ & 0 & 0 \\
\hline $\begin{array}{l}\text { Respiratory Epithelium, } \\
\text { Metaplasia, Squamous }\end{array}$ & 0 & 0 & $5^{* *}(1.8)$ & $5^{* *}(3.0)$ & $1(2.0)$ & 0 \\
\hline Turbinate, Necrosis & 0 & 0 & $5 * *(2.0)$ & $5 * *(3.4)$ & $5 * *(3.6)$ & $5 * *(4.0)$ \\
\hline Septum, Regeneration & 0 & 0 & 0 & $3(2.0)$ & 0 & 0 \\
\hline Lung & 5 & 5 & 5 & 5 & 5 & 5 \\
\hline $\begin{array}{l}\text { Bronchus, Inflammation, } \\
\text { Chronic Active }\end{array}$ & 0 & 0 & $1(2.0)$ & $4 *(2.5)$ & 0 & 0 \\
\hline Bronchus, Necrosis & 0 & 0 & 0 & 0 & $3(2.7)$ & $4 *(3.0)$ \\
\hline $\begin{array}{l}\text { Bronchus, Vacuolization } \\
\text { Cytoplasmic }\end{array}$ & 0 & 0 & 0 & 0 & $4 *(2.5)$ & $2(3.0)$ \\
\hline \multicolumn{7}{|c|}{ 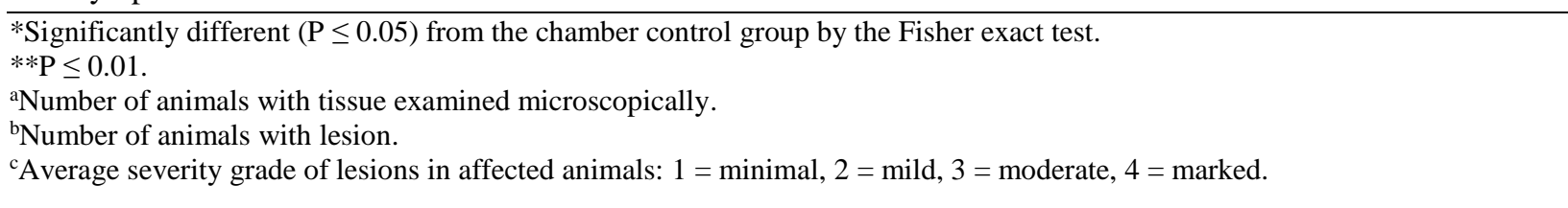 } \\
\hline \multicolumn{7}{|c|}{$\begin{array}{l}\text { In the eye of } 800 \text { and } 1,000 \mathrm{ppm} \text { groups, there were increased incidences of corneal necrosis in } \\
\text { males and significantly increased incidences of this lesion in females (Table 10). In many of } \\
\text { these animals the corneal epithelium was partially absent. Although autolysis was often evident } \\
\text { in the mice dying early, the absence of epithelium was interpreted as ulceration by the PPR } \\
\text { because of the coexisting presence of necrotic debris on the surface, residual clusters of necrotic } \\
\text { cells, and/or the vacuolar degenerative changes in the corneal epithelium of some animals } \\
\text { (Figure 4). Peripheral degeneration of lens fibers (cataracts) was also noted in several } 1,000 \mathrm{ppm} \\
\text { males and females and in } 800 \mathrm{ppm} \text { females. }\end{array}$} \\
\hline
\end{tabular}


Table 10. Incidences of Nonneoplastic Lesions of the Eye in Mice in the Two-week Inhalation Study of Triethylamine

\begin{tabular}{|c|c|c|c|c|c|c|}
\hline & $\begin{array}{c}\text { Chamber } \\
\text { Control }\end{array}$ & 100 ppm & 200 ppm & 400 ppm & 800 ppm & $1,000 \mathrm{ppm}$ \\
\hline \multicolumn{7}{|l|}{ Male } \\
\hline Number Examined Microscopically & 5 & 5 & 5 & 5 & 5 & 5 \\
\hline Cornea, Epithelium, Ulcer ${ }^{\mathrm{a}}$ & 0 & 0 & 0 & 0 & $2(3.5)^{\mathrm{b}}$ & $3(3.3)$ \\
\hline Cornea, Epithelium, Vacuolation & 0 & 0 & 0 & 0 & $3(1.3)$ & $3(1.3)$ \\
\hline Cornea, Necrosis & 0 & 0 & 0 & 0 & $2(2.0)$ & $3(2.7)$ \\
\hline Lens, Cataract & 0 & 0 & 0 & 0 & 0 & $3(1.7)$ \\
\hline \multicolumn{7}{|l|}{ Female } \\
\hline Number Examined Microscopically & 5 & 5 & 5 & 5 & 4 & 4 \\
\hline Cornea, Epithelium, Ulcer & 0 & 0 & 0 & $1(1.0)$ & $3 *(4.0)$ & $4 * *(3.5)$ \\
\hline Cornea, Epithelium, Vacuolation & 0 & 0 & 0 & 0 & 0 & $1(2.0)$ \\
\hline Cornea, Necrosis & 0 & 0 & 0 & 0 & $3 *(2.3)$ & $4 * *(2.8)$ \\
\hline Lens, Cataract & 0 & 0 & 0 & 0 & $3 *(2.0)$ & $4 * *(2.0)$ \\
\hline \multicolumn{7}{|c|}{$\begin{array}{l}\text { *Significantly different }(\mathrm{P} \leq 0.05) \text { from the chamber control group by the Fisher exact test. } \\
* * \mathrm{P} \leq 0.01 \text {. } \\
\text { aNumber of animals with lesion. } \\
\text { bAverage severity grade of lesions in affected animals: } 1=\text { minimal, } 2=\text { mild, } 3=\text { moderate, } 4=\text { marked. }\end{array}$} \\
\hline \multicolumn{7}{|c|}{$\begin{array}{l}\text { Exposure concentration selection rationale. Exposure to concentrations of } 800 \text { and } 1,000 \mathrm{ppm} \\
\text { resulted in decreased survival. Exposure to } 400 \mathrm{ppm} \text { resulted in decreased body weights } \\
\text { (approximately } 25 \% \text { ), decreased organ weights, and moderate histopathologic changes in the } \\
\text { nose of male and female mice. The effects on body weight and the nasal cavity were less severe } \\
\text { in groups exposed to } 200 \mathrm{ppm} \text { or less. Therefore, exposure concentrations of } 0,12.5,25,50,100 \text {, } \\
\text { and } 200 \mathrm{ppm} \text { triethylamine were selected for the } 3 \text {-month study. }\end{array}$} \\
\hline
\end{tabular}

All mice survived to the end of the study (Table 11). The final mean body weights and body weight gains of males and females exposed to $200 \mathrm{ppm}$ were significantly less than those of the chamber controls (Table 11; Figure 3). No clinical findings related to triethylamine exposure were observed. 
Table 11. Survival and Body Weights of Mice in the Three-month Inhalation Study of Triethylamine $^{a}$

\begin{tabular}{|c|c|c|c|c|c|}
\hline Concentration (ppm) & Survival $^{\text {b }}$ & $\begin{array}{c}\text { Initial Body } \\
\text { Weight } \\
\text { (g) }\end{array}$ & $\begin{array}{l}\text { Final Body } \\
\text { Weight } \\
\text { (g) }\end{array}$ & $\begin{array}{l}\text { Change in } \\
\text { Body Weight } \\
\text { (g) }\end{array}$ & $\begin{array}{c}\text { Final Weight } \\
\text { Relative to } \\
\text { Controls } \\
(\%)\end{array}$ \\
\hline \multicolumn{6}{|l|}{ Male } \\
\hline 0 & $10 / 10$ & $22.9 \pm 0.2$ & $37.6 \pm 0.8$ & $14.7 \pm 0.6$ & \\
\hline 12.5 & $10 / 10$ & $22.8 \pm 0.3$ & $38.3 \pm 0.9$ & $15.6 \pm 0.7$ & 102 \\
\hline 25 & $10 / 10$ & $22.3 \pm 0.2$ & $37.6 \pm 0.7$ & $15.2 \pm 0.6$ & 100 \\
\hline 50 & $10 / 10$ & $22.9 \pm 0.3$ & $38.6 \pm 0.5$ & $15.7 \pm 0.5$ & 103 \\
\hline 100 & $10 / 10$ & $23.0 \pm 0.3$ & $38.3 \pm 0.6$ & $15.3 \pm 0.4$ & 102 \\
\hline 200 & $10 / 10$ & $22.9 \pm 0.3$ & $31.9 \pm 0.6^{* *}$ & $9.1 \pm 0.6^{* *}$ & 85 \\
\hline \multicolumn{6}{|l|}{ Female } \\
\hline 0 & $10 / 10$ & $19.7 \pm 0.3$ & $32.8 \pm 0.8$ & $13.1 \pm 0.8$ & \\
\hline 12.5 & $10 / 10$ & $19.8 \pm 0.3$ & $32.8 \pm 0.9$ & $13.1 \pm 0.7$ & 100 \\
\hline 25 & $10 / 10$ & $19.1 \pm 0.3$ & $31.4 \pm 0.8$ & $12.3 \pm 0.8$ & 96 \\
\hline 50 & $10 / 10$ & $20.1 \pm 0.3$ & $33.7 \pm 0.5$ & $13.7 \pm 0.5$ & 103 \\
\hline 100 & $10 / 10$ & $19.4 \pm 0.3$ & $33.0 \pm 0.4$ & $13.6 \pm 0.4$ & 101 \\
\hline 200 & $10 / 10$ & $19.4 \pm 0.3$ & $29.3 \pm 0.5^{* *}$ & $9.9 \pm 0.5^{* *}$ & 89 \\
\hline
\end{tabular}

**Significantly different $(\mathrm{P} \leq 0.01)$ from the chamber control group by Dunnett's test.

${ }^{a}$ Weights and weight changes are given as mean \pm standard error.

${ }^{b}$ Number of animals surviving at 14 weeks/number initially in group. 
Triethylamine, NTP TOX 78
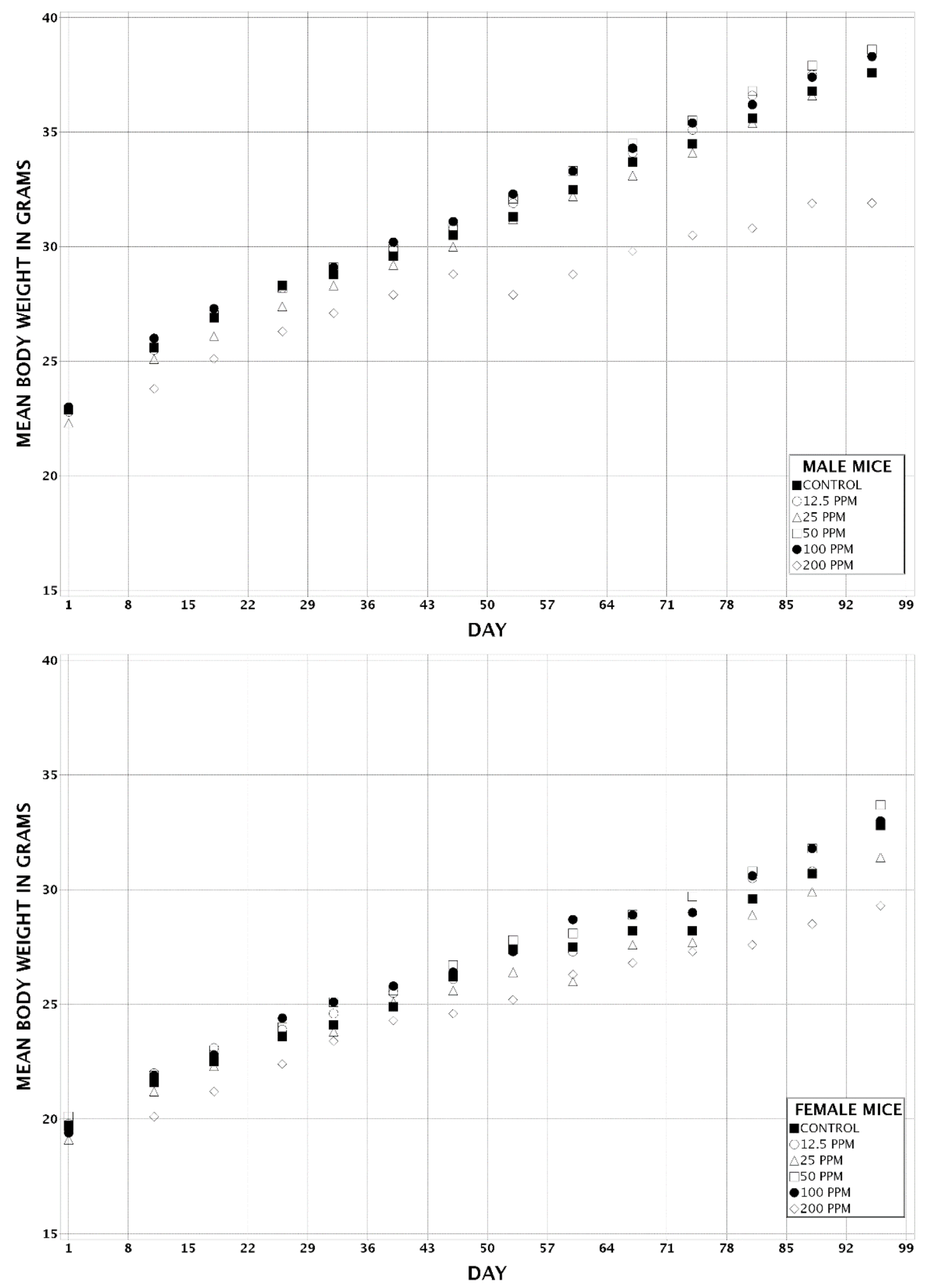

Figure 3. Growth Curves for Mice Exposed to Triethylamine by Inhalation for Three Months

There were no changes in the hematology endpoints that were attributable to inhalation of triethylamine (Table C-2). 
The absolute and relative heart weights of $100 \mathrm{ppm}$ females were significantly greater than those of the chamber controls (Table D-4). The lower absolute heart, right kidney, liver, and thymus weights of $200 \mathrm{ppm}$ males and absolute liver weight of $200 \mathrm{ppm}$ females were considered to be related to lower body weights.

No histopathologic changes were noted in the testes of male mice at 3 months. The weight of the left epididymis and testis in the $200 \mathrm{ppm}$ group was significantly lower than that of the chamber control group (Table E-4). In females, there was an overall nonstatistically significant difference between the $200 \mathrm{ppm}$ group and the chamber controls in the time spent in various stages of estrous (Table E-5 and Table E-6; Figure E-2).

In the nose, necrosis of the lateral hooks of the nasoturbinates was present in all 200 ppm males and females and was sometimes associated with ulceration of the overlying respiratory epithelium (Table 12, Table A-3, and Table A-4). Necrosis of bone was characterized by empty osteocyte lacunae, absence of lining cells (osteoblasts), attenuation and scalloping of the bone, fragmentation, and sometimes extrusion of the bone into the nasal cavity (Figure 5). Aggregates of neutrophils and bits of debris that may have been necrotic bone were seen at the ulcerated site, and hyperplasia of the epithelium bordering on the ulcer was sometimes present. Atrophy of the nastoturbinates was also noted in five males and three females exposed to $200 \mathrm{ppm}$.

In the olfactory epithelium, there were significantly increased incidences of olfactory epithelial atrophy in males and females exposed to $50 \mathrm{ppm}$ or greater, hyaline droplet accumulation in females exposed to $50 \mathrm{ppm}$ or greater and $100 \mathrm{ppm}$ males, and cytoplasmic vacuolization in $50 \mathrm{ppm}$ males and females (Table 12, Table A-3, and Table A-4). In the respiratory epithelium of the nose, there were significantly increased incidences of hyaline droplet accumulation in $100 \mathrm{ppm}$ males and in females exposed to $50 \mathrm{ppm}$ or greater, and significantly increased incidences of squamous metaplasia in $200 \mathrm{ppm}$ males and females. In all exposed groups of males and females, the incidences of turbinate hyperostosis were significantly increased and were particularly prominent in the nasoturbinates. The severities of olfactory epithelium atrophy and turbinate hyperostosis in males and females increased with increasing exposure concentration.

Microscopically, olfactory epithelium atrophy consisted of a minimal to moderate loss of olfactory sensory neurons from the epithelium, accompanied by decreased nerve bundles and Bowman's glands in the lamina propria. The affected epithelium was hypocellular and reduced in height, and sometimes was replaced by a ciliated, columnar respiratory-like epithelium. Minimal to mild lesions consisted of an increasing loss of sensory cells, nerve bundles, and Bowman's glands in Level II. Moderate lesions involved the dorsal meatus of Level II, as well as the dorsal meatus, septum, and ethmoid turbinates in Level III. The atrophic epithelium in the dorsal meatus of Level II was sometimes replaced by a columnar respiratory-like epithelium. 
Triethylamine, NTP TOX 78

Table 12. Incidences of Nonneoplastic Lesions of the Nose in Mice in the Three-month Inhalation Study of Triethylamine

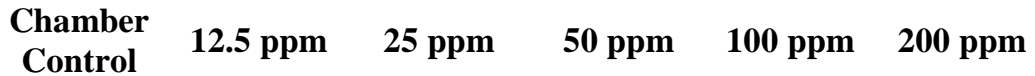

\begin{tabular}{|c|c|c|c|c|c|c|}
\hline \multicolumn{7}{|l|}{ Male } \\
\hline Number examined microscopically & 10 & 10 & 10 & 10 & 10 & 10 \\
\hline Olfactory epithelium, atrophy ${ }^{\mathrm{a}}$ & 0 & 0 & 0 & $9 * *(1.4)^{\mathrm{b}}$ & $10 * *(3.0)$ & $10 * *(3.0)$ \\
\hline $\begin{array}{l}\text { Olfactory epithelium, accumulation, } \\
\text { hyaline droplet }\end{array}$ & 0 & 0 & 0 & $1(1.0)$ & $6 * *(1.2)$ & 0 \\
\hline $\begin{array}{l}\text { Olfactory epithelium, } \\
\text { vacuolization cytoplasmic }\end{array}$ & 0 & 0 & 0 & $6^{* *}(1.8)$ & 0 & 0 \\
\hline $\begin{array}{l}\text { Respiratory epithelium, } \\
\text { accumulation, hyaline droplet }\end{array}$ & 0 & 0 & 0 & 0 & $9 * *(1.7)$ & 0 \\
\hline $\begin{array}{l}\text { Respiratory epithelium, } \\
\text { metaplasia, squamous }\end{array}$ & 0 & 0 & 0 & 0 & 0 & $10 * *(1.1)$ \\
\hline Turbinate, hyperostosis & 0 & $10 * *(1.0)$ & $9 * *(2.1)$ & $10 * *(2.6)$ & $10 * *(3.5)$ & $10 * *(3.8)$ \\
\hline Turbinate, necrosis & 0 & 0 & 0 & 0 & 0 & $10 * *(2.6)$ \\
\hline Turbinate, atrophy & 0 & 0 & 0 & 0 & 0 & $5 *(2.0)$ \\
\hline \multicolumn{7}{|l|}{ Female } \\
\hline Number examined microscopically & 10 & 10 & 10 & 10 & 10 & 10 \\
\hline Olfactory epithelium, atrophy & 0 & 0 & 0 & $10 * *(1.7)$ & $10 * *(2.8)$ & $10 * *(3.0)$ \\
\hline $\begin{array}{l}\text { Olfactory epithelium, } \\
\text { accumulation, hyaline droplet }\end{array}$ & 0 & 0 & 0 & $7 * *(1.3)$ & $10 * *(2.7)$ & $8^{* *}(1.9)$ \\
\hline $\begin{array}{l}\text { Olfactory epithelium, } \\
\text { vacuolization cytoplasmic }\end{array}$ & 0 & 0 & 0 & $5^{*}(2.0)$ & 0 & 0 \\
\hline $\begin{array}{l}\text { Respiratory epithelium, } \\
\text { accumulation, hyaline droplet }\end{array}$ & 0 & 0 & 0 & $7 * *(1.9)$ & $10 * *(3.2)$ & $8^{* *}(2.4)$ \\
\hline $\begin{array}{l}\text { Respiratory epithelium, } \\
\text { metaplasia, squamous }\end{array}$ & 0 & 0 & 0 & 0 & 0 & $9 * *(1.4)$ \\
\hline Turbinate, hyperostosis & 0 & $8 * *(1.0)$ & $10 * *(1.6)$ & $10 * *(2.7)$ & $9 * *(3.2)$ & $10 * *(4.0)$ \\
\hline Turbinate, necrosis & 0 & 0 & 0 & 0 & 0 & $10 * *(2.8)$ \\
\hline Turbinate, atrophy & 0 & 0 & 0 & 0 & 0 & $3(3.0)$ \\
\hline
\end{tabular}

*Significantly different $(\mathrm{P} \leq 0.05)$ from the chamber control group by the Fisher exact test.

$* * \mathrm{P} \leq 0.01$

${ }^{\mathrm{a}}$ Number of animals with lesion.

${ }^{\mathrm{b}}$ Average severity grade of lesions in affected animals: $1=$ minimal, $2=$ mild, $3=$ moderate, $4=$ marked.

Hyaline droplet accumulation in the olfactory epithelium consisted of an intracytoplasmic accumulation of homogeneously eosinophilic, hyaline material. It was minimal to mild in males and minimal to moderate in females. Similar changes affected the respiratory epithelium of both males and females. They were minimal to moderate in males and minimal to marked in females.

Cytoplasmic vacuolization of the olfactory epithelium was minimal to mild in males and minimal to moderate in females and consisted of multiple small to moderately large, round to 
ovoid, clear spaces scattered diffusely within the atrophic olfactory epithelium of the dorsal meatus in Level II.

Minimal to mild squamous metaplasia of the respiratory epithelium affected the cuboidal epithelium of the turbinates and lateral wall in Level I and was characterized by replacement of the normal cuboidal epithelium with one to three layers of flattened, squamous epithelial cells. The adjacent cuboidal epithelium in some of these animals was slightly thickened and hypercellular.

Hyperostosis of the nasal turbinates (Figure 5) was characterized by varying degrees of thickening of the nasal bones, particularly the naso- and maxilloturbinate bones, the nasal septum, and the skull overlying the nasal cavity. Normally the turbinate bones and skull consist of poorly cellular, layered, well-organized lamella bone. The affected bones were thickened by the deposition of cellular, disorganized woven bone, indicative of active bone formation or by bone with mixed woven and lamellar features. The thickened turbinates were characterized by numerous cement lines, which were often irregular and indicative of reversal cement lines, and the presence of numerous empty osteocyte lacunae. Lining cells (osteoblasts) were usually seen on the outer surface of the turbinates, but osteoclasts were seldom seen except occasionally in association with resorption of necrotic naso- or maxilloturbinate hooks. The severity of this change ranged from minimal to marked, with the average severity increasing with increasing dose. Minimal lesions consisted of slight thickening of the nasoturbinates and sometimes of the skull in Level I. Mild lesions consisted of fairly prominent thickening of the nasoturbinates usually with slight thickening of the tips of the maxilloturbinates and the skull in Level I. Moderate lesions consisted of prominent thickening of the naso- and maxilloturbinates and the skull in Level I. Marked lesions consisted of pronounced thickening of the naso- and maxilloturbinates and the skull in Level I, usually with obvious involvement of the bones in Level II as well.

\section{Genetic Toxicology}

Triethylamine (100 to 10,000 $\mu \mathrm{g}$ /plate) was not mutagenic in Salmonella typhimurium strains TA98, TA100, TA1535, or TA1537 with or without hamster liver S9 activation enzymes(Table B-1; Zeiger et al. ${ }^{39}$ )

A small, concentration-related increase in the frequency of micronucleated erythrocytes (biomarkers of chromosomal damage) was observed in peripheral blood of male mice in the 3month study; the response, which was judged to be equivocal, was observed over the exposure concentration range of 12.5 to $200 \mathrm{ppm}$ (Table B-2). No single exposed group was significantly elevated over the concurrent chamber control, but the trend test yielded a significant $\mathrm{P}$ value (0.006). No increase in micronucleated erythrocytes was seen in female mice. No significant changes in the percentage of polychromatic erythrocytes (immature erythrocytes) were noted in either male or female mice exposed to triethylamine, indicating an absence of bone marrow toxicity. 

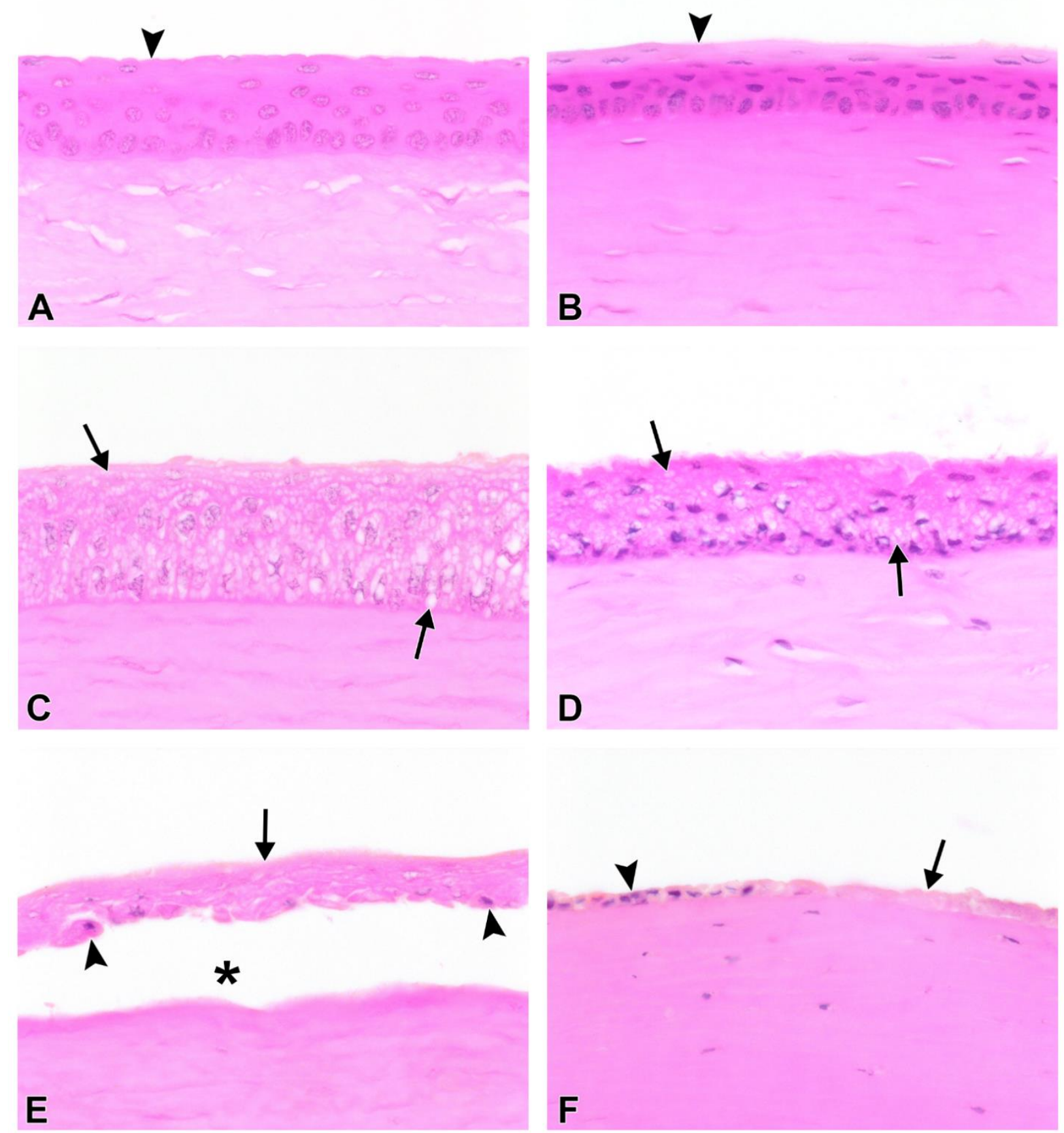

Figure 4. Corneal Epithelial Vacuolation and Necrosis in F344/N Rats and B6C3F1/N Mice Exposed to Triethylamine by Inhalation for up to Two Weeks (H\&E)

A) Normal corneal epithelium (arrowhead) in a chamber control male rat. B) Normal corneal epithelium (arrowhead) in a chamber control female mouse. C) Microvacuolation of the corneal epithelium (arrows) in a female rat exposed to 1,000 ppm triethylamine for 1 day. D) Microvacuolation of the corneal epithelium (arrows) in a male mouse exposed to 1,000 ppm triethylamine for 11 days. E) Necrosis of the corneal epithelium in a male rat exposed to 1,000 ppm triethylamine for 1 day with karyolysis (arrow), scattered nuclear pyknosis (arrowheads), and detachment of the epithelium from the stroma (asterisk in the gap). F) Necrosis of the corneal epithelium in a female mouse exposed to $1,000 \mathrm{ppm}$ triethylamine for 1 day with nuclear pyknosis (arrowhead) and karyolysis (arrow). Original objective magnification: $40 \times$ for all photos. 

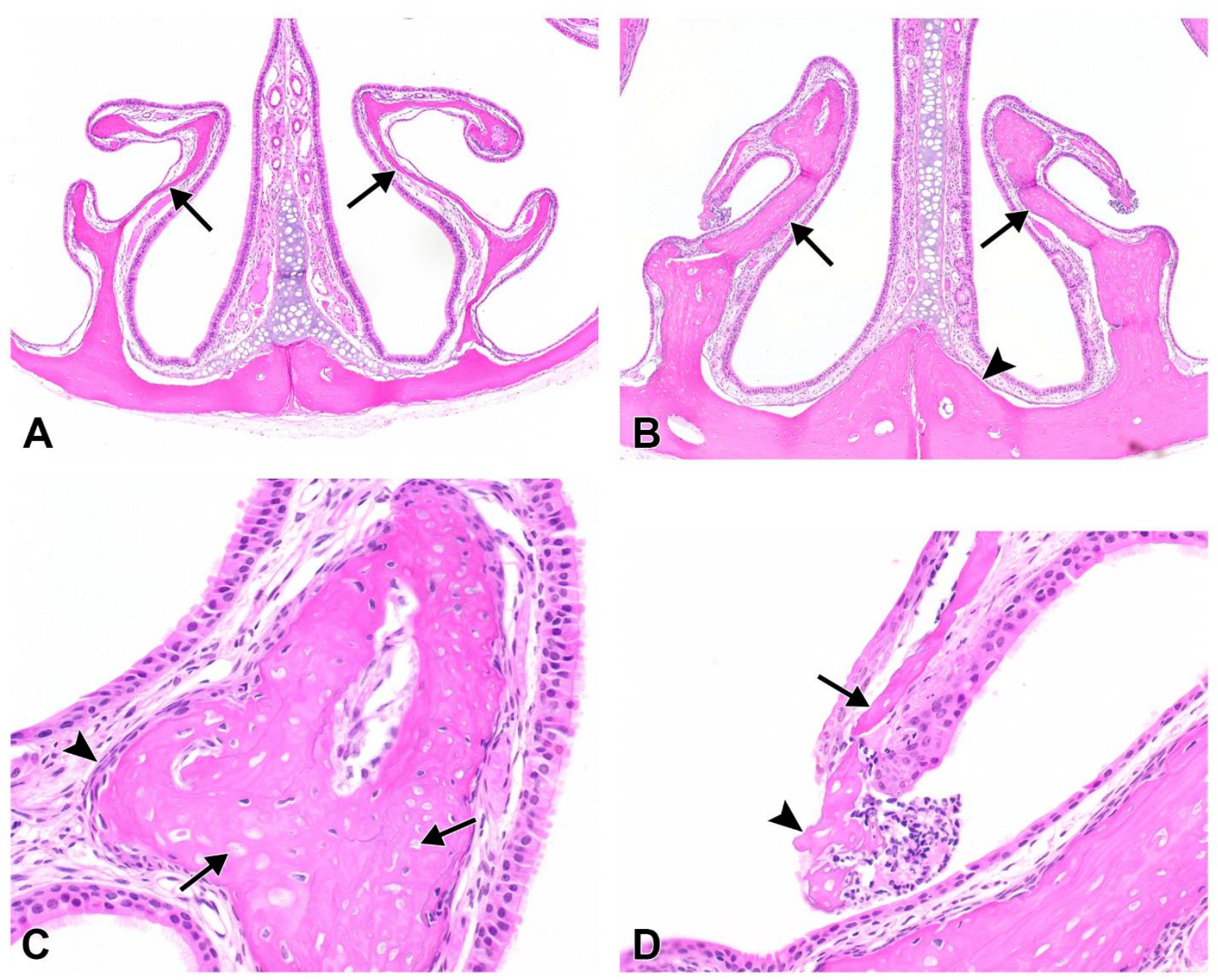

Figure 5. Nasal Turbinate Hyperostosis and Necrosis in B6C3F1/N Mice Exposed to Triethylamine by Inhalation for Three Months (H\&E)

A) Normal slender nasoturbinate bones (arrows) in a chamber control female mouse. B) Thickened (hyperostotic) nasoturbinates (arrows) in a female mouse exposed to $200 \mathrm{ppm}$ triethylamine. Note that the nasal crest is also thickened (arrowhead) in this image taken at the same magnification as image A. C) Hyperostosis of the nasoturbinate in a female mouse exposed to $200 \mathrm{ppm}$ triethylamine. Although there are many empty osteocyte lacunae (arrows) indicative of osteocyte necrosis, the osteoblasts rimming the bone (arrowhead) are viable and activated, and the bone is markedly thickened. D) Necrosis of the lateral hook of the nasoturbinate (arrow) in a female mouse exposed to $200 \mathrm{ppm}$ triethylamine. The necrosis is characterized by the absence of both osteocytes and osteoblasts, attenuation of the bone, and extrusion of the distal end of the hook (arrowhead) into the nasal cavity accompanied by neutrophilic exudate. Original objective magnification: $A=4 \times, B=4 \times, C=20 \times, D=20 \times$. 


\section{Discussion}

Triethylamine is a highly alkaline and corrosive aliphatic amine with widespread occupational use. Because it has a relatively high vapor pressure, inhalation exposure to triethylamine vapors is an occupational hazard in industries where it is used. Triethylamine is a direct-acting contact irritant, and exposure to its vapors can cause irritation to the eyes and the mucous membranes lining the respiratory tract. Exposure of workers to triethylamine vapors results primarily in irritation of the eyes at concentrations greater than $5 \mathrm{ppm}$ and irritation of the nose and throat at higher concentrations (greater than $15 \mathrm{ppm}$ ) resulting in coughing and wheezing ${ }^{8}$. Although respiratory distress can occur in situations of extreme exposure ${ }^{36}$, acute occupational exposures to triethylamine are usually self-limiting because the severe irritation to the eyes, nose, and throat results in workers being removed from exposure.

The target sites for triethylamine vapors are similar in humans and rodents; however, because rodents are obligate nose breathers the nasal cavity is often more severely affected than in humans. The nasal cavity is the primary target site for rodents exposed to many direct-acting, reactive, gaseous chemicals such as chlorine ${ }^{58}$, formaldehyde, ammonia ${ }^{59}$, acetaldehyde ${ }^{60}$, and acrolein $^{61}$. In addition to the nasal irritation, aliphatic amines also have been reported to cause tracheitis, bronchitis, pneumonitis and pulmonary edema ${ }^{62-65}$.

In the current studies, triethylamine toxicity was primarily restricted to the nose and eye. Species and gender differences in susceptibility to triethylamine were minor. In 2-week studies, triethylamine was lethal for rats and mice exposed to concentrations of 800 or $1,000 \mathrm{ppm}$. Marked necrosis of the olfactory epithelium of the nose in rats and bronchial necrosis and corneal degeneration (vacuolation) and necrosis in both rats and mice were present in animals that died early. These lesions in the nose and bronchi were not observed in surviving rats exposed to $400 \mathrm{ppm}$ or less, although corneal lesions of lesser severity were noted in a few 400 ppm females and a few 200 and 100 ppm male and female rats. Nasal lesions were exposure concentration-related in surviving animals and were most severe in rats and mice exposed to $400 \mathrm{ppm}$. The observed decreases in body weights may have been related to a reduced feed intake associated with triethylamine effects on olfaction.

Exposure to 400 ppm triethylamine for 2 weeks caused necrosis of turbinate bone, squamous metaplasia of respiratory epithelium, and atrophy of olfactory epithelium. At $400 \mathrm{ppm}$, lesions also extended to the lower airways with bronchial degeneration and suppurative inflammation in rats and chronic active inflammation of the bronchi in mice. Exposure to $200 \mathrm{ppm}$ produced less severe bronchial and nasal lesions than produced by $400 \mathrm{ppm}$, and at $100 \mathrm{ppm}$ there were no lung lesions and nasal lesions were minimal except for mild olfactory epithelial atrophy in mice. Similar types of nasal lesions (turbinate necrosis, squamous metaplasia, and olfactory atrophy) in rats and mice were observed after exposure for 2 weeks to the structurally related aliphatic amine, diethylamine ${ }^{66}$.

In the 3-month studies, nasal lesions in rats consisted primarily of respiratory epithelial hyperplasia and olfactory epithelial atrophy, and the severity of nasal lesions increased with increasing exposure concentration. On the other hand, nasoturbinate necrosis was present in all male and female mice exposed to $200 \mathrm{ppm}$ triethylamine and turbinate atrophy was present in several of these $200 \mathrm{ppm}$ mice. In addition, hyperostosis (osteopetrosis) of the turbinates was 
present in almost all mice exposed for 3 months, and the severity increased with increasing triethylamine concentration. Hyperostosis of the nasal turbinates is an uncommon nonneoplastic thickening of the naso- and maxilloturbinate bones. Mechanisms of hyperostosis may be divided into proliferative and nonproliferative categories, based upon evidence of either increased bone cell proliferation or decreased bone resorption, respectively ${ }^{67}$. This lesion has been reported in 15 (including the current study) of over 500 NTP studies. Most of these 15 studies were 2-year studies, and the incidences of hyperostosis were low and not dose related. In only four of these 15 studies did there appear to be a significant association with treatment; three of these were inhalation studies (triethylamine, diethylamine, and 1,2-epoxybutane), and one was a chronic feed study (C.I. Pigment Red 3) ${ }^{6 ;}$; 68; 69. The triethylamine (3-month) and diethylamine (2-year) studies were unique in that all of the mice exposed to the highest concentrations exhibited the lesion, whereas only low incidences were reported in the other studies. In addition, hyperostosis of the turbinates was observed in only a few rats in the 2-year diethylamine study and none in the 3 -month triethylamine study, suggesting a species difference in susceptibility.

Corneal irritation and edema have been documented in workers exposed to triethylamine concentrations as low as 4 to $6 \mathrm{ppm}^{33}$. In the current 2-week rat study, the no-observed-effect level (NOEL) for ocular lesions was less than $100 \mathrm{ppm}$. These lesions consisted of corneal degeneration (vacuolation), corneal necrosis, and cataracts in both rats and mice exposed to the higher exposure concentrations. With the reduced exposure concentrations used in the 3-month studies, ocular lesions were less severe in the rats and absent in the mice. Because triethylamine reacts directly with the corneal epithelium, it is unlikely that rodents are more resistant than humans to these ocular effects, but rather the animals were able to limit ocular exposure by closing their eyes during the 6-hour exposures. These exposures also took place during daytime when rodents are not normally awake and active. The visual disturbances reported by workers are the earliest and most sensitive markers of triethylamine exposure. Visual disturbances included irritation, blurred vision, glaucopsia (blue-gray vision), and halo vision. Although these changes may also occur in rodents, detection of these markers is not clinically possible.

The mechanism(s) by which triethylamine and other amines cause visual disturbances is unknown. It has been suggested that edema and increased corneal thickness may cause light scattering resulting in the reported visual effects ${ }^{32 ; 70}$. Mellerio and Weale ${ }^{32}$ also proposed that glaucopsia may be related to the Tyndall effect caused by denaturation of proteins in the corneal epithelium. Corneal edema and mydriasis with cycloplegia have also been proposed as major reasons for the visual disturbances caused by amines ${ }^{71}$. Halo vision reported by exposed workers may result from diffraction of light into spectral colors by droplets of fluid in the corneal epithelia ${ }^{70}$. Examination of corneas of workers exposed to aliphatic amines under slit-lamp microscopy revealed a diffuse edema with numerous small vesicular collections of fluid within the corneal stroma ${ }^{72}$. As noted in the Results section of the current Toxicity Study Report, microvacuolation of the corneal epithelium was seen in many of the rats and mice in the high exposure concentration groups in the 2-week studies. The subepithelial vesicles of the cornea that were present in some of the exposed male and female rats in the current study are probably similar to the subepithelial microcysts reported by Järvinen et al. ${ }^{73}$ and the subepithelial vesicles described by Potts et al. ${ }^{74}$ and Dernehl ${ }^{72}$ in humans exposed to triethylamine.

Inhaled triethylamine is readily absorbed from the lungs and can be detected in urine and plasma in humans ${ }^{18 ;} 19$ suggesting that pulmonary absorption and systemic exposure to triethylamine can also occur in exposed rats and mice. While systemic exposure may have occurred in the current 
study, there was little evidence of systemic toxicity. Some organ weights of rats and mice were significantly different from those of the chamber controls, suggesting potential systemic toxicity. The lower absolute organ weights and higher relative organ weights were attributed to significantly lower body weights.

The high urinary excretion of triethylamine in exposed humans ${ }^{17}$ and the significantly higher relative kidney weights of male and female rats in the 2-week and 3-month studies suggested potential systemic exposure-related nephrotoxicity. Similarly, relative kidney weights in male and female rats exposed for 3 months to the structurally related aliphatic amine, diethylamine, were greater than those of the chamber controls ${ }^{66}$. However, in both the current study and the diethylamine study, higher relative kidney weights were not associated with histopathologic lesions or chemical-related effects on clinical pathology indices. Although mild kidney toxicity due to systemic exposure cannot be ruled out, the lack of histopathologic evidence and lower absolute kidney weights suggest that these effects were related to the significantly lower body weights. Importantly, exposure of rats and mice to diethylamine for 2 years did not result in kidney toxicity ${ }^{66}$.

Retinal degeneration was observed in a few exposed rats in the 3-month study of triethylamine. Unlike the cornea, the retina is not directly exposed to triethylamine vapor, suggesting potential exposure via the blood. However, it is more likely that retinal effects were caused by triethylamine absorbed from the ocular surface. Alkaline chemicals such as triethylamine are known to readily penetrate into the eye. The absorbed alkali can damage the cornea as well as other anterior segment structures ${ }^{75}$ and cause a rapid rise in intraocular pressure and in the anterior chamber $\mathrm{pH}^{76 ; 77}$, all of which could contribute to the retinal degeneration. It is also possible that the low incidences of retinal degeneration were not exposure related. Although retinal changes were not present in chamber control rats, the incidences in exposed groups were not concentration related or statistically significant. Chronic exposure of rats and mice to the related compound, diethylamine, did not result in exposure-related retinal changes.

Also suggestive of a potential systemic effect was the decreased sperm motility in rats exposed to 50,100 , or $200 \mathrm{ppm}$ triethylamine for 3 months. Although these changes were small in magnitude (3\% to $6 \%$ lower than chamber control values), they were exposure concentration related and statistically significant. These rats also displayed lower total number of sperm/cauda ( $4 \%$ to $9 \%$ ) and concomitant significant increases in the number of spermatid/mg testis at the 100 and $200 \mathrm{ppm}$ exposure concentrations. Taken together, these data are suggestive of a potential effect on sperm transit from the testis to the epididymis; however, this apparent effect was small in magnitude. Male mice exposed to $200 \mathrm{ppm}$ triethylamine for 3 months exhibited lower epididymis and testis weights (10\% and 5\%, respectively) compared to the chamber controls. A concentration-related decrease in sperm motility was also reported for male rats and mice exposed for 3 months to the related chemical, diethylamine ${ }^{66}$. There was no histopathologic evidence of testicular toxicity in rats or mice exposed to either triethylamine or diethylamine for 3 months, or in rats or mice exposed to diethylamine for 2 years. However, the effects noted above on the sperm parameters and the reproductive organ weights suggest that triethylamine exhibits the potential to be a reproductive toxicant in male $\mathrm{F} 344 / \mathrm{N}$ rats and $\mathrm{B} 6 \mathrm{C} 3 \mathrm{~F} 1 / \mathrm{N}$ mice.

Chronic studies of triethylamine were not conducted because subchronic toxicity was similar to that of diethylamine, a closely related aliphatic amine that was previously selected for evaluation of carcinogenicity. 
Under the conditions of the 3-month inhalation studies, there were treatment-related lesions in male and female rats and mice. The major targets of triethylamine exposure in rats and mice included the nose and eyes. In rats, the most sensitive measure of triethylamine exposure was respiratory epithelium hyperplasia of the nasal cavity with a lowest-observed-effect level (LOEL) of $12.5 \mathrm{ppm}$ in males and females. In mice, the most sensitive measure of triethylamine exposure was turbinate hyperostosis of the nasal cavity with a LOEL of $12.5 \mathrm{ppm}$ in males and females. 


\section{References}

1. American Conference of Governmental Industrial Hygienists (ACGIH). Documentation of the threshold limit values and biological exposure indices. Cincinnati, OH; 1986.

2. Lewis R. Sax's dangerous properties of industrial materials. New York, NY: Van Nostrand Reinhold; 1992.

3. Nelson MA, Bull RJ. Triethylamine In: Buhler DR, Reed DJ, editors. Ethel Browning's Toxicity and Metabolism of Industrial Solvents: Nitrogen and Phosphorus Solvents. 2nd ed. Netherlands: Elsevier Science; 1990. p. 129-133. http://dx.doi.org/10.1016/B978-0-444-813169.50027-X

4. Schweizer AE, Fowlkes RL, McMakin JH, Whyte TE, Jr. Aliphatic amines In: Standen A, editor. Kirk-Othmer Encyclopedia of Chemical Technology. 2nd ed. New York, NY: John Wiley \& Sons; 1978. p. 272-283.

5. United States Environmental Protection Agency (USEPA). High Production Volume (HPV) challenge program. United States Environmental Protection Agency; 2007.

http://www.epa.gov/hpv

6. SRI International (SRI). Alkylamines. United States, consumption, ethylamines, triethylamine. In: Chemical Economics Handbook. Menlo Park, CA: SRI International; 1997. DIALOG File 359.

7. MacBain G, Strange RC. Foundries. In: Encyclopedia of Occupational Health and Safety. 3rd ed. Geneva, Switzerland: International Labour Office; 1983. p. 916-923.

8. Warren DW, Selchan DF. An industrial hygiene appraisal of triethylamine and dimethylethylamine exposure limits in the foundry industry. Am Ind Hyg Assoc J. 1988;

49(12):630-634. http://dx.doi.org/10.1080/15298668891380367

9. Conrard R. Cold-box coremaking-ashland process. Les Cahiers De Notes Documentaires:

Sécurité Et Hygiène Du Travail. 1977; 87:195-203.

10. Kay R. Survey into the fumes evolved from foundry sand binders based on synthetic resins. Br Foundryman. 1974; 67:1-4.

11. Hansen MK, Larsen M, Cohr K-H. Waterborne paints: A review of their chemistry and toxicology and the results of determinations made during their use. Scand J Work Environ Health. 1987; 13(6):473-485. http://dx.doi.org/10.5271/sjweh.2010

12. Sax N. Chemical review of triethylamine. In: Sax's Dangerous Properties of Industrial Materials. 10th ed. New York, NY: Van Nostrand Reinhold; 1994. p. 2-27.

13. National Institute for Occupational Safety and Health (NIOSH). National Occupational Exposure Survey (1981-1983) [unpublished provisional data]. Cincinnati, OH. 1990.

14. Code of Federal Regulations (CFR). 29:\$1910.1000. 
15. American Conference of Governmental Industrial Hygienists (ACGIH). 2012 TLVs $®$ and BEIs®. Threshold limit values for chemical substances and physical agents and biological exposure indices. Cincinnati, OH; 2012.

16. National Institute for Occupational Safety and Health (NIOSH). Triethylamine. Atlanta, GA: Centers for Disease Control and Prevention, National Institute for Occupational Safety and Health; 2014. International Chemical Safety Card No. 0203. https://www.cdc.gov/niosh/ipcsneng/neng0203.html [Accessed: March 1, 2018]

17. Akesson B, Skerfving S, Mattiasson L. Experimental study on the metabolism of triethylamine in man. Occup Environ Med. 1988; 45(4):262-268.

http://dx.doi.org/10.1136/oem.45.4.262

18. Åkesson B, Vinge E, Skerfving S. Pharmacokinetics of triethylamine and triethylamine-noxide in man. Toxicol Appl Pharmacol. 1989; 100(3):529-538. http://dx.doi.org/10.1016/0041$\underline{008 X(89) 90300-1}$

19. Åkesson B, Skerfving S, Ståhlbom B, Lundh T. Metabolism of triethylamine in polyurethane foam manufacturing workers. Am J Ind Med. 1989; 16(3):255-265.

http://dx.doi.org/10.1002/ajim.4700160304

20. Snyder R. Ethyl Browning's toxicity and metabolism of industrial solvents. Vol. II: Nitrogen and phosphorus solvents. Amsterdam, Netherlands: Elsevier; 1990.

21. Carpenter CP, Smyth Jr H, Shaffer C. The acute toxicity of eihylene imine to small animals. J Ind Hyg Toxicol. 1948; 30(1):2-6.

22. Brieger H, Hodes W. Toxic effects of exposure to vapors of aliphatic amines. AMA Arch Ind Hyg Occup Med. 1951; 3(3):287-291.

23. Tkachev PG. Hygienic assessment of the effect of inhalation of small concentrations of aliphatic ethylamines. Gig Sanit. 1971; 36(9):8.

24. Lynch D, Moorman W, Lewis T, Stober P, Hamlin R, Schueler R. Subchronic inhalation of triethylamine vapor in Fischer-344 rats: Organ system toxicity. Toxicol Ind Health. 1990; 6(34):403-414. http://dx.doi.org/10.1177/074823379000600304

25. Proctor NH, Hughes JP. Chemical hazards of the workplace. Philadelphia, PA: J.B. Lippincott Co.; 1978.

26. Union Carbide Corporation. Initial submission: Primary dermal irritation study of ethylamine, triethylamine, and diethylamine in albino rabbits with cover letter dated 072892. 1986. U.S. Environmental Protection Agency/OTS Public Files, Document No. 86-870001409, Fiche No. 0515571.

27. Hoechst Celanese Corporation. Dermal corrosivity study in rabbits with C-01043 triethylamine (IMO) with attachments and cover letter dated 021390. 1989. U.S. Environmental Protection Agency/OTS Public Files, Doc. No. 86-000000098, Fiche No. 0522354. 
28. Pennwalt Corporation. Eye irritancy in rabbits using triethylamine (final report). 1986. U.S. Environmental Protection Agency/OTS Public Files, Doc. No. 86-870000535, Fiche No. 0513613.

29. Virginia Chemicals. Acute dermal toxicity of triethylamine in rabbits. 1987. U.S. Environmental Protection Agency/OTS Public Files, Document No. 86-870000815, Fiche No. OTS0515253.

30. Union Carbide Corporation. Range finding toxicity studies of triethylamine. 1979. U.S. Environmental Protection Agency/OTS Public Files, Document No. 86-870001448, Fiche No. 0515610 .

31. Union Carbide Corporation. Range finding tests on triethylamine. 1949. U.S. Environmental Protection Agency/OTS Public Files, Document No. 86-870001409, Fiche No. 0515571.

32. Mellerio J, Weale RA. Hazy vision in amine plant operatives. Br J Ind Med. 1966; 23:153154.

33. Åkesson B, Bengtsson M, Florén I. Visual disturbances after industrial triethylamine exposure. Int Arch Occup Environ Health. 1986; 57(4):297-302.

http://dx.doi.org/10.1007/BF00406184

34. Akesson B, Florén I, Skerfving S. Visual disturbances after experimental human exposure to triethylamine. Occup Environ Med. 1985; 42(12):848-850.

http://dx.doi.org/10.1136/oem.42.12.848

35. Reilly MJ, Rosenman KD, Abrams JH, Zhu Z, Tseng C-y, Hertzberg V, Rice C. Ocular effects of exposure to triethylamine in the sand core cold box of a foundry. Occup Environ Med. 1995; 52(5):337-343. http://dx.doi.org/10.1136/oem.52.5.337

36. Ashland Chemical Company. Monitoring surveys: N,n-diethylethanamine, isopropanol, butanol, methanol, acetone, hexane and toluene. 1986. U.S. Environmental Protection Agency/OTS Public Files, Document No. 86 870001686, Fiche No., 0515762.

37. Hansen ES. Cancer mortality among danish molders. Am J Ind Med. 1991; 20(3):401-409. http://dx.doi.org/10.1002/ajim.4700200312

38. Schweinsberg F, Sander J. Cancerogenic nitrosamines consisting of simple aliphatic tertiary amines and nitrite. Hoppe-Seyler's Zeitschrift Für Physiologische Chemie. 1972; 353(2):1671. http://dx.doi.org/10.1515/bchm2.1972.353.2.1671

39. Zeiger E, Anderson B, Haworth S, Lawlor T, Mortelmans K, Speck W. Salmonella mutagenicity tests: III. Results from the testing of 255 chemicals. Environ Mutagen. 1987; 9(S9 S9):61-109.

40. Lindegård B, Mathiasson L, Jönsson JA, Åkesson B. Controlled thermal degradation for the identification and quantification of amine n-oxides in urine. J Chromatogr A. 1990; 514:293-304. http://dx.doi.org/10.1016/S0021-9673(01)89401-2

41. Gorgacz EJ. Occupational cardiac toxicity - acute diethylamine exposures. Cincinnati, OH: National Institute for Occupational Safety and Health; 1987. NIOSH Study No. CAN 339. 
42. Schueler RL. Report of pathologic findings in Fischer 344 rats exposed by inhalation to allylamine, ethylamine, diethylamine, and triethylamine. Unpublished report prepared by Research Pathology Associates, Inc., for Dr. David Groth. National Institute of Occupational Safety and Health; 1984. NIOSH Contract No. 211-83-0020.

43. Brecher G, Schneiderman M. A time-saving device for the counting of reticulocytes. Am J Clin Pathol. 1950; 20(11_ts):1079-1083. http://dx.doi.org/10.1093/ajcp/20.11_ts.1079

44. Maronpot R, Boorman G. Interpretation of rodent hepatocellular proliferative alterations and hepatocellular tumors in chemical safety assessment. Toxicol Pathol. 1982; 10(2):71-78. http://dx.doi.org/10.1177/019262338201000210

45. Boorman GA, Montgomery CA, Jr., Eustis SL, Wolfe MJ, McConnell EE, Hardisty JF. Quality assurance in pathology for rodent carcinogenicity studies. In: Milman HA, Weisburger EK, editors. Handbook of Carcinogen Testing Park Ridge, NJ: Noyes Publications; 1985. p. 345357.

46. Gart JJ, Chu KC, Tarone RE. Statistical issues in interpretation of chronic bioassay tests for carcinogenicity. J Natl Cancer Inst. 1979; 62(4):957-974.

47. Dunnett CW. A multiple comparison procedure for comparing several treatments with a control. J American Stat Assoc. 1955; 50(272):1096-1121.

http://dx.doi.org/10.1080/01621459.1955.10501294

48. Williams DA. The comparison of several dose levels with a zero dose control. Biometrics. 1972; 28(2):519-531. http://dx.doi.org/10.2307/2556164

49. Williams DA. A test for differences between treatment means when several dose levels are compared with a zero dose control. Biometrics. 1971; 27(1):103-117.

$\underline{\text { http://dx.doi.org/10.2307/2528930 }}$

50. Shirley E. A non-parametric equivalent of Williams' test for contrasting increasing dose levels of a treatment. Biometrics. 1977; 33(2):386-389. http://dx.doi.org/10.2307/2529789

51. Williams DA. A note on Shirley's nonparametric test for comparing several dose levels with a zero-dose control. Biometrics. 1986; 42(1):183-186. http://dx.doi.org/10.2307/2531254

52. Dunn OJ. Multiple comparisons using rank sums. Technometrics. 1964; 6(3):241-252. http://dx.doi.org/10.1080/00401706.1964.10490181

53. Jonckheere AR. A distribution-free k-sample test against ordered alternatives. Biometrika. 1954; 41(1/2):133-145. http://dx.doi.org/10.2307/2333011

54. Dixon W, Massey F. Introduction to statistical analysis. New York, NY: McGraw Hill Book Company Inc; 1957. http://dx.doi.org/10.2307/2332898

55. Girard D, Sager D. The use of Markov chains to detect subtle variation in reproductive cycling. Biometrics. 1987; 43(1):225-234. http://dx.doi.org/10.2307/2531963

56. Code of Federal Regulations (CFR). 21:Part 58. 
57. MacGregor JT, Wehr CM, Henika PR, Shelby MD. The in vivo erythrocyte micronucleus test: Measurement at steady state increases assay efficiency and permits integration with toxicity studies. Fundam Appl Toxicol. 1990; 14(3):513-522. http://dx.doi.org/10.1016/0272$\underline{0590(90) 90255-\mathrm{I}}$

58. Jiang X, Buckley L, Morgan K. Pathology of toxic responses to the rd50 concentration of chlorine gas in the nasal passages of rats and mice. Toxicol Appl Pharmacol. 1983; 71(2):225236. http://dx.doi.org/10.1016/0041-008X(83)90339-3

59. Broderson JR, Lindsey JR, Crawford JE. The role of environmental ammonia in respiratory mycoplasmosis of rats. Am J Pathol. 1976; 85(1):115.

60. Kruysse A, Feron VJ, Til HP. Repeated exposure to acetaldehyde vapor: Studies in syrian golden hamsters. Arch Environ Health. 1975; 30(9):449-452.

http://dx.doi.org/10.1080/00039896.1975.10666748

61. Feron V, Kruysse A, Til H, Immel H. Repeated exposure to acrolein vapour: Subacute studies in hamsters, rats and rabbits. Toxicology. 1978; 9(1-2):47-57.

http://dx.doi.org/10.1016/0300-483X(78)90030-6

62. Beard R, Noe J. Aromatic nitro and amino compounds. In: Clayton G, Clayton R, editors. Patty's Industrial Hygiene and Toxicology. 3rd ed. New York, NY: John Wiley and Sons; 1981. p. 213-2489.

63. Steinhagen WH, Swenberg JA, Barrow CS. Acute inhalation toxicity and sensory irritation of dimethylamine. Am Ind Hyg Assoc J. 1982; 43(6):411-417.

http://dx.doi.org/10.1080/15298668291409956

64. Buckley L, Morgan K, Swenberg J, James R, Hamm Jr T, Barrow C. The toxicity of dimethylamine in F-344 rats and B6C3F1 mice following a 1-year inhalation exposure. Toxicol Sci. 1985; 5(2):341-352. http://dx.doi.org/10.1016/0272-0590(85)90082-X

65. Gross E, Patterson D, Morgan K. Effects of acute and chronic dimethylamine exposure on the nasal mucociliary apparatus of f-344 rats. Toxicol Appl Pharmacol. 1987; 90(3):359-376. http://dx.doi.org/10.1016/0041-008X(87)90129-3

66. National Toxicology Program (NTP). Toxicology and carcinogenesis studies of diethylamine (CAS No. 109 89-7) in F344/N rats and B6C3F1 mice (inhalation studies). Research Triangle Park, NC: U.S. Department of Health and Human Services, Public Health Service, National Institutes of Health; 2012. Technical Report Series No. 566. NIH Publication No. 12-5908.

67. Long PH, Leininger JR, Nold JB, Lieuallen WG. Proliferative lesions of bone, cartilage, tooth, and synovium in rats. In: Guides for Toxicologic Pathology. Washington, DC:

STP/ARP/AFIP; 1993.

68. National Toxicology Program (NTP). Toxicology and carcinogenesis studies of C.I. pigment red 3 (CAS No. 2425 85-6) in F344/N rats and B6C3F1 mice (feed studies). Research Triangle Park, NC: U.S. Department of Health and Human Services, Public Health Service, National Institutes of Health; 1992. Technical Report Series No. 407. NIH Publication No. 92-3138. 
69. National Toxicology Program (NTP). Toxicology and Carcinogenesis Studies of 1,2Epoxybutane (CAS No. 106 88-7) in F344/N Rats and B6C3F1 Mice (Inhalation Studies). Research Triangle Park, NC: U.S. Department of Health and Human Services, Public Health Service, National Institutes of Health; 1988. Technical Report Series No. 329. NIH Publication No. 88-2585.

70. Union Carbide Corporation. Amine-induced blue-gray vision: Brief review. Danbury, CT; 1984.

71. Albrecht WN, Stephenson RL. Health hazards of tertiary amine catalysts. Scand J Work Environ Health. 1988; 14(4):209-219. http://dx.doi.org/10.5271/sjweh.1930

72. Dernehl CU. Health hazards associated with polyurethane foams. J Occup Environ Med. 1966; 8(2):59-62.

73. Järvinen P, Engström K, Riihimäki V, Ruusuvaara P, Setälä K. Effects of experimental exposure to triethylamine on vision and the eye. Occup Environ Med. 1999; 56(1):1-5. http://dx.doi.org/10.1136/oem.56.1.1

74. Potts AM, Rouse EF, Eiferman RA, Au PC. An unusual type of keratopathy observed in polyurethane workers and its reproduction in experimental animals. Am J Ind Med. 1986; 9(2):203-213. http://dx.doi.org/10.1002/ajim.4700090211

75. Wagoner MD. Chemical injuries of the eye: Current concepts in pathophysiology and therapy. Surv Ophthalmol. 1997; 41(4):275-313. http://dx.doi.org/10.1016/S0039$\underline{6257(96) 00007-0}$

76. Paterson CA, Pfister RR, Levinson RA. Aqueous humor Ph changes after experimental alkali burns. Am J Ophthalmol. 1975; 79(3):414-419. http://dx.doi.org/10.1016/0002-9394(75)90614-5

77. Paterson CA, Pfister RR. Intraocular pressure changes after alkali burns. Arch Ophthalmol. 1974; 91(3):211-218. http://dx.doi.org/10.1001/archopht.1974.03900060219014

78. Pouchert CJ. The Aldrich library of FT-IR spectra. Milwaukee, WI: Aldrich Chemical Company Inc.; 1997.

79. Pouchert CJ. The Aldrich library of infrared spectra. Pouchert CJ, editor. Milwaukee, WI: Aldrich Chemical Company Inc.; 1981. 


\section{Appendix A. Summary of Nonneoplastic Lesions in Rats and Mice}

\section{Tables}

Table A-1. Summary of the Incidence of Nonneoplastic Lesions in Male Rats in the Three-month Inhalation Study of Triethylamine

Table A-2. Summary of the Incidence of Nonneoplastic Lesions in Female Rats in the Three-month Inhalation Study of Triethylamine A-4

Table A-3. Summary of the Incidence of Nonneoplastic Lesions in Male Mice in the Three-month Inhalation Study of Triethylamine

Table A-4. Summary of the Incidence of Nonneoplastic Lesions in Female Mice in the Three-month Inhalation Study of Triethylamine 
Table A-1. Summary of the Incidence of Nonneoplastic Lesions in Male Rats in the Three-month Inhalation Study of Triethylamine ${ }^{a}$

\begin{tabular}{|c|c|c|c|c|c|c|}
\hline & $\begin{array}{l}\text { Chamber } \\
\text { Control }\end{array}$ & $12.5 \mathrm{ppm}$ & 25 ppm & $50 \mathrm{ppm}$ & 100 ppm & $200 \mathrm{ppm}$ \\
\hline \multicolumn{7}{|l|}{ Disposition Summary } \\
\hline Animals initially in study & 10 & 10 & 10 & 10 & 10 & 10 \\
\hline \multicolumn{7}{|l|}{ Survivors } \\
\hline Terminal kill & 10 & 10 & 10 & 10 & 10 & 10 \\
\hline Animals examined microscopically & 10 & 10 & 10 & 10 & 10 & 10 \\
\hline \multicolumn{7}{|l|}{ Alimentary System } \\
\hline Liver & $(10)$ & $(10)$ & $(10)$ & $(10)$ & $(10)$ & $(10)$ \\
\hline Clear cell focus & - & - & - & - & $1(10 \%)$ & - \\
\hline Hepatodiaphragmatic nodule & - & $3(30 \%)$ & $4(40 \%)$ & - & - & $1(10 \%)$ \\
\hline Inflammation & - & - & - & $2(20 \%)$ & - & - \\
\hline Bile duct, hyperplasia, focal & - & - & $1(10 \%)$ & - & - & - \\
\hline \multicolumn{7}{|l|}{ Cardiovascular System } \\
\hline None & - & - & - & - & - & - \\
\hline \multicolumn{7}{|l|}{ Endocrine System } \\
\hline None & - & - & - & - & - & - \\
\hline \multicolumn{7}{|l|}{ General Body System } \\
\hline None & - & - & - & - & - & - \\
\hline \multicolumn{7}{|l|}{ Genital System } \\
\hline Prostate & $(10)$ & - & - & - & - & $(10)$ \\
\hline Inflammation, suppurative & $1(10 \%)$ & - & - & - & - & - \\
\hline \multicolumn{7}{|l|}{ Hematopoietic System } \\
\hline Lymph node, mediastinal & (7) & - & - & - & - & (2) \\
\hline Ectasia & $1(14 \%)$ & - & - & - & - & - \\
\hline \multicolumn{7}{|l|}{ Integumentary System } \\
\hline None & - & - & - & - & - & - \\
\hline \multicolumn{7}{|l|}{ Musculoskeletal System } \\
\hline None & - & - & - & - & - & - \\
\hline \multicolumn{7}{|l|}{ Nervous System } \\
\hline None & - & - & - & - & - & - \\
\hline \multicolumn{7}{|l|}{ Respiratory System } \\
\hline Larynx & $(10)$ & $(10)$ & $(10)$ & (10) & $(10)$ & $(10)$ \\
\hline Infiltration cellular, mononuclear cell & - & $3(30 \%)$ & - & $1(10 \%)$ & - & - \\
\hline Inflammation & - & - & - & $1(10 \%)$ & - & - \\
\hline
\end{tabular}


Triethylamine, NTP TOX 78

\begin{tabular}{|c|c|c|c|c|c|c|}
\hline & $\begin{array}{l}\text { Chamber } \\
\text { Control }\end{array}$ & $12.5 \mathrm{ppm}$ & $25 \mathrm{ppm}$ & $50 \mathrm{ppm}$ & 100 ppm & 200 ppm \\
\hline $\begin{array}{l}\text { Glands, inflammation, } \\
\text { suppurative }\end{array}$ & - & - & - & - & $1(10 \%)$ & - \\
\hline $\begin{array}{l}\text { Squamous epithelium, } \\
\text { metaplasia }\end{array}$ & - & $1(10 \%)$ & - & $1(10 \%)$ & - & - \\
\hline Lung & $(10)$ & (10) & $(10)$ & $(10)$ & (10) & $(10)$ \\
\hline Inflammation, focal & - & - & - & $1(10 \%)$ & - & - \\
\hline Metaplasia, osseous & $2(20 \%)$ & - & $2(20 \%)$ & $2(20 \%)$ & $1(10 \%)$ & - \\
\hline $\begin{array}{l}\text { Alveolar epithelium, } \\
\text { hyperplasia }\end{array}$ & $1(10 \%)$ & - & - & - & - & - \\
\hline $\begin{array}{l}\text { Alveolar epithelium, infiltration } \\
\text { cellular, polymorphonuclear }\end{array}$ & $1(10 \%)$ & - & - & - & - & - \\
\hline $\begin{array}{l}\text { Alveolus, infiltration cellular, } \\
\text { histiocyte }\end{array}$ & $4(40 \%)$ & $5(50 \%)$ & $3(30 \%)$ & $2(20 \%)$ & $6(60 \%)$ & $6(60 \%)$ \\
\hline Nose & (10) & $(10)$ & $(10)$ & $(10)$ & (10) & $(10)$ \\
\hline Olfactory epithelium, atrophy & - & - & - & $10(100 \%)$ & $10(100 \%)$ & $10(100 \%)$ \\
\hline $\begin{array}{l}\text { Respiratory epithelium, } \\
\text { accumulation, hyaline droplet }\end{array}$ & - & - & - & - & - & $3(30 \%)$ \\
\hline $\begin{array}{l}\text { Respiratory epithelium, } \\
\text { hyperplasia }\end{array}$ & - & $3(30 \%)$ & $9(90 \%)$ & $9(90 \%)$ & $10(100 \%)$ & $10(100 \%)$ \\
\hline \multicolumn{7}{|l|}{ Special Senses System } \\
\hline Eye & (9) & $(10)$ & $(10)$ & $(10)$ & $(10)$ & $(10)$ \\
\hline Cornea, mineralization & - & - & - & - & $1(10 \%)$ & $3(30 \%)$ \\
\hline Cornea, necrosis & - & - & - & - & - & $1(10 \%)$ \\
\hline Cornea, epithelium, vacuolation & - & - & - & - & - & $2(20 \%)$ \\
\hline Retina, degeneration & - & - & - & $1(10 \%)$ & - & - \\
\hline Harderian gland & (10) & - & - & - & (1) & $(10)$ \\
\hline Infiltration cellular, mononuclear cell & $1(10 \%)$ & - & - & - & $1(100 \%)$ & $1(10 \%)$ \\
\hline \multicolumn{7}{|l|}{ Urinary System } \\
\hline Kidney & (10) & (10) & (10) & (10) & (10) & (10) \\
\hline Nephropathy & $1(10 \%)$ & - & $1(10 \%)$ & - & $1(10 \%)$ & - \\
\hline Renal tubule, cyst & - & - & - & $1(10 \%)$ & - & - \\
\hline
\end{tabular}

aNumber of animals examined microscopically at the site and the number of animals with lesion. 
Table A-2. Summary of the Incidence of Nonneoplastic Lesions in Female Rats in the Three-month Inhalation Study of Triethylamine ${ }^{a}$

\begin{tabular}{|c|c|c|c|c|c|c|}
\hline & $\begin{array}{l}\text { Chamber } \\
\text { Control }\end{array}$ & $12.5 \mathrm{ppm}$ & 25 ppm & $50 \mathrm{ppm}$ & 100 ppm & 200 ppm \\
\hline \multicolumn{7}{|l|}{ Disposition Summary } \\
\hline Animals initially in study & 10 & 10 & 10 & 10 & 10 & 10 \\
\hline \multicolumn{7}{|l|}{ Survivors } \\
\hline Terminal euthanasia & 10 & 10 & 10 & 10 & 10 & 10 \\
\hline Animals examined microscopically & 10 & 10 & 10 & 10 & 10 & 10 \\
\hline \multicolumn{7}{|l|}{ Alimentary System } \\
\hline Intestine small, jejunum & $(10)$ & (10) & $(10)$ & $(10)$ & $(10)$ & $(10)$ \\
\hline Serosa, inflammation, chronic & - & $1(10 \%)$ & - & - & - & - \\
\hline Liver & $(10)$ & $(10)$ & $(10)$ & $(10)$ & $(10)$ & $(10)$ \\
\hline Hepatodiaphragmatic nodule & $1(10 \%)$ & - & - & $1(10 \%)$ & $1(10 \%)$ & $2(20 \%)$ \\
\hline Inflammation & $1(10 \%)$ & - & $2(20 \%)$ & $2(20 \%)$ & $1(10 \%)$ & $1(10 \%)$ \\
\hline Inflammation, chronic & - & $1(10 \%)$ & - & - & - & - \\
\hline Serosa, fibrosis & - & - & - & - & $1(10 \%)$ & - \\
\hline Mesentery & - & - & (2) & (1) & - & - \\
\hline Fat, necrosis, chronic & - & - & $2(100 \%)$ & $1(100 \%)$ & - & - \\
\hline Pancreas & (10) & - & - & - & - & $(10)$ \\
\hline Atrophy & $1(10 \%)$ & - & - & - & - & - \\
\hline Stomach, glandular & (10) & $(10)$ & $(10)$ & $(10)$ & $(10)$ & $(10)$ \\
\hline Cyst & - & - & - & - & - & $1(10 \%)$ \\
\hline \multicolumn{7}{|l|}{ Cardiovascular System } \\
\hline Heart & (10) & - & - & - & (1) & $(10)$ \\
\hline Pericardium, fibrosis & - & - & - & - & $1(100 \%)$ & - \\
\hline $\begin{array}{l}\text { Pericardium, infiltration cellular, } \\
\text { mononuclear cell }\end{array}$ & - & - & - & - & $1(100 \%)$ & - \\
\hline \multicolumn{7}{|l|}{ Endocrine System } \\
\hline None & - & - & - & - & - & - \\
\hline \multicolumn{7}{|l|}{ General Body System } \\
\hline None & - & - & - & - & - & - \\
\hline \multicolumn{7}{|l|}{ Genital System } \\
\hline Ovary & $(10)$ & - & (1) & (1) & (1) & $(10)$ \\
\hline Metaplasia, lipocyte & $1(10 \%)$ & - & - & - & - & - \\
\hline Periovarian tissue, cyst & - & - & $1(100 \%)$ & $1(100 \%)$ & $1(100 \%)$ & $1(10 \%)$ \\
\hline
\end{tabular}


Triethylamine, NTP TOX 78

\begin{tabular}{|c|c|c|c|c|c|c|}
\hline & $\begin{array}{l}\text { Chamber } \\
\text { Control }\end{array}$ & $12.5 \mathrm{ppm}$ & $25 \mathrm{ppm}$ & $50 \mathrm{ppm}$ & 100 ppm & 200 ppm \\
\hline \multicolumn{7}{|l|}{ Hematopoietic System } \\
\hline Lymph node & - & (1) & - & (1) & (1) & - \\
\hline $\begin{array}{l}\text { Pancreatic, hyperplasia, } \\
\text { histiocytic }\end{array}$ & - & $1(100 \%)$ & - & $1(100 \%)$ & $1(100 \%)$ & - \\
\hline \multicolumn{7}{|l|}{ Integumentary System } \\
\hline None & - & - & - & - & - & - \\
\hline \multicolumn{7}{|l|}{ Musculoskeletal System } \\
\hline None & - & - & - & - & - & - \\
\hline \multicolumn{7}{|l|}{ Nervous System } \\
\hline None & - & - & - & - & - & - \\
\hline \multicolumn{7}{|l|}{ Respiratory System } \\
\hline Larynx & (9) & $(10)$ & $(10)$ & $(10)$ & $(10)$ & $(10)$ \\
\hline Granuloma & - & - & - & $1(10 \%)$ & - & - \\
\hline Infiltration, cellular, mononuclear cell & - & $1(10 \%)$ & $1(10 \%)$ & - & - & - \\
\hline Inflammation & - & $1(10 \%)$ & - & - & - & - \\
\hline Lung & $(10)$ & $(10)$ & $(10)$ & $(10)$ & $(10)$ & $(10)$ \\
\hline Inflammation, focal & - & - & - & - & - & $1(10 \%)$ \\
\hline Metaplasia, osseous & - & - & - & - & - & $1(10 \%)$ \\
\hline Mineralization & - & - & - & - & - & $1(10 \%)$ \\
\hline Alveolar epithelium, hyperplasia & $1(10 \%)$ & - & - & - & - & - \\
\hline $\begin{array}{l}\text { Alveolus, infiltration cellular, } \\
\text { histiocyte }\end{array}$ & $2(20 \%)$ & $1(10 \%)$ & $4(40 \%)$ & $4(40 \%)$ & $7(70 \%)$ & $7(70 \%)$ \\
\hline Nose & $(10)$ & $(10)$ & (10) & (10) & (10) & $(10)$ \\
\hline Foreign body & $1(10 \%)$ & - & - & - & - & - \\
\hline Inflammation, chronic & - & - & - & $1(10 \%)$ & $2(20 \%)$ & - \\
\hline Olfactory epithelium, atrophy & - & - & $4(40 \%)$ & $10(100 \%)$ & $10(100 \%)$ & $10(100 \%)$ \\
\hline $\begin{array}{l}\text { Respiratory epithelium, } \\
\text { accumulation, hyaline droplet }\end{array}$ & - & - & - & - & $1(10 \%)$ & - \\
\hline Respiratory epithelium, hyperplasia & - & $3(30 \%)$ & $9(90 \%)$ & $10(100 \%)$ & $10(100 \%)$ & $10(100 \%)$ \\
\hline Pleura & - & - & - & - & (1) & - \\
\hline Hyperplasia & - & - & - & - & $1(100 \%)$ & - \\
\hline Inflammation, chronic & - & - & - & - & $1(100 \%)$ & - \\
\hline \multicolumn{7}{|l|}{ Special Senses System } \\
\hline Eye & $(10)$ & $(10)$ & $(10)$ & $(10)$ & $(10)$ & $(10)$ \\
\hline $\begin{array}{l}\text { Anterior chamber, infiltration } \\
\text { cellular, macrophage }\end{array}$ & - & - & - & - & - & $1(10 \%)$ \\
\hline
\end{tabular}


Triethylamine, NTP TOX 78

\begin{tabular}{lcccccc}
\hline & $\begin{array}{c}\text { Chamber } \\
\text { Control }\end{array}$ & $\mathbf{1 2 . 5} \mathbf{~ p p m}$ & $\mathbf{2 5} \mathbf{~ p p m}$ & $\mathbf{5 0} \mathbf{~ p p m}$ & $\mathbf{1 0 0} \mathbf{~ p p m}$ & $\mathbf{2 0 0} \mathbf{~ p p m}$ \\
\hline Cornea, edema & - & - & - & - & - & $1(10 \%)$ \\
Cornea, inflammation, chronic & - & - & - & - & - & $1(10 \%)$ \\
Cornea, mineralization & - & - & - & - & - & $2(20 \%)$ \\
Cornea, necrosis & - & - & - & - & - & $1(10 \%)$ \\
Cornea, vesicle, subepithelial & - & - & - & - & - & $3(30 \%)$ \\
Cornea, epithelium, ulcer & - & - & - & - & - & $1(10 \%)$ \\
Lens, cataract & - & - & - & - & - & $1(10 \%)$ \\
Retina, degeneration & - & - & $1(10 \%)$ & - & $2(20 \%)$ & $1(10 \%)$ \\
Retina, dysplasia & - & - & - & - & - & $1(10 \%)$ \\
Harderian gland & $(10)$ & - & - & - & - & $(10)$ \\
Infiltration cellular, mononuclear cell & $1(10 \%)$ & - & - & - & - & $3(30 \%)$ \\
\hline
\end{tabular}

\section{Urinary System}

None

aNumber of animals examined microscopically at the site and the number of animals with lesion. 
Table A-3. Summary of the Incidence of Nonneoplastic Lesions in Male Mice in the Three-month Inhalation Study of Triethylamine ${ }^{a}$

\begin{tabular}{lcccccc}
\hline & $\begin{array}{c}\text { Chamber } \\
\text { Control }\end{array}$ & $\mathbf{1 2 . 5} \mathbf{~ p p m}$ & $\mathbf{2 5} \mathbf{~ p p m}$ & $\mathbf{5 0} \mathbf{~ p p m}$ & $\mathbf{1 0 0} \mathbf{~ p p m}$ & $\mathbf{2 0 0} \mathbf{~ p p m}$ \\
\hline $\begin{array}{l}\text { Disposition Summary } \\
\text { Animals initially in study }\end{array}$ & 10 & 10 & 10 & 10 & 10 & 10 \\
$\begin{array}{l}\text { Survivors } \\
\quad \text { Terminal euthanasia }\end{array}$ & 10 & 10 & 10 & 10 & 10 & 10 \\
Animals examined microscopically & 10 & 10 & 10 & 10 & 10 & 10 \\
\hline
\end{tabular}

Alimentary System

None

Cardiovascular System

None

Endocrine System

None

General Body System

None

Genital System

None

Hematopoietic System

None

Integumentary System

None

Musculoskeletal System

None

Nervous System

None

\section{Respiratory System}

Lung

Infiltration cellular, histiocyte

(10)

$$
\text { (10) }
$$

(10)

(10)

(10)

(10)

Inflammation, chronic active

$1(10 \%)$

$1(10 \%)$

Nose

(10)

(10)

(10)

(10)

(10)

Inflammation, suppurative

Olfactory epithelium, accumulation, hyaline droplet

Olfactory epithelium, atrophy

$-\quad-$

-

Olfactory epithelium, vacuolization cytoplasmic 
Triethylamine, NTP TOX 78

\begin{tabular}{|c|c|c|c|c|c|c|}
\hline & $\begin{array}{c}\text { Chamber } \\
\text { Control }\end{array}$ & $12.5 \mathrm{ppm}$ & $25 \mathrm{ppm}$ & $50 \mathrm{ppm}$ & 100 ppm & 200 ppm \\
\hline $\begin{array}{l}\text { Respiratory epithelium, } \\
\text { accumulation, hyaline droplet }\end{array}$ & - & - & - & - & $9(90 \%)$ & - \\
\hline $\begin{array}{l}\text { Respiratory epithelium, metaplasia, } \\
\text { squamous }\end{array}$ & - & - & - & - & - & $10(100 \%)$ \\
\hline Turbinate, atrophy & - & - & - & - & - & $5(50 \%)$ \\
\hline Turbinate, hyperostosis & - & $10(100 \%)$ & $9(90 \%)$ & $10(100 \%)$ & $10(100 \%)$ & $10(100 \%)$ \\
\hline Turbinate, necrosis & - & - & - & - & - & $10(100 \%)$ \\
\hline \multicolumn{7}{|l|}{ Special Senses System } \\
\hline None & - & - & - & - & - & - \\
\hline \multicolumn{7}{|l|}{ Urinary System } \\
\hline None & - & - & - & - & - & - \\
\hline
\end{tabular}

${ }^{a}$ Number of animals examined microscopically at the site and the number of animals with lesion. 
Table A-4. Summary of the Incidence of Nonneoplastic Lesions in Female Mice in the Three-month Inhalation Study of Triethylamine ${ }^{a}$

\begin{tabular}{|c|c|c|c|c|c|c|}
\hline & $\begin{array}{c}\text { Chamber } \\
\text { Control }\end{array}$ & $12.5 \mathrm{ppm}$ & $25 \mathrm{ppm}$ & $50 \mathrm{ppm}$ & 100 ppm & $200 \mathrm{ppm}$ \\
\hline \multicolumn{7}{|l|}{ Disposition Summary } \\
\hline Animals initially in study & 10 & 10 & 10 & 10 & 10 & 10 \\
\hline \multicolumn{7}{|l|}{ Survivors } \\
\hline Terminal kill & 10 & 10 & 10 & 10 & 10 & 10 \\
\hline Animals examined microscopically & 10 & 10 & 10 & 10 & 10 & 10 \\
\hline \multicolumn{7}{|l|}{ Alimentary System } \\
\hline None & - & - & - & - & - & - \\
\hline \multicolumn{7}{|l|}{ Cardiovascular System } \\
\hline None & - & - & - & - & - & - \\
\hline \multicolumn{7}{|l|}{ Endocrine System } \\
\hline None & - & - & - & - & - & - \\
\hline \multicolumn{7}{|l|}{ General Body System } \\
\hline None & - & - & - & - & - & - \\
\hline \multicolumn{7}{|l|}{ Genital System } \\
\hline Uterus & (10) & - & - & - & (1) & $(10)$ \\
\hline Decidual reaction & - & - & - & - & $1(100 \%)$ & - \\
\hline
\end{tabular}

\section{Hematopoietic System}

None

Integumentary System

None

Musculoskeletal System

None

Nervous System

None

\section{Respiratory System}

Nose

Inflammation, suppurative

Olfactory epithelium, accumulation, hyaline droplet

Olfactory epithelium, atrophy

Olfactory epithelium, vacuolization cytoplasmic

Respiratory epithelium, accumulation, hyaline droplet

$\begin{array}{cccccc}(10) & (10) & (10) & (10) & (10) & (10) \\ - & - & - & - & - & 1(10 \%) \\ - & - & - & 7(70 \%) & 10(100 \%) & 8(80 \%) \\ - & - & - & 10(100 \%) & 10(100 \%) & 10(100 \%) \\ - & - & - & 5(50 \%) & - & - \\ - & - & - & 7(70 \%) & 10(100 \%) & 8(80 \%)\end{array}$


Triethylamine, NTP TOX 78

\begin{tabular}{lcccccc}
\hline & $\begin{array}{c}\text { Chamber } \\
\text { Control }\end{array}$ & $\mathbf{1 2 . 5} \mathbf{~ p p m}$ & $\mathbf{2 5} \mathbf{~ p p m}$ & $\mathbf{5 0} \mathbf{~ p p m}$ & $\mathbf{1 0 0} \mathbf{~ p p m}$ & $\mathbf{2 0 0} \mathbf{~ p p m}$ \\
\hline $\begin{array}{l}\text { Respiratory epithelium, metaplasia, } \\
\text { squamous }\end{array}$ & - & - & - & - & - & $9(90 \%)$ \\
$\quad \begin{array}{l}\text { Turbinate, atrophy } \\
\text { Turbinate, hyperostosis }\end{array}$ & - & - & - & - & - & $3(30 \%)$ \\
$\quad$ Turbinate, necrosis & - & $8(80 \%)$ & $10(100 \%)$ & $10(100 \%)$ & $9(90 \%)$ & $10(100 \%)$ \\
\hline Special Senses System & - & - & - & - & - & $10(100 \%)$ \\
None & - & - & - & - & - & - \\
\hline Urinary System & - & & & & & \\
None & - & - & - & - & - & - \\
\hline aNumber of animals examined microscopically at the site and the number of animals with lesion.
\end{tabular}




\section{Appendix B. Genetic Toxicology}

\section{Tables}

Table B-1. Mutagenicity of Triethylamine in Bacterial Tester Strains

B-2

Table B-2. Frequency of Micronuclei in Peripheral Blood Erythrocytes of Mice

Following Treatment with Triethylamine by Inhalation for Three Months 
Triethylamine, NTP TOX 78

Table B-1. Mutagenicity of Triethylamine in Bacterial Tester Strains ${ }^{\text {a }}$

\begin{tabular}{|c|c|c|c|c|c|c|c|}
\hline Strain & $\begin{array}{c}\text { Dose } \\
(\mu \mathrm{g} / \text { plate })\end{array}$ & $\begin{array}{c}\text { Without } \\
\text { S9 }\end{array}$ & $\begin{array}{c}\text { Without } \\
\text { S9 }\end{array}$ & $\begin{array}{c}\text { With } 10 \% \\
\text { Hamster S9 }\end{array}$ & $\begin{array}{l}\text { With } 10 \% \\
\text { Hamster S9 }\end{array}$ & $\begin{array}{c}\text { With } 10 \% \\
\text { Rat S9 }\end{array}$ & $\begin{array}{c}\text { With } 10 \% \\
\text { Rat S9 }\end{array}$ \\
\hline \multicolumn{8}{|l|}{ TA100 } \\
\hline & 0 & $125 \pm 1$ & $104 \pm 5$ & $160 \pm 13$ & $117 \pm 5$ & $142 \pm 6$ & $127 \pm 10$ \\
\hline & 100 & $114 \pm 7$ & $117 \pm 10$ & $125 \pm 10$ & $123 \pm 3$ & $127 \pm 6$ & $112 \pm 9$ \\
\hline & 333 & $133 \pm 10$ & $115 \pm 15$ & $147 \pm 1$ & $158 \pm 5$ & $127 \pm 12$ & $113 \pm 3$ \\
\hline & 1,000 & $110 \pm 4$ & $113 \pm 15$ & $138 \pm 7$ & $128 \pm 11$ & $125 \pm 17$ & $111 \pm 8$ \\
\hline & 3,333 & $112 \pm 5$ & $92 \pm 7$ & $140 \pm 7$ & $138 \pm 15$ & $119 \pm 15$ & $89 \pm 3$ \\
\hline & 10,000 & Toxic & Toxic & $129 \pm 1$ & Toxic & $120 \pm 31$ & Toxic \\
\hline Trial summary & & Negative & Negative & Negative & Equivocal & Negative & Negative \\
\hline Positive control ${ }^{\mathrm{b}}$ & & $277 \pm 18$ & $419 \pm 13$ & $1,100 \pm 19$ & $778 \pm 10$ & $688 \pm 39$ & $335 \pm 6$ \\
\hline \multicolumn{8}{|l|}{ TA1535 } \\
\hline & 0 & $27 \pm 1$ & $32 \pm 2$ & $33 \pm 3$ & $35 \pm 4$ & $31 \pm 3$ & $24 \pm 1$ \\
\hline & 100 & $21 \pm 3$ & $30 \pm 4$ & $26 \pm 3$ & $26 \pm 3$ & $25 \pm 3$ & $22 \pm 1$ \\
\hline & 333 & $22 \pm 4$ & $24 \pm 2$ & $25 \pm 2$ & $30 \pm 3$ & $23 \pm 3$ & $24 \pm 2$ \\
\hline & 1,000 & $22 \pm 2$ & $32 \pm 5$ & $25 \pm 1$ & $33 \pm 11$ & $22 \pm 2$ & $18 \pm 2$ \\
\hline & 3,333 & $20 \pm 4$ & $21 \pm 4$ & $24 \pm 1$ & $42 \pm 5$ & $17 \pm 2$ & $17 \pm 2$ \\
\hline & 10,000 & Toxic & Toxic & $27 \pm 6$ & Toxic & $15 \pm 4$ & $4 \pm 2$ \\
\hline Trial summary & & Negative & Negative & Negative & Negative & Negative & Negative \\
\hline Positive control & & $315 \pm 15$ & $379 \pm 22$ & $357 \pm 18$ & $356 \pm 53$ & $260 \pm 8$ & $120 \pm 13$ \\
\hline \multicolumn{8}{|l|}{ TA1537 } \\
\hline & 0 & $4 \pm 1$ & $6 \pm 1$ & $7 \pm 0$ & $7 \pm 1$ & $9 \pm 2$ & $15 \pm 1$ \\
\hline & 100 & $3 \pm 1$ & $8 \pm 1$ & $7 \pm 1$ & $6 \pm 1$ & $12 \pm 2$ & $9 \pm 0$ \\
\hline & 333 & $5 \pm 1$ & $8 \pm 2$ & $4 \pm 1$ & $6 \pm 1$ & $11 \pm 2$ & $6 \pm 0$ \\
\hline & 1,000 & $4 \pm 1$ & $5 \pm 1$ & $5 \pm 1$ & $9 \pm 3$ & $11 \pm 3$ & $9 \pm 1$ \\
\hline & 3,333 & $6 \pm 2$ & $6 \pm 1$ & $8 \pm 3$ & $8 \pm 1$ & $6 \pm 1$ & $5 \pm 2$ \\
\hline & 10,000 & Toxic & Toxic & $7 \pm 1$ & $3 \pm 2$ & $7 \pm 1$ & $2 \pm 0$ \\
\hline Trial summary & & Negative & Negative & Negative & Negative & Negative & Negative \\
\hline Positive control & & $110 \pm 7$ & $277 \pm 25$ & $446 \pm 16$ & $454 \pm 18$ & $217 \pm 5$ & $204 \pm 15$ \\
\hline \multicolumn{8}{|l|}{ TA98 } \\
\hline & 0 & $22 \pm 2$ & $18 \pm 4$ & $32 \pm 2$ & $26 \pm 3$ & $34 \pm 3$ & $33 \pm 4$ \\
\hline & 100 & $20 \pm 2$ & $29 \pm 5$ & $31 \pm 5$ & $35 \pm 5$ & $33 \pm 4$ & $26 \pm 5$ \\
\hline & 333 & $18 \pm 1$ & $18 \pm 2$ & $34 \pm 4$ & $32 \pm 6$ & $25 \pm 6$ & $26 \pm 3$ \\
\hline & 1,000 & $20 \pm 1$ & $19 \pm 2$ & $31 \pm 6$ & $24 \pm 2$ & $26 \pm 4$ & $29 \pm 1$ \\
\hline & 3,333 & $23 \pm 7$ & $12 \pm 1$ & $28 \pm 4$ & $34 \pm 4$ & $26 \pm 1$ & $15 \pm 5$ \\
\hline & 10,000 & Toxic & Toxic & $30 \pm 0$ & Toxic & $22 \pm 3$ & Toxic \\
\hline
\end{tabular}




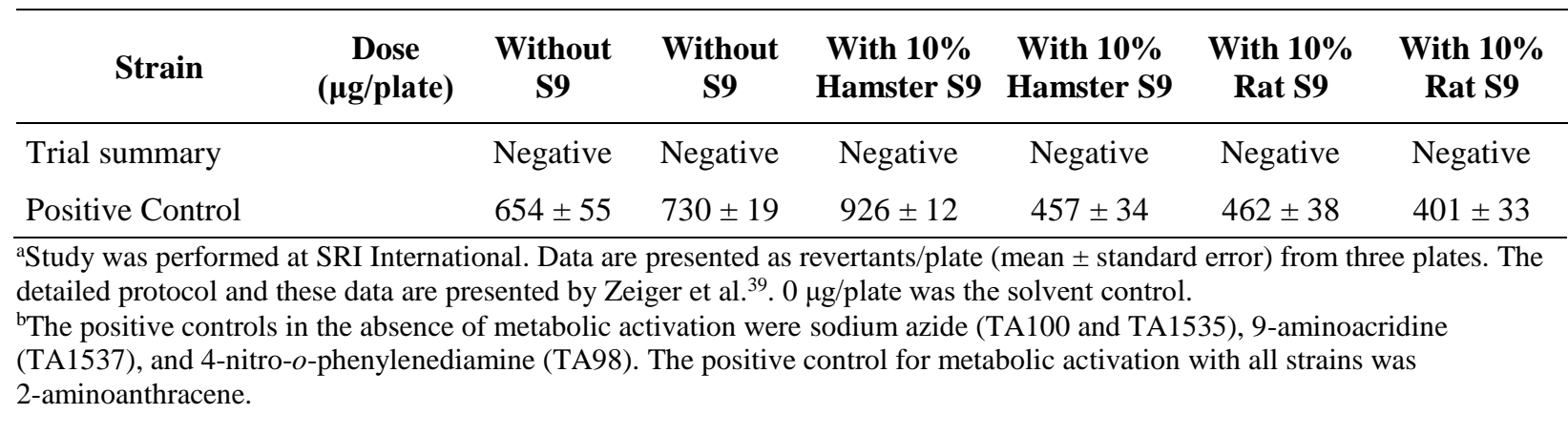

Table B-2. Frequency of Micronuclei in Peripheral Blood Erythrocytes of Mice Following Treatment with Triethylamine by Inhalation for Three Months ${ }^{\text {a }}$

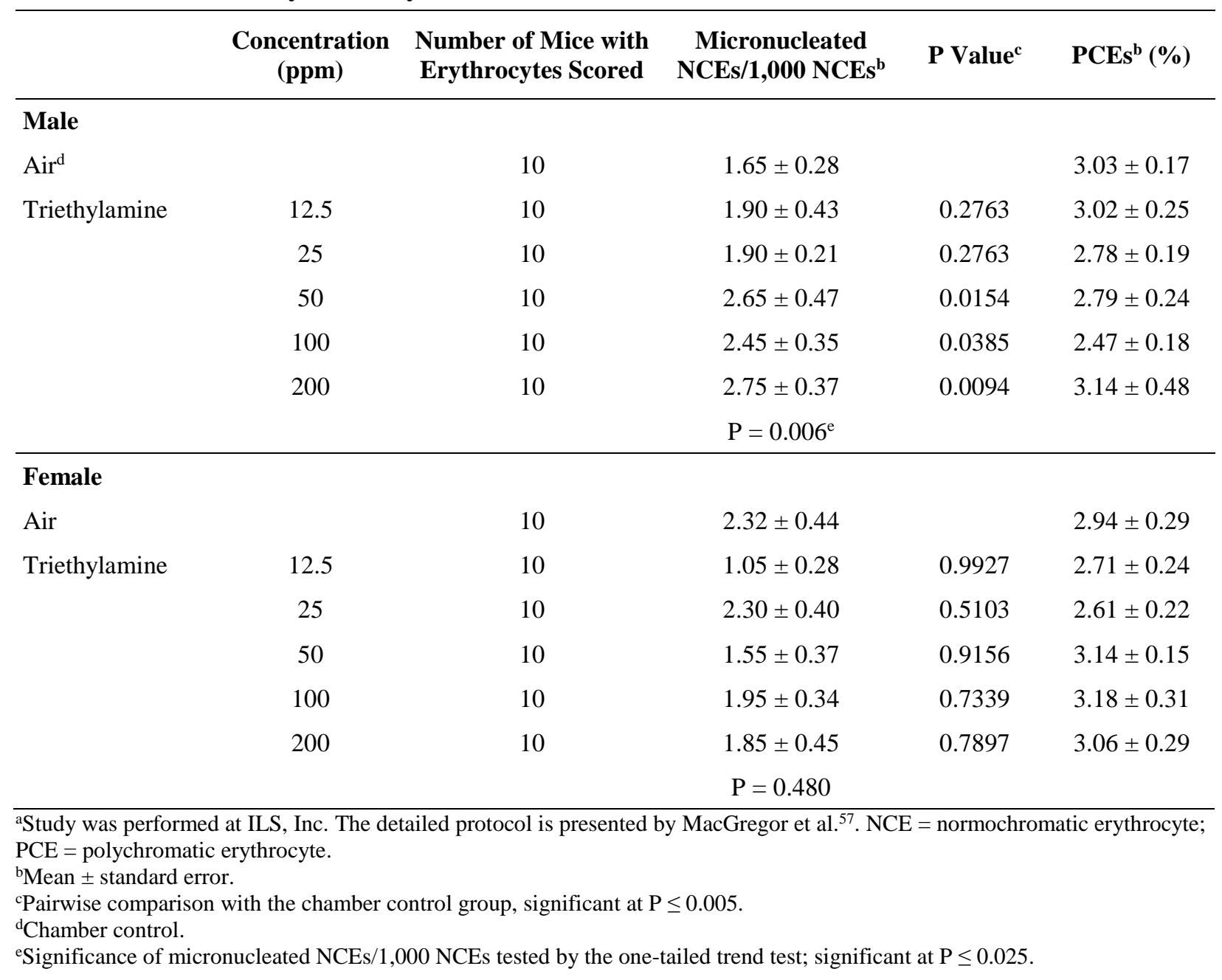




\section{Appendix C. Clinical Pathology Results}

\section{Tables}

Table C-1. Clinical Pathology Data for Rats in the Three-month Inhalation Study of

Triethylamine.....

Table C-2. Hematology Data for Mice in the Three-month Inhalation Study of

Triethylamine. 
Triethylamine, NTP TOX 78

Table C-1. Clinical Pathology Data for Rats in the Three-month Inhalation Study of Triethylamine ${ }^{\text {a }}$

\begin{tabular}{|c|c|c|c|c|c|c|}
\hline & $\begin{array}{l}\text { Chamber } \\
\text { Control }\end{array}$ & $12.5 \mathrm{ppm}$ & 25 ppm & 50 ppm & 100 ppm & 200 ppm \\
\hline \multicolumn{7}{|l|}{ Male } \\
\hline \multicolumn{7}{|l|}{ Hematology } \\
\hline \multicolumn{7}{|l|}{$\mathbf{n}$} \\
\hline Day 3 & 10 & 10 & 10 & 10 & 10 & 10 \\
\hline Day 23 & 10 & 10 & 10 & 10 & 9 & 10 \\
\hline Week 14 & 9 & 10 & 9 & 10 & 10 & 10 \\
\hline \multicolumn{7}{|c|}{ Hematocrit (spun) (\%) } \\
\hline Day 3 & $47.0 \pm 0.4$ & $46.1 \pm 0.7$ & $45.8 \pm 0.5$ & $45.0 \pm 0.4^{*}$ & $46.6 \pm 0.7$ & $47.4 \pm 0.4$ \\
\hline Day 23 & $47.3 \pm 0.3$ & $47.7 \pm 0.4$ & $47.2 \pm 0.5$ & $47.6 \pm 0.3$ & $47.8 \pm 0.4$ & $48.3 \pm 0.5$ \\
\hline Week 14 & $49.0 \pm 0.5$ & $48.0 \pm 0.3$ & $48.8 \pm 0.5$ & $49.1 \pm 0.5$ & $49.0 \pm 0.4$ & $49.0 \pm 0.3$ \\
\hline \multicolumn{7}{|c|}{ Hematocrit (mL/dL) } \\
\hline Day 3 & $45.2 \pm 0.5$ & $44.5 \pm 0.7$ & $44.1 \pm 0.6$ & $43.6 \pm 0.4$ & $45.0 \pm 0.6$ & $45.9 \pm 0.4$ \\
\hline Day 23 & $46.2 \pm 0.4$ & $46.8 \pm 0.4$ & $46.4 \pm 0.5$ & $46.6 \pm 0.2$ & $47.0 \pm 0.5$ & $47.4 \pm 0.5$ \\
\hline Week 14 & $48.8 \pm 0.5$ & $47.4 \pm 0.3$ & $48.7 \pm 0.3$ & $49.0 \pm 0.4$ & $48.6 \pm 0.4$ & $48.7 \pm 0.3$ \\
\hline \multicolumn{7}{|c|}{ Hemoglobin (g/dL) } \\
\hline Day 3 & $14.1 \pm 0.2$ & $14.0 \pm 0.2$ & $13.9 \pm 0.2$ & $13.7 \pm 0.2$ & $14.3 \pm 0.2$ & $14.8 \pm 0.2$ \\
\hline Day 23 & $15.1 \pm 0.1$ & $15.3 \pm 0.1$ & $15.3 \pm 0.2$ & $15.1 \pm 0.1$ & $15.4 \pm 0.2$ & $15.4 \pm 0.1$ \\
\hline Week 14 & $15.8 \pm 0.1$ & $15.5 \pm 0.1$ & $15.8 \pm 0.1$ & $16.0 \pm 0.1$ & $15.8 \pm 0.1$ & $15.9 \pm 0.1$ \\
\hline \multicolumn{7}{|c|}{ Erythrocytes $\left(10^{6} / \mu \mathrm{L}\right)$} \\
\hline Day 3 & $7.23 \pm 0.10$ & $7.14 \pm 0.14$ & $7.06 \pm 0.14$ & $7.04 \pm 0.08$ & $7.32 \pm 0.11$ & $7.65 \pm 0.11$ \\
\hline Day 23 & $7.90 \pm 0.06$ & $7.98 \pm 0.10$ & $7.89 \pm 0.14$ & $7.93 \pm 0.07$ & $8.13 \pm 0.11$ & $8.20 \pm 0.09$ \\
\hline Week 14 & $9.24 \pm 0.08$ & $9.03 \pm 0.06$ & $9.19 \pm 0.06$ & $9.30 \pm 0.07$ & $9.19 \pm 0.07$ & $9.09 \pm 0.11$ \\
\hline \multicolumn{7}{|c|}{ Reticulocytes $\left(10^{3} / \mu \mathrm{L}\right)$} \\
\hline Day 3 & $343.5 \pm 15.4$ & $327.3 \pm 27.4$ & $305.9 \pm 19.8$ & $340.4 \pm 13.1$ & $281.7 \pm 20.1$ & $284.2 \pm 19.8$ \\
\hline Day 23 & $240.5 \pm 9.4$ & $223.4 \pm 19.0$ & $203.9 \pm 10.0$ & $207.2 \pm 15.5$ & $221.9 \pm 15.8$ & $263.5 \pm 9.3$ \\
\hline Week 14 & $203.2 \pm 10.8$ & $220.4 \pm 11.5$ & $201.1 \pm 10.4$ & $237.5 \pm 12.2$ & $211.1 \pm 14.8$ & $195.3 \pm 12.7$ \\
\hline \multicolumn{7}{|c|}{ Nucleated erythrocytes/100 leukocytes } \\
\hline Day 3 & $1.50 \pm 0.52$ & $1.40 \pm 0.34$ & $1.60 \pm 0.64$ & $1.00 \pm 0.39$ & $0.90 \pm 0.23$ & $0.40 \pm 0.22$ \\
\hline Day 23 & $0.10 \pm 0.10$ & $0.10 \pm 0.10$ & $0.30 \pm 0.15$ & $0.20 \pm 0.13$ & $0.33 \pm 0.17$ & $0.30 \pm 0.15$ \\
\hline Week 14 & $0.11 \pm 0.11$ & $0.00 \pm 0.00$ & $0.33 \pm 0.24$ & $0.00 \pm 0.00$ & $0.20 \pm 0.13$ & $0.00 \pm 0.00$ \\
\hline \multicolumn{7}{|c|}{ Mean cell volume (fL) } \\
\hline Day 3 & $62.5 \pm 0.3$ & $62.4 \pm 0.4$ & $62.6 \pm 0.6$ & $61.9 \pm 0.4$ & $61.4 \pm 0.4$ & $60.0 \pm 0.5^{* *}$ \\
\hline Day 23 & $58.5 \pm 0.3$ & $58.7 \pm 0.4$ & $58.9 \pm 0.5$ & $58.8 \pm 0.3$ & $57.7 \pm 0.4$ & $57.8 \pm 0.4$ \\
\hline Week 14 & $52.8 \pm 0.1$ & $52.5 \pm 0.2$ & $53.0 \pm 0.2$ & $52.7 \pm 0.1$ & $52.8 \pm 0.2$ & $53.0 \pm 0.2$ \\
\hline
\end{tabular}




\begin{tabular}{|c|c|c|c|c|c|c|}
\hline & $\begin{array}{l}\text { Chamber } \\
\text { Control }\end{array}$ & 12.5 ppm & 25 ppm & $50 \mathrm{ppm}$ & 100 ppm & 200 ppm \\
\hline \multicolumn{7}{|c|}{ Mean cell hemoglobin (pg) } \\
\hline Day 3 & $19.5 \pm 0.1$ & $19.7 \pm 0.1$ & $19.7 \pm 0.1$ & $19.5 \pm 0.1$ & $19.6 \pm 0.1$ & $19.4 \pm 0.1$ \\
\hline Day 23 & $19.1 \pm 0.0$ & $19.2 \pm 0.1$ & $19.3 \pm 0.1$ & $19.1 \pm 0.1$ & $18.9 \pm 0.1$ & $18.7 \pm 0.1^{*}$ \\
\hline Week 14 & $17.1 \pm 0.0$ & $17.2 \pm 0.1$ & $17.2 \pm 0.1$ & $17.1 \pm 0.0$ & $17.2 \pm 0.1$ & $17.3 \pm 0.1$ \\
\hline \multicolumn{7}{|c|}{ Mean cell hemoglobin concentration $(\mathrm{g} / \mathrm{dL})$} \\
\hline Day 3 & $31.2 \pm 0.3$ & $31.5 \pm 0.2$ & $31.4 \pm 0.2$ & $31.5 \pm 0.2$ & $31.8 \pm 0.1$ & $32.3 \pm 0.2^{* *}$ \\
\hline Day 23 & $32.6 \pm 0.1$ & $32.7 \pm 0.2$ & $32.8 \pm 0.2$ & $32.5 \pm 0.1$ & $32.7 \pm 0.1$ & $32.4 \pm 0.2$ \\
\hline Week 14 & $32.4 \pm 0.1$ & $32.8 \pm 0.1$ & $32.5 \pm 0.1$ & $32.5 \pm 0.1$ & $32.5 \pm 0.2$ & $32.6 \pm 0.1$ \\
\hline \multicolumn{7}{|c|}{ Platelets $\left(10^{3} / \mu \mathrm{L}\right)$} \\
\hline Day 3 & $859.9 \pm 19.2$ & $846.8 \pm 13.4$ & $864.2 \pm 21.0$ & $851.7 \pm 13.1$ & $824.6 \pm 20.6$ & $862.2 \pm 24.5$ \\
\hline Day 23 & $804.0 \pm 17.5$ & $746.6 \pm 24.0$ & $766.0 \pm 18.5$ & $784.7 \pm 15.0$ & $761.2 \pm 19.8$ & $791.5 \pm 13.5$ \\
\hline Week 14 & $656.7 \pm 21.1$ & $666.5 \pm 12.6$ & $660.8 \pm 6.6$ & $676.6 \pm 10.0$ & $653.6 \pm 14.3$ & $614.3 \pm 13.1$ \\
\hline \multicolumn{7}{|c|}{ Leukocytes $\left(10^{3} / \mu \mathrm{L}\right)$} \\
\hline Day 3 & $12.20 \pm 0.71$ & $11.68 \pm 0.62$ & $9.82 \pm 0.46^{* *}$ & $9.39 \pm 0.60 * *$ & $8.35 \pm 0.33^{* *}$ & $9.33 \pm 0.39 * *$ \\
\hline Day 23 & $7.84 \pm 0.34$ & $8.68 \pm 0.61$ & $8.65 \pm 0.37$ & $7.46 \pm 0.32$ & $7.66 \pm 0.65$ & $6.86 \pm 0.22$ \\
\hline Week 14 & $8.08 \pm 0.51$ & $8.14 \pm 0.28$ & $8.33 \pm 0.43$ & $8.44 \pm 0.63$ & $9.44 \pm 0.54$ & $7.82 \pm 0.30$ \\
\hline \multicolumn{7}{|c|}{ Segmented neutrophils $\left(10^{3} / \mu \mathrm{L}\right)$} \\
\hline Day 3 & $1.14 \pm 0.07$ & $1.09 \pm 0.09$ & $0.93 \pm 0.03$ & $0.87 \pm 0.05^{*}$ & $0.81 \pm 0.06^{* *}$ & $1.07 \pm 0.08$ \\
\hline Day 23 & $1.10 \pm 0.05$ & $1.04 \pm 0.03$ & $0.96 \pm 0.04$ & $1.04 \pm 0.05$ & $1.09 \pm 0.06$ & $1.19 \pm 0.09$ \\
\hline Week 14 & $1.46 \pm 0.08$ & $1.49 \pm 0.09$ & $1.44 \pm 0.04$ & $1.51 \pm 0.09$ & $1.51 \pm 0.12$ & $1.35 \pm 0.07$ \\
\hline \multicolumn{7}{|c|}{ Lymphocytes $\left(10^{3} / \mu \mathrm{L}\right)$} \\
\hline Day 3 & $10.73 \pm 0.65$ & $10.36 \pm 0.56$ & $8.60 \pm 0.45^{* *}$ & $8.19 \pm 0.56^{* *}$ & $7.32 \pm 0.32 * *$ & $8.08 \pm 0.35^{* *}$ \\
\hline Day 23 & $6.59 \pm 0.31$ & $7.44 \pm 0.61$ & $7.48 \pm 0.37$ & $6.27 \pm 0.31$ & $6.38 \pm 0.67$ & $5.43 \pm 0.21^{*}$ \\
\hline Week 14 & $6.47 \pm 0.50$ & $6.45 \pm 0.26$ & $6.75 \pm 0.45$ & $6.74 \pm 0.59$ & $7.78 \pm 0.49$ & $6.31 \pm 0.29$ \\
\hline \multicolumn{7}{|c|}{ Monocytes $\left(10^{3} / \mu \mathrm{L}\right)$} \\
\hline Day 3 & $0.20 \pm 0.06$ & $0.11 \pm 0.02$ & $0.21 \pm 0.04$ & $0.21 \pm 0.05$ & $0.11 \pm 0.03$ & $0.11 \pm 0.03$ \\
\hline Day 23 & $0.07 \pm 0.02$ & $0.11 \pm 0.04$ & $0.12 \pm 0.03$ & $0.07 \pm 0.02$ & $0.09 \pm 0.03$ & $0.18 \pm 0.05$ \\
\hline Week 14 & $0.07 \pm 0.02$ & $0.11 \pm 0.02$ & $0.04 \pm 0.02$ & $0.10 \pm 0.02$ & $0.09 \pm 0.02$ & $0.09 \pm 0.02$ \\
\hline \multicolumn{7}{|c|}{ Basophils $\left(10^{3} / \mu \mathrm{L}\right)$} \\
\hline Day 3 & $0.012 \pm 0.002$ & $0.006 \pm 0.002$ & $0.006 \pm 0.002$ & $0.006 \pm 0.002$ & $0.004 \pm 0.002$ & $0.015 \pm 0.004$ \\
\hline Day 23 & $0.006 \pm 0.002$ & $0.005 \pm 0.002$ & $0.010 \pm 0.003$ & $0.002 \pm 0.001$ & $0.008 \pm 0.003$ & $0.005 \pm 0.002$ \\
\hline Week 14 & $0.000 \pm 0.000$ & $0.003 \pm 0.002$ & $0.000 \pm 0.000$ & $0.001 \pm 0.001$ & $0.000 \pm 0.000$ & $0.001 \pm 0.001$ \\
\hline \multicolumn{7}{|c|}{ Eosinophils $\left(10^{3} / \mu \mathrm{L}\right)$} \\
\hline Day 3 & $0.12 \pm 0.01$ & $0.12 \pm 0.01$ & $0.08 \pm 0.02$ & $0.11 \pm 0.02$ & $0.10 \pm 0.03^{*}$ & $0.06 \pm 0.01 * *$ \\
\hline Day 23 & $0.08 \pm 0.01$ & $0.08 \pm 0.01$ & $0.08 \pm 0.01$ & $0.08 \pm 0.01$ & $0.09 \pm 0.01$ & $0.06 \pm 0.00$ \\
\hline
\end{tabular}


Triethylamine, NTP TOX 78

\begin{tabular}{lcccccc}
\hline & $\begin{array}{c}\text { Chamber } \\
\text { Control }\end{array}$ & $\mathbf{1 2 . 5} \mathbf{~ p p m}$ & $\mathbf{2 5} \mathbf{~ p p m}$ & $\mathbf{5 0} \mathbf{~ p p m}$ & $\mathbf{1 0 0} \mathbf{~ p p m}$ & $\mathbf{2 0 0} \mathbf{~ p p m}$ \\
\hline Week 14 & $0.07 \pm 0.02$ & $0.10 \pm 0.02$ & $0.10 \pm 0.02$ & $0.10 \pm 0.02$ & $0.07 \pm 0.02$ & $0.07 \pm 0.02$ \\
Immature neutrophils $\left(10^{3} / \mu \mathrm{L}\right)$ & & & & & \\
Day 3 & $0.000 \pm 0.000$ & $0.000 \pm 0.000$ & $0.000 \pm 0.000$ & $0.000 \pm 0.000$ & $0.000 \pm 0.000$ & $0.000 \pm 0.000$ \\
Day 23 & $0.000 \pm 0.000$ & $0.000 \pm 0.000$ & $0.000 \pm 0.000$ & $0.000 \pm 0.000$ & $0.000 \pm 0.000$ & $0.000 \pm 0.000$ \\
Week 14 & $0.000 \pm 0.000$ & $0.000 \pm 0.000$ & $0.000 \pm 0.000$ & $0.000 \pm 0.000$ & $0.000 \pm 0.000$ & $0.000 \pm 0.000$ \\
\hline
\end{tabular}

\section{Clinical Chemistry}

n

\begin{tabular}{|c|c|c|c|c|c|c|}
\hline Day 3 & 10 & 10 & 10 & 10 & 10 & 10 \\
\hline Day 23 & 10 & 10 & 10 & 10 & 9 & 10 \\
\hline Week 14 & 10 & 10 & 10 & 10 & 10 & 10 \\
\hline
\end{tabular}

Urea nitrogen (mg/dL)

$\begin{array}{lcccccc}\text { Day 3 } & 10.1 \pm 0.3 & 7.7 \pm 0.4 * * & 8.5 \pm 0.5 & 7.1 \pm 0.3 * * & 8.6 \pm 0.3 & 11.3 \pm 0.6 \\ \text { Day 23 } & 10.5 \pm 0.5 & 10.5 \pm 0.4 & 10.1 \pm 0.5 & 9.5 \pm 0.3 & 9.9 \pm 0.5 & 9.5 \pm 0.5 \\ \text { Week 14 } & 14.9 \pm 0.5 & 14.2 \pm 0.4 & 14.0 \pm 0.4 & 14.8 \pm 0.4 & 13.7 \pm 0.3 & 13.9 \pm 0.5\end{array}$

Creatinine (mg/dL)

$\begin{array}{lllllll}\text { Day 3 } & 0.50 \pm 0.00^{\mathrm{b}} & 0.49 \pm 0.01 & 0.49 \pm 0.02 & 0.48 \pm 0.01 & 0.53 \pm 0.02 & 0.48 \pm 0.01 \\ \text { Day 23 } & 0.57 \pm 0.02 & 0.57 \pm 0.02 & 0.60 \pm 0.00 & 0.60 \pm 0.02 & 0.60 \pm 0.02 & 0.61 \pm 0.01 \\ \text { Week 14 } & 0.61 \pm 0.02 & 0.58 \pm 0.03 & 0.57 \pm 0.03 & 0.58 \pm 0.01 & 0.59 \pm 0.01 & 0.58 \pm 0.01\end{array}$

Total protein $(\mathrm{g} / \mathrm{dL})$

$\begin{array}{lcccccc}\text { Day 3 } & 6.1 \pm 0.1^{\mathrm{b}} & 6.0 \pm 0.1 & 6.0 \pm 0.1 & 5.9 \pm 0.1 & 5.8 \pm 0.1 & 6.1 \pm 0.1 \\ \text { Day 23 } & 6.3 \pm 0.1 & 6.4 \pm 0.1 & 6.2 \pm 0.0 & 6.4 \pm 0.1 & 6.3 \pm 0.1 & 6.2 \pm 0.0 \\ \text { Week } 14 & 7.2 \pm 0.0 & 7.1 \pm 0.1 & 7.2 \pm 0.1 & 7.2 \pm 0.0 & 7.0 \pm 0.1^{*} & 6.7 \pm 0.1^{* *}\end{array}$

Albumin (g/dL)

\begin{tabular}{lcccccc} 
Day 3 & $4.5 \pm 0.0$ & $4.4 \pm 0.1$ & $4.4 \pm 0.1$ & $4.4 \pm 0.0$ & $4.4 \pm 0.0$ & $4.5 \pm 0.0$ \\
Day 23 & $4.5 \pm 0.0$ & $4.5 \pm 0.0$ & $4.4 \pm 0.0$ & $4.4 \pm 0.0$ & $4.4 \pm 0.0$ & $4.4 \pm 0.0$ \\
Week 14 & $4.7 \pm 0.0$ & $4.7 \pm 0.0$ & $4.7 \pm 0.0$ & $4.7 \pm 0.0$ & $4.6 \pm 0.0^{* *}$ & $4.5 \pm 0.0^{* *}$ \\
Globulin (g/dL) & & & & & & \\
Day 3 & $1.6 \pm 0.0^{\mathrm{b}}$ & $1.6 \pm 0.1$ & $1.6 \pm 0.0$ & $1.5 \pm 0.0$ & $1.5 \pm 0.1$ & $1.7 \pm 0.0$ \\
Day 23 & $1.9 \pm 0.0$ & $1.9 \pm 0.0$ & $1.8 \pm 0.0$ & $1.9 \pm 0.0$ & $1.8 \pm 0.0$ & $1.8 \pm 0.0$ \\
Week 14 & $2.5 \pm 0.0$ & $2.5 \pm 0.0$ & $2.5 \pm 0.0$ & $2.6 \pm 0.0$ & $2.5 \pm 0.0$ & $2.2 \pm 0.0^{* *}$ \\
A/G ratio & & & & & & \\
Day 3 & $2.8 \pm 0.1^{\mathrm{b}}$ & $2.8 \pm 0.1$ & $2.8 \pm 0.1$ & $3.0 \pm 0.1$ & $3.4 \pm 0.6$ & $2.7 \pm 0.1$ \\
Day 23 & $2.4 \pm 0.0$ & $2.4 \pm 0.0$ & $2.5 \pm 0.0$ & $2.3 \pm 0.1$ & $2.4 \pm 0.0$ & $2.5 \pm 0.0$ \\
Week 14 & $1.9 \pm 0.0$ & $1.9 \pm 0.0$ & $1.9 \pm 0.0$ & $1.8 \pm 0.0$ & $1.9 \pm 0.0$ & $2.0 \pm 0.0^{*}$ \\
\hline
\end{tabular}


Triethylamine, NTP TOX 78

\begin{tabular}{|c|c|c|c|c|c|c|}
\hline & $\begin{array}{c}\text { Chamber } \\
\text { Control }\end{array}$ & $12.5 \mathrm{ppm}$ & 25 ppm & 50 ppm & 100 ppm & 200 ppm \\
\hline \multicolumn{7}{|c|}{ Alanine aminotransferase (IU/L) } \\
\hline Day 3 & $55 \pm 2$ & $54 \pm 2$ & $55 \pm 3$ & $50 \pm 2$ & $49 \pm 1 *$ & $41 \pm 1 * *$ \\
\hline Day 23 & $41 \pm 1$ & $41 \pm 1$ & $38 \pm 1$ & $40 \pm 1$ & $41 \pm 1$ & $39 \pm 1$ \\
\hline Week 14 & $81 \pm 5$ & $81 \pm 5$ & $77 \pm 3$ & $75 \pm 4$ & $69 \pm 2 *$ & $57 \pm 3 * *$ \\
\hline \multicolumn{7}{|c|}{ Alkaline phosphatase (IU/L) } \\
\hline Day 3 & $678 \pm 11$ & $695 \pm 15$ & $650 \pm 14$ & $638 \pm 11$ & $608 \pm 10 * *$ & $565 \pm 7 * *$ \\
\hline Day 23 & $474 \pm 15$ & $446 \pm 13$ & $424 \pm 17$ & $450 \pm 12$ & $449 \pm 18$ & $475 \pm 9$ \\
\hline Week 14 & $254 \pm 4$ & $237 \pm 5$ & $243 \pm 8$ & $227 \pm 5^{* *}$ & $224 \pm 6 * *$ & $228 \pm 6^{* *}$ \\
\hline \multicolumn{7}{|c|}{ Creatine kinase (IU/L) } \\
\hline Day 3 & $701 \pm 163^{b}$ & $579 \pm 81$ & $486 \pm 33^{b}$ & $401 \pm 35$ & $733 \pm 159$ & $446 \pm 59$ \\
\hline Day 23 & $333 \pm 22$ & $396 \pm 50$ & $369 \pm 35$ & $327 \pm 21$ & $427 \pm 43$ & $367 \pm 38$ \\
\hline Week 14 & $237 \pm 25$ & $267 \pm 22$ & $236 \pm 27$ & $269 \pm 34$ & $324 \pm 89$ & $219 \pm 33$ \\
\hline \multicolumn{7}{|c|}{ Sorbitol dehydrogenase (IU/L) } \\
\hline Day 3 & $14 \pm 1$ & $15 \pm 1$ & $14 \pm 1$ & $15 \pm 1$ & $14 \pm 1$ & $14 \pm 1$ \\
\hline Day 23 & $14 \pm 0$ & $13 \pm 1$ & $13 \pm 1$ & $13 \pm 0$ & $12 \pm 1$ & $12 \pm 1$ \\
\hline Week 14 & $21 \pm 1$ & $20 \pm 1$ & $21 \pm 1$ & $19 \pm 1$ & $18 \pm 1$ & $16 \pm 1 * *$ \\
\hline \multicolumn{7}{|c|}{ Bile salts $(\mu \mathrm{mol} / \mathrm{L})$} \\
\hline Day 3 & $6.2 \pm 0.6$ & $6.7 \pm 1.2$ & $10.1 \pm 2.2$ & $5.8 \pm 0.6$ & $6.8 \pm 1.0$ & $6.3 \pm 0.9$ \\
\hline Day 23 & $4.5 \pm 0.3$ & $4.3 \pm 0.3$ & $4.0 \pm 0.1$ & $4.2 \pm 0.5$ & $3.6 \pm 0.3$ & $4.5 \pm 0.5$ \\
\hline Week 14 & $3.9 \pm 0.3$ & $3.7 \pm 0.3$ & $4.1 \pm 0.8$ & $3.1 \pm 0.1 * *$ & $3.7 \pm 0.7 * *$ & $4.2 \pm 1.1^{*}$ \\
\hline
\end{tabular}

\section{Female}

\section{Hematology}

n

10

10

10

10

10

10

Hematocrit (spun) (\%)

$\begin{array}{lcccccc}\text { Day } 3 & 48.0 \pm 0.4 & 47.7 \pm 0.5 & 47.5 \pm 0.6 & 48.2 \pm 0.3 & 48.3 \pm 0.5 & 49.4 \pm 0.6 \\ \text { Day 23 } & 47.9 \pm 0.3 & 48.6 \pm 0.2 & 48.3 \pm 0.3 & 48.3 \pm 0.3 & 47.8 \pm 0.4 & 49.8 \pm 0.5^{* *} \\ \text { Week 14 } & 47.3 \pm 0.5 & 48.2 \pm 0.4 & 48.0 \pm 0.5 & 47.7 \pm 0.3 & 48.9 \pm 0.6 & 47.9 \pm 0.5\end{array}$

Hematocrit (mL/dL)

\begin{tabular}{lcccccc} 
Day 3 & $47.1 \pm 0.4$ & $46.9 \pm 0.5$ & $46.5 \pm 0.6$ & $46.9 \pm 0.3$ & $47.4 \pm 0.5$ & $48.6 \pm 0.6$ \\
Day 23 & $47.9 \pm 0.3$ & $48.4 \pm 0.2$ & $48.5 \pm 0.4$ & $48.2 \pm 0.3$ & $47.5 \pm 0.3$ & $49.4 \pm 0.4^{*}$ \\
Week 14 & $47.2 \pm 0.4$ & $48.0 \pm 0.4$ & $48.1 \pm 0.5$ & $47.6 \pm 0.3$ & $49.0 \pm 0.5^{*}$ & $48.0 \pm 0.5$ \\
Hemoglobin $(\mathrm{g} / \mathrm{dL})$ & & & & & & \\
Day 3 & $14.8 \pm 0.2$ & $14.8 \pm 0.2$ & $14.7 \pm 0.2$ & $14.8 \pm 0.1$ & $14.9 \pm 0.1$ & $15.3 \pm 0.2$ \\
Day 23 & $15.7 \pm 0.1$ & $16.1 \pm 0.1$ & $15.9 \pm 0.1$ & $15.7 \pm 0.1$ & $15.6 \pm 0.1$ & $16.2 \pm 0.2^{*}$ \\
Week 14 & $15.6 \pm 0.1$ & $15.7 \pm 0.1$ & $15.8 \pm 0.2$ & $15.6 \pm 0.1$ & $16.0 \pm 0.2$ & $15.7 \pm 0.2$ \\
\hline
\end{tabular}




\begin{tabular}{|c|c|c|c|c|c|c|}
\hline & $\begin{array}{l}\text { Chamber } \\
\text { Control }\end{array}$ & 12.5 ppm & 25 ppm & $50 \mathrm{ppm}$ & 100 ppm & 200 ppm \\
\hline \multicolumn{7}{|c|}{ Erythrocytes $\left(10^{6} / \mu \mathrm{L}\right)$} \\
\hline Day 3 & $7.64 \pm 0.11$ & $7.69 \pm 0.09$ & $7.64 \pm 0.11$ & $7.71 \pm 0.07$ & $7.74 \pm 0.09$ & $8.02 \pm 0.13$ \\
\hline Day 23 & $8.04 \pm 0.10$ & $8.33 \pm 0.07$ & $8.17 \pm 0.06$ & $8.23 \pm 0.06$ & $8.07 \pm 0.09$ & $8.56 \pm 0.09 * *$ \\
\hline Week 14 & $8.45 \pm 0.06$ & $8.56 \pm 0.08$ & $8.56 \pm 0.08$ & $8.50 \pm 0.07$ & $8.71 \pm 0.07$ & $8.56 \pm 0.08$ \\
\hline \multicolumn{7}{|c|}{ Reticulocytes $\left(10^{3} / \mu \mathrm{L}\right)$} \\
\hline Day 3 & $300.6 \pm 21.2$ & $287.2 \pm 25.2$ & $251.1 \pm 18.1$ & $261.3 \pm 21.5$ & $254.8 \pm 21.2$ & $271.9 \pm 19.3$ \\
\hline Day 23 & $155.5 \pm 5.9$ & $134.2 \pm 9.1$ & $156.0 \pm 12.2$ & $151.8 \pm 12.6$ & $158.6 \pm 15.1$ & $132.5 \pm 12.0$ \\
\hline Week 14 & $139.7 \pm 12.2$ & $165.6 \pm 11.3$ & $178.6 \pm 16.0$ & $159.8 \pm 8.7$ & $132.6 \pm 8.7$ & $129.4 \pm 6.8$ \\
\hline \multicolumn{7}{|c|}{ Nucleated erythrocytes/100 leukocytes } \\
\hline Day 3 & $0.60 \pm 0.27$ & $0.30 \pm 0.21$ & $0.40 \pm 0.16$ & $0.50 \pm 0.27$ & $0.80 \pm 0.33$ & $0.90 \pm 0.38$ \\
\hline Day 23 & $0.00 \pm 0.00$ & $0.10 \pm 0.10$ & $0.00 \pm 0.00$ & $0.10 \pm 0.10$ & $0.20 \pm 0.13$ & $0.10 \pm 0.10$ \\
\hline Week 14 & $0.80 \pm 0.25$ & $0.90 \pm 0.31$ & $0.80 \pm 0.25$ & $0.40 \pm 0.16$ & $0.50 \pm 0.17$ & $0.50 \pm 0.22$ \\
\hline \multicolumn{7}{|c|}{ Mean cell volume (fL) } \\
\hline Day 3 & $61.7 \pm 0.4$ & $61.1 \pm 0.3$ & $60.9 \pm 0.5$ & $60.9 \pm 0.4$ & $61.2 \pm 0.3$ & $60.6 \pm 0.5$ \\
\hline Day 23 & $59.6 \pm 0.5$ & $58.1 \pm 0.3$ & $59.4 \pm 0.4$ & $58.6 \pm 0.3$ & $58.9 \pm 0.4$ & $57.8 \pm 0.4^{*}$ \\
\hline Week 14 & $55.9 \pm 0.2$ & $56.1 \pm 0.3$ & $56.2 \pm 0.2$ & $56.1 \pm 0.2$ & $56.3 \pm 0.2$ & $56.1 \pm 0.3$ \\
\hline \multicolumn{7}{|c|}{ Mean cell hemoglobin (pg) } \\
\hline Day 3 & $19.4 \pm 0.1$ & $19.2 \pm 0.1$ & $19.3 \pm 0.1$ & $19.3 \pm 0.1$ & $19.3 \pm 0.1$ & $19.1 \pm 0.1$ \\
\hline Day 23 & $19.5 \pm 0.1$ & $19.3 \pm 0.1$ & $19.4 \pm 0.1$ & $19.1 \pm 0.1$ & $19.4 \pm 0.1$ & $19.0 \pm 0.1 * *$ \\
\hline Week 14 & $18.4 \pm 0.0$ & $18.4 \pm 0.1$ & $18.4 \pm 0.1$ & $18.4 \pm 0.1$ & $18.4 \pm 0.1$ & $18.4 \pm 0.1$ \\
\hline \multicolumn{7}{|c|}{ Mean cell hemoglobin concentration (g/dL) } \\
\hline Day 3 & $31.5 \pm 0.2$ & $31.5 \pm 0.2$ & $31.6 \pm 0.2$ & $31.6 \pm 0.2$ & $31.6 \pm 0.1$ & $31.6 \pm 0.3$ \\
\hline Day 23 & $32.7 \pm 0.1$ & $33.2 \pm 0.1$ & $32.7 \pm 0.2$ & $32.6 \pm 0.2$ & $32.9 \pm 0.1$ & $32.8 \pm 0.3$ \\
\hline Week 14 & $32.9 \pm 0.1$ & $32.8 \pm 0.1$ & $32.8 \pm 0.2$ & $32.8 \pm 0.2$ & $32.6 \pm 0.1$ & $32.8 \pm 0.2$ \\
\hline \multicolumn{7}{|c|}{ Platelets $\left(10^{3} / \mu \mathrm{L}\right)$} \\
\hline Day 3 & $825.2 \pm 21.6$ & $807.4 \pm 38.4$ & $829.1 \pm 23.7$ & $845.2 \pm 17.5$ & $882.2 \pm 31.2$ & $884.6 \pm 40.1$ \\
\hline Day 23 & $810.1 \pm 28.1$ & $709.3 \pm 34.9$ & $810.9 \pm 30.9$ & $770.9 \pm 23.6$ & $806.2 \pm 14.2$ & $778.4 \pm 18.5$ \\
\hline Week 14 & $682.1 \pm 17.2$ & $653.8 \pm 13.9$ & $655.2 \pm 16.7$ & $675.0 \pm 16.8$ & $663.6 \pm 10.9$ & $660.2 \pm 13.5$ \\
\hline \multicolumn{7}{|c|}{ Leukocytes $\left(10^{3} / \mu \mathrm{L}\right)$} \\
\hline Day 3 & $12.66 \pm 0.55$ & $11.83 \pm 0.65$ & $12.15 \pm 0.30$ & $10.68 \pm 0.53^{*}$ & $7.83 \pm 0.29 * *$ & $6.38 \pm 0.45^{* *}$ \\
\hline Day 23 & $8.57 \pm 0.38$ & $7.73 \pm 0.45$ & $7.86 \pm 0.48$ & $7.84 \pm 0.80$ & $7.58 \pm 0.58$ & $6.33 \pm 0.33 * *$ \\
\hline Week 14 & $6.32 \pm 0.46$ & $6.34 \pm 0.23$ & $7.58 \pm 0.40$ & $6.33 \pm 0.30$ & $7.04 \pm 0.42$ & $7.34 \pm 0.32$ \\
\hline \multicolumn{7}{|c|}{ Segmented neutrophils $\left(10^{3} / \mu \mathrm{L}\right)$} \\
\hline Day 3 & $1.06 \pm 0.05$ & $0.82 \pm 0.04 *$ & $0.90 \pm 0.06^{*}$ & $0.75 \pm 0.03 * *$ & $0.66 \pm 0.05^{* *}$ & $0.65 \pm 0.03 * *$ \\
\hline Day 23 & $1.01 \pm 0.10$ & $0.94 \pm 0.10$ & $0.81 \pm 0.07$ & $0.89 \pm 0.11$ & $0.99 \pm 0.10$ & $0.93 \pm 0.13$ \\
\hline
\end{tabular}


Triethylamine, NTP TOX 78

\begin{tabular}{|c|c|c|c|c|c|c|}
\hline & $\begin{array}{l}\text { Chamber } \\
\text { Control }\end{array}$ & 12.5 ppm & 25 ppm & 50 ppm & 100 ppm & 200 ppm \\
\hline Week 14 & $1.08 \pm 0.08$ & $1.20 \pm 0.09$ & $1.47 \pm 0.15$ & $1.26 \pm 0.10$ & $1.35 \pm 0.08$ & $1.31 \pm 0.05$ \\
\hline \multicolumn{7}{|c|}{ Lymphocytes $\left(10^{3} / \mu \mathrm{L}\right)$} \\
\hline Day 3 & $11.22 \pm 0.50$ & $10.65 \pm 0.60$ & $10.88 \pm 0.28$ & $9.60 \pm 0.54 *$ & $6.83 \pm 0.26^{* *}$ & $5.55 \pm 0.43^{* *}$ \\
\hline Day 23 & $7.33 \pm 0.34$ & $6.54 \pm 0.41$ & $6.80 \pm 0.42$ & $6.76 \pm 0.67$ & $6.39 \pm 0.50$ & $5.19 \pm 0.34 * *$ \\
\hline Week 14 & $5.06 \pm 0.45$ & $4.96 \pm 0.16$ & $5.85 \pm 0.34$ & $4.86 \pm 0.24$ & $5.51 \pm 0.42$ & $5.84 \pm 0.29$ \\
\hline \multicolumn{7}{|c|}{ Monocytes $\left(10^{3} / \mu \mathrm{L}\right)$} \\
\hline Day 3 & $0.24 \pm 0.06$ & $0.23 \pm 0.07$ & $0.22 \pm 0.05$ & $0.19 \pm 0.05$ & $0.26 \pm 0.04$ & $0.11 \pm 0.02$ \\
\hline Day 23 & $0.12 \pm 0.03$ & $0.15 \pm 0.03$ & $0.14 \pm 0.04$ & $0.10 \pm 0.04$ & $0.09 \pm 0.04$ & $0.14 \pm 0.04$ \\
\hline Week 14 & $0.09 \pm 0.01$ & $0.08 \pm 0.02$ & $0.16 \pm 0.05$ & $0.12 \pm 0.03$ & $0.09 \pm 0.02$ & $0.07 \pm 0.02$ \\
\hline \multicolumn{7}{|c|}{ Basophils $\left(10^{3} / \mu \mathrm{L}\right)$} \\
\hline Day 3 & $0.012 \pm 0.003$ & $0.015 \pm 0.004$ & $0.012 \pm 0.002$ & $0.008 \pm 0.002$ & $0.008 \pm 0.002$ & $0.004 \pm 0.002 *$ \\
\hline Day 23 & $0.007 \pm 0.002$ & $0.008 \pm 0.002$ & $0.003 \pm 0.002$ & $0.005 \pm 0.002$ & $0.002 \pm 0.001 *$ & $0.000 \pm 0.000 * *$ \\
\hline Week 14 & $0.002 \pm 0.001$ & $0.008 \pm 0.007$ & $0.010 \pm 0.006$ & $0.000 \pm 0.000$ & $0.013 \pm 0.009$ & $0.002 \pm 0.001$ \\
\hline \multicolumn{7}{|c|}{ Eosinophils $\left(10^{3} / \mu \mathrm{L}\right)$} \\
\hline Day 3 & $0.14 \pm 0.01$ & $0.13 \pm 0.01$ & $0.14 \pm 0.02$ & $0.13 \pm 0.02$ & $0.07 \pm 0.00^{* *}$ & $0.07 \pm 0.01 * *$ \\
\hline Day 23 & $0.11 \pm 0.01$ & $0.10 \pm 0.01$ & $0.11 \pm 0.01$ & $0.09 \pm 0.02$ & $0.10 \pm 0.02$ & $0.07 \pm 0.01$ \\
\hline Week 14 & $0.08 \pm 0.02$ & $0.09 \pm 0.02$ & $0.10 \pm 0.01$ & $0.10 \pm 0.01$ & $0.08 \pm 0.02$ & $0.12 \pm 0.01$ \\
\hline \multicolumn{7}{|c|}{ Immature neutrophils $\left(10^{3} / \mu \mathrm{L}\right)$} \\
\hline Day 3 & $0.000 \pm 0.000$ & $0.000 \pm 0.000$ & $0.000 \pm 0.000$ & $0.000 \pm 0.000$ & $0.000 \pm 0.000$ & $0.000 \pm 0.000$ \\
\hline Day 23 & $0.000 \pm 0.000$ & $0.000 \pm 0.000$ & $0.000 \pm 0.000$ & $0.000 \pm 0.000$ & $0.000 \pm 0.000$ & $0.000 \pm 0.000$ \\
\hline Week 14 & $0.000 \pm 0.000$ & $0.000 \pm 0.000$ & $0.000 \pm 0.000$ & $0.000 \pm 0.000$ & $0.000 \pm 0.000$ & $0.000 \pm 0.000$ \\
\hline
\end{tabular}

\section{Clinical Chemistry}

\begin{tabular}{|c|c|c|c|c|c|c|}
\hline $\mathbf{n}$ & 10 & 10 & 10 & 10 & 10 & 10 \\
\hline \multicolumn{7}{|c|}{ Urea nitrogen $(\mathrm{mg} / \mathrm{dL})$} \\
\hline Day 3 & $10.4 \pm 0.5$ & $9.0 \pm 0.3$ & $8.8 \pm 0.5$ & $10.4 \pm 0.5$ & $11.0 \pm 0.4$ & $12.7 \pm 0.5^{*}$ \\
\hline Day 23 & $11.6 \pm 0.4$ & $11.4 \pm 0.3$ & $11.5 \pm 0.3$ & $11.5 \pm 0.5$ & $11.5 \pm 0.4$ & $13.2 \pm 0.6$ \\
\hline Week 14 & $15.4 \pm 0.4$ & $15.5 \pm 0.7$ & $15.2 \pm 0.3$ & $15.1 \pm 0.4$ & $15.5 \pm 0.6$ & $13.2 \pm 0.4 * *$ \\
\hline \multicolumn{7}{|c|}{ Creatinine (mg/dL) } \\
\hline Day 3 & $0.53 \pm 0.02$ & $0.50 \pm 0.00$ & $0.52 \pm 0.01$ & $0.54 \pm 0.02$ & $0.55 \pm 0.02$ & $0.52 \pm 0.01$ \\
\hline Day 23 & $0.61 \pm 0.01$ & $0.62 \pm 0.02$ & $0.65 \pm 0.02$ & $0.61 \pm 0.01$ & $0.62 \pm 0.01$ & $0.65 \pm 0.02$ \\
\hline Week 14 & $0.63 \pm 0.02$ & $0.67 \pm 0.02$ & $0.64 \pm 0.02$ & $0.62 \pm 0.01$ & $0.64 \pm 0.02$ & $0.65 \pm 0.02$ \\
\hline \multicolumn{7}{|c|}{ Total protein $(\mathrm{g} / \mathrm{dL})$} \\
\hline Day 3 & $6.0 \pm 0.1$ & $6.0 \pm 0.1$ & $6.0 \pm 0.1$ & $6.1 \pm 0.1$ & $6.1 \pm 0.1$ & $6.3 \pm 0.0^{*}$ \\
\hline Day 23 & $6.3 \pm 0.1$ & $6.2 \pm 0.0$ & $6.4 \pm 0.1$ & $6.4 \pm 0.1$ & $6.4 \pm 0.1$ & $6.3 \pm 0.1$ \\
\hline Week 14 & $7.3 \pm 0.1$ & $7.4 \pm 0.1$ & $7.3 \pm 0.1$ & $7.1 \pm 0.1$ & $7.2 \pm 0.1$ & $6.5 \pm 0.0 * *$ \\
\hline
\end{tabular}


Triethylamine, NTP TOX 78

\begin{tabular}{|c|c|c|c|c|c|c|}
\hline & $\begin{array}{c}\text { Chamber } \\
\text { Control }\end{array}$ & $12.5 \mathrm{ppm}$ & 25 ppm & 50 ppm & 100 ppm & 200 ppm \\
\hline \multicolumn{7}{|c|}{ Albumin (g/dL) } \\
\hline Day 3 & $4.5 \pm 0.1$ & $4.5 \pm 0.0$ & $4.5 \pm 0.0$ & $4.5 \pm 0.0$ & $4.6 \pm 0.0$ & $4.6 \pm 0.0$ \\
\hline Day 23 & $4.5 \pm 0.0$ & $4.5 \pm 0.0$ & $4.6 \pm 0.0$ & $4.6 \pm 0.1$ & $4.6 \pm 0.0$ & $4.4 \pm 0.0$ \\
\hline Week 14 & $5.1 \pm 0.0$ & $5.1 \pm 0.0$ & $5.1 \pm 0.0$ & $5.0 \pm 0.1$ & $5.1 \pm 0.1$ & $4.6 \pm 0.0^{* *}$ \\
\hline \multicolumn{7}{|c|}{ Globulin (g/dL) } \\
\hline Day 3 & $1.5 \pm 0.0$ & $1.5 \pm 0.0$ & $1.5 \pm 0.0$ & $1.5 \pm 0.0$ & $1.5 \pm 0.0$ & $1.6 \pm 0.0$ \\
\hline Day 23 & $1.8 \pm 0.0$ & $1.7 \pm 0.0$ & $1.8 \pm 0.0$ & $1.8 \pm 0.1$ & $1.8 \pm 0.0$ & $1.8 \pm 0.1$ \\
\hline Week 14 & $2.2 \pm 0.0$ & $2.3 \pm 0.0$ & $2.2 \pm 0.0$ & $2.2 \pm 0.1$ & $2.2 \pm 0.1$ & $1.9 \pm 0.0 * *$ \\
\hline \multicolumn{7}{|l|}{$\mathrm{A} / \mathrm{G}$ ratio } \\
\hline Day 3 & $3.0 \pm 0.1$ & $3.0 \pm 0.1$ & $2.9 \pm 0.1$ & $3.0 \pm 0.1$ & $3.0 \pm 0.0$ & $2.9 \pm 0.1$ \\
\hline Day 23 & $2.6 \pm 0.0$ & $2.6 \pm 0.0$ & $2.5 \pm 0.0$ & $2.5 \pm 0.1$ & $2.5 \pm 0.0$ & $2.4 \pm 0.1$ \\
\hline Week 14 & $2.3 \pm 0.0$ & $2.2 \pm 0.0$ & $2.3 \pm 0.0$ & $2.3 \pm 0.0$ & $2.3 \pm 0.0$ & $2.4 \pm 0.0$ \\
\hline \multicolumn{7}{|c|}{ Alanine aminotransferase (IU/L) } \\
\hline Day 3 & $50 \pm 2$ & $45 \pm 2$ & $47 \pm 1$ & $46 \pm 1$ & $42 \pm 1 * *$ & $42 \pm 1 * *$ \\
\hline Day 23 & $35 \pm 1$ & $36 \pm 1$ & $38 \pm 2$ & $38 \pm 1$ & $36 \pm 1$ & $38 \pm 2$ \\
\hline Week 14 & $52 \pm 2$ & $64 \pm 5$ & $63 \pm 7$ & $58 \pm 4$ & $58 \pm 6$ & $46 \pm 2$ \\
\hline \multicolumn{7}{|c|}{ Alkaline phosphatase (IU/L) } \\
\hline Day 3 & $566 \pm 15$ & $521 \pm 11$ & $532 \pm 12$ & $536 \pm 13$ & $501 \pm 10 * *$ & $480 \pm 13^{* *}$ \\
\hline Day 23 & $334 \pm 6$ & $316 \pm 7$ & $327 \pm 9$ & $327 \pm 6$ & $315 \pm 8$ & $340 \pm 10$ \\
\hline Week 14 & $211 \pm 6$ & $206 \pm 8$ & $198 \pm 9$ & $197 \pm 6$ & $191 \pm 8$ & $198 \pm 9$ \\
\hline \multicolumn{7}{|c|}{ Creatine kinase (IU/L) } \\
\hline Day 3 & $380 \pm 21$ & $384 \pm 26$ & $496 \pm 40$ & $593 \pm 121$ & $452 \pm 32$ & $469 \pm 55$ \\
\hline Day 23 & $294 \pm 25$ & $400 \pm 68$ & $310 \pm 26^{b}$ & $344 \pm 42$ & $421 \pm 66$ & $353 \pm 41$ \\
\hline Week 14 & $277 \pm 20$ & $305 \pm 58$ & $377 \pm 80$ & $606 \pm 121$ & $385 \pm 98$ & $436 \pm 132$ \\
\hline \multicolumn{7}{|c|}{ Sorbitol dehydrogenase (IU/L) } \\
\hline Day 3 & $16 \pm 1$ & $15 \pm 1$ & $17 \pm 1$ & $15 \pm 1$ & $15 \pm 1$ & $14 \pm 1$ \\
\hline Day 23 & $14 \pm 1$ & $13 \pm 1$ & $14 \pm 1$ & $13 \pm 0$ & $14 \pm 1$ & $17 \pm 1$ \\
\hline Week 14 & $16 \pm 1$ & $17 \pm 1$ & $15 \pm 1$ & $16 \pm 1$ & $17 \pm 1$ & $16 \pm 1$ \\
\hline \multicolumn{7}{|c|}{ Bile salts $(\mu \mathrm{mol} / \mathrm{L})$} \\
\hline Day 3 & $7.0 \pm 1.4$ & $7.2 \pm 1.1$ & $7.5 \pm 1.5$ & $7.2 \pm 0.9$ & $7.2 \pm 0.6$ & $5.4 \pm 0.4$ \\
\hline Day 23 & $6.8 \pm 0.9$ & $5.9 \pm 0.7$ & $7.4 \pm 1.5$ & $5.3 \pm 0.4$ & $5.2 \pm 0.6$ & $5.7 \pm 0.6$ \\
\hline Week 14 & $5.0 \pm 0.2$ & $7.7 \pm 1.7$ & $9.9 \pm 2.3$ & $6.9 \pm 0.6$ & $7.0 \pm 1.9$ & $8.5 \pm 1.5$ \\
\hline
\end{tabular}

*Significantly different $(\mathrm{P} \leq 0.05)$ from the chamber control group by Dunn's or Shirley's test. $* * \mathrm{P} \leq 0.01$.

a Data are presented as mean \pm standard error. Statistical tests were performed on unrounded data. $\mathrm{b}_{\mathrm{n}}=9$. 
Triethylamine, NTP TOX 78

Table C-2. Hematology Data for Mice in the Three-month Inhalation Study of Triethylamine ${ }^{a}$

\begin{tabular}{|c|c|c|c|c|c|c|}
\hline & $\begin{array}{l}\text { Chamber } \\
\text { Control }\end{array}$ & $12.5 \mathrm{ppm}$ & 25 ppm & 50 ppm & 100 ppm & 200 ppm \\
\hline $\mathbf{n}$ & 10 & 10 & 10 & 10 & 10 & 10 \\
\hline \multicolumn{7}{|l|}{ Male } \\
\hline Hematocrit (spun) (\%) & $49.9 \pm 0.3$ & $50.6 \pm 0.5$ & $50.2 \pm 0.5$ & $50.4 \pm 0.4$ & $50.3 \pm 0.3$ & $50.2 \pm 0.4$ \\
\hline Hematocrit (mL/dL) & $50.3 \pm 0.3$ & $51.5 \pm 0.4$ & $50.9 \pm 0.5$ & $50.6 \pm 0.3$ & $50.7 \pm 0.3$ & $50.4 \pm 0.6$ \\
\hline Hemoglobin $(\mathrm{g} / \mathrm{dL})$ & $16.0 \pm 0.1$ & $16.4 \pm 0.1$ & $16.1 \pm 0.1$ & $16.2 \pm 0.1$ & $16.1 \pm 0.1$ & $16.2 \pm 0.1$ \\
\hline Erythrocytes $\left(10^{6} / \mu \mathrm{L}\right)$ & $10.41 \pm 0.08$ & $10.62 \pm 0.08$ & $10.53 \pm 0.09$ & $10.40 \pm 0.11$ & $10.51 \pm 0.06$ & $10.41 \pm 0.13$ \\
\hline Reticulocytes $\left(10^{3} / \mu \mathrm{L}\right)$ & $164.0 \pm 15.1$ & $176.0 \pm 14.4$ & $150.9 \pm 11.9$ & $163.3 \pm 8.8$ & $175.2 \pm 20.0$ & $147.6 \pm 11.9$ \\
\hline $\begin{array}{l}\text { Nucleated erythrocytes } \\
\text { /100 erythrocytes }\end{array}$ & $0.00 \pm 0.00$ & $0.00 \pm 0.00$ & $0.00 \pm 0.00$ & $0.00 \pm 0.00$ & $0.00 \pm 0.00$ & $0.10 \pm 0.10$ \\
\hline Mean cell volume (fL) & $48.4 \pm 0.2$ & $48.5 \pm 0.2$ & $48.3 \pm 0.1$ & $48.6 \pm 0.4$ & $48.2 \pm 0.1$ & $48.5 \pm 0.2$ \\
\hline $\begin{array}{l}\text { Mean cell hemoglobin } \\
(\mathrm{pg})\end{array}$ & $15.3 \pm 0.1$ & $15.4 \pm 0.0$ & $15.3 \pm 0.0$ & $15.6 \pm 0.1$ & $15.3 \pm 0.0$ & $15.6 \pm 0.1$ \\
\hline $\begin{array}{l}\text { Mean cell hemoglobin } \\
\text { concentration }(\mathrm{g} / \mathrm{dL})\end{array}$ & $31.7 \pm 0.1$ & $31.8 \pm 0.1$ & $31.7 \pm 0.1$ & $32.0 \pm 0.2$ & $31.8 \pm 0.1$ & $32.1 \pm 0.3$ \\
\hline Platelets $\left(10^{3} / \mu \mathrm{L}\right)$ & $919.2 \pm 19.5$ & $851.3 \pm 35.7$ & $923.2 \pm 15.7$ & $893.9 \pm 19.9$ & $879.6 \pm 21.1$ & $839.7 \pm 36.5$ \\
\hline Leukocytes $\left(10^{3} / \mu \mathrm{L}\right)$ & $3.94 \pm 0.49$ & $3.16 \pm 0.36$ & $3.81 \pm 0.33$ & $3.87 \pm 0.34$ & $3.61 \pm 0.20$ & $3.94 \pm 0.40$ \\
\hline $\begin{array}{l}\text { Segmented neutrophils } \\
\left(10^{3} / \mu \mathrm{L}\right)\end{array}$ & $0.58 \pm 0.07$ & $0.48 \pm 0.06$ & $0.51 \pm 0.04$ & $0.54 \pm 0.05$ & $0.49 \pm 0.03$ & $0.51 \pm 0.06$ \\
\hline Lymphocytes $\left(10^{3} / \mu \mathrm{L}\right)$ & $3.23 \pm 0.41$ & $2.59 \pm 0.30$ & $3.17 \pm 0.27$ & $3.21 \pm 0.29$ & $3.02 \pm 0.18$ & $3.29 \pm 0.33$ \\
\hline Monocytes $\left(10^{3} / \mu \mathrm{L}\right)$ & $0.03 \pm 0.02$ & $0.02 \pm 0.00$ & $0.04 \pm 0.02$ & $0.02 \pm 0.00$ & $0.02 \pm 0.01$ & $0.05 \pm 0.02$ \\
\hline Basophils $\left(10^{3} / \mu \mathrm{L}\right)$ & $0.016 \pm 0.007$ & $0.009 \pm 0.002$ & $0.018 \pm 0.004$ & $0.012 \pm 0.001$ & $0.016 \pm 0.002$ & $0.014 \pm 0.003$ \\
\hline Eosinophils $\left(10^{3} / \mu \mathrm{L}\right)$ & $0.09 \pm 0.02$ & $0.07 \pm 0.02$ & $0.07 \pm 0.01$ & $0.08 \pm 0.02$ & $0.07 \pm 0.01$ & $0.08 \pm 0.01$ \\
\hline $\begin{array}{l}\text { Howell-Jolly bodies } \\
\text { (\% erythrocytes) }\end{array}$ & $0.13 \pm 0.03$ & $0.05 \pm 0.02$ & $0.10 \pm 0.03$ & $0.16 \pm 0.04$ & $0.12 \pm 0.03$ & $0.13 \pm 0.04$ \\
\hline $\begin{array}{l}\text { Immature neutrophils } \\
\left(10^{3} / \mu \mathrm{L}\right)\end{array}$ & $0.000 \pm 0.000$ & $0.000 \pm 0.000$ & $0.000 \pm 0.000$ & $0.000 \pm 0.000$ & $0.000 \pm 0.000$ & $0.000 \pm 0.000$ \\
\hline \multicolumn{7}{|l|}{ Female } \\
\hline Hematocrit (spun) (\%) & $49.9 \pm 0.4$ & $50.3 \pm 0.3$ & $50.1 \pm 0.4$ & $50.1 \pm 0.4$ & $49.3 \pm 0.4$ & $50.0 \pm 0.4$ \\
\hline Hematocrit (mL/dL) & $50.2 \pm 0.6$ & $51.0 \pm 0.3$ & $50.6 \pm 0.4$ & $50.5 \pm 0.4$ & $49.7 \pm 0.4$ & $50.2 \pm 0.4$ \\
\hline Hemoglobin (g/dL) & $16.1 \pm 0.2$ & $16.4 \pm 0.1$ & $16.2 \pm 0.1$ & $16.2 \pm 0.1$ & $15.9 \pm 0.1$ & $16.1 \pm 0.1$ \\
\hline Erythrocytes $\left(10^{6} / \mu \mathrm{L}\right)$ & $10.25 \pm 0.12$ & $10.41 \pm 0.06$ & $10.21 \pm 0.11$ & $10.26 \pm 0.08$ & $10.06 \pm 0.10$ & $10.22 \pm 0.07$ \\
\hline Reticulocytes $\left(10^{3} / \mu \mathrm{L}\right)$ & $171.4 \pm 18.9$ & $196.8 \pm 18.9$ & $198.3 \pm 19.7$ & $202.8 \pm 16.8$ & $188.1 \pm 10.8$ & $173.9 \pm 17.3$ \\
\hline $\begin{array}{l}\text { Nucleated erythrocytes } \\
\text { /100 erythrocytes }\end{array}$ & $0.00 \pm 0.00$ & $0.00 \pm 0.00$ & $0.00 \pm 0.00$ & $0.00 \pm 0.00$ & $0.00 \pm 0.00$ & $0.00 \pm 0.00$ \\
\hline Mean cell volume (fL) & $49.0 \pm 0.2$ & $49.0 \pm 0.3$ & $49.6 \pm 0.2$ & $49.2 \pm 0.2$ & $49.5 \pm 0.2$ & $49.2 \pm 0.1$ \\
\hline $\begin{array}{l}\text { Mean cell hemoglobin } \\
(\mathrm{pg})\end{array}$ & $15.8 \pm 0.1$ & $15.7 \pm 0.1$ & $15.9 \pm 0.1$ & $15.8 \pm 0.0$ & $15.9 \pm 0.1$ & $15.8 \pm 0.0$ \\
\hline
\end{tabular}


Triethylamine, NTP TOX 78

\begin{tabular}{|c|c|c|c|c|c|c|}
\hline & $\begin{array}{l}\text { Chamber } \\
\text { Control }\end{array}$ & 12.5 ppm & 25 ppm & $50 \mathrm{ppm}$ & 100 ppm & 200 ppm \\
\hline $\begin{array}{l}\text { Mean cell hemoglobin } \\
\text { concentration }(\mathrm{g} / \mathrm{dL})\end{array}$ & $32.2 \pm 0.1$ & $32.0 \pm 0.2$ & $32.0 \pm 0.1$ & $32.1 \pm 0.1$ & $32.1 \pm 0.1$ & $32.1 \pm 0.1$ \\
\hline Platelets $\left(10^{3} / \mu \mathrm{L}\right)$ & $834.6 \pm 19.7$ & $820.3 \pm 14.8$ & $811.7 \pm 17.5$ & $820.2 \pm 8.8$ & $842.3 \pm 19.0$ & $783.9 \pm 23.0$ \\
\hline Leukocytes $\left(10^{3} / \mu \mathrm{L}\right)$ & $3.31 \pm 0.14$ & $3.96 \pm 0.36$ & $3.07 \pm 0.23$ & $3.66 \pm 0.71$ & $3.36 \pm 0.43$ & $3.49 \pm 0.32$ \\
\hline $\begin{array}{l}\text { Segmented neutrophils } \\
\left(10^{3} / \mu \mathrm{L}\right)\end{array}$ & $0.37 \pm 0.04$ & $0.50 \pm 0.07$ & $0.40 \pm 0.05$ & $0.44 \pm 0.08$ & $0.42 \pm 0.06$ & $0.36 \pm 0.03$ \\
\hline Lymphocytes $\left(10^{3} / \mu \mathrm{L}\right)$ & $2.87 \pm 0.14$ & $3.36 \pm 0.30$ & $2.57 \pm 0.19$ & $3.15 \pm 0.65$ & $2.86 \pm 0.38$ & $3.03 \pm 0.29$ \\
\hline Monocytes $\left(10^{3} / \mu \mathrm{L}\right)$ & $0.03 \pm 0.01$ & $0.02 \pm 0.01$ & $0.03 \pm 0.01$ & $0.03 \pm 0.01$ & $0.02 \pm 0.01$ & $0.03 \pm 0.01$ \\
\hline Basophils $\left(10^{3} / \mu \mathrm{L}\right)$ & $0.012 \pm 0.003$ & $0.021 \pm 0.005$ & $0.016 \pm 0.004$ & $0.015 \pm 0.003$ & $0.015 \pm 0.005$ & $0.021 \pm 0.004$ \\
\hline Eosinophils $\left(10^{3} / \mu \mathrm{L}\right)$ & $0.04 \pm 0.00$ & $0.06 \pm 0.01$ & $0.05 \pm 0.01$ & $0.04 \pm 0.01$ & $0.05 \pm 0.01$ & $0.05 \pm 0.01$ \\
\hline $\begin{array}{l}\text { Howell-Jolly bodies } \\
\text { (\% erythrocytes) }\end{array}$ & $0.05 \pm 0.02$ & $0.10 \pm 0.03$ & $0.08 \pm 0.02$ & $0.09 \pm 0.02$ & $0.13 \pm 0.03$ & $0.07 \pm 0.02$ \\
\hline $\begin{array}{l}\text { Immature neutrophils } \\
\left(10^{3} / \mu \mathrm{L}\right)\end{array}$ & $0.000 \pm 0.000$ & $0.000 \pm 0.000$ & $0.000 \pm 0.000$ & $0.000 \pm 0.000$ & $0.000 \pm 0.000$ & $0.000 \pm 0.000$ \\
\hline
\end{tabular}




\section{Appendix D. Organ Weights and Organ-Weight-to-Body- Weight Ratios}

\section{Tables}

Table D-1. Organ Weights and Organ-Weight-to-Body-Weight Ratios for Rats in the Two-week Inhalation Study of Triethylamine .... D-2

Table D-2. Organ Weights and Organ-Weight-to-Body-Weight Ratios for Rats in the Three-month Inhalation Study of Triethylamine

Table D-3. Organ Weights and Organ-Weight-to-Body-Weight Ratios for Mice in the Two-week Inhalation Study of Triethylamine D-6

Table D-4. Organ Weights and Organ-Weight-to-Body-Weight Ratios for Mice in the Three-month Inhalation Study of Triethylamine. D-8 
Triethylamine, NTP TOX 78

Table D-1. Organ Weights and Organ-Weight-to-Body-Weight Ratios for Rats in the Two-week Inhalation Study of Triethylamine ${ }^{a}$

\begin{tabular}{|c|c|c|c|c|c|c|}
\hline & $\begin{array}{l}\text { Chamber } \\
\text { Control }\end{array}$ & 100 ppm & 200 ppm & 400 ppm & 800 ppm & 1,000 ppm \\
\hline $\mathbf{n}$ & 5 & 5 & 5 & 5 & $0^{\mathrm{b}}$ & $0^{\mathrm{b}}$ \\
\hline \multicolumn{7}{|l|}{ Male } \\
\hline Necropsy body wt & $170 \pm 4$ & $159 \pm 4^{*}$ & $152 \pm 3^{* *}$ & $120 \pm 3^{* *}$ & - & - \\
\hline \multicolumn{7}{|l|}{ Heart } \\
\hline Absolute & $0.642 \pm 0.023$ & $0.564 \pm 0.008^{* *}$ & $0.572 \pm 0.019^{*}$ & $0.510 \pm 0.018^{* *}$ & - & - \\
\hline Relative & $3.784 \pm 0.133$ & $3.550 \pm 0.059$ & $3.775 \pm 0.089$ & $4.260 \pm 0.099 * *$ & - & - \\
\hline \multicolumn{7}{|l|}{ R. Kidney } \\
\hline Absolute & $0.682 \pm 0.011$ & $0.640 \pm 0.014$ & $0.654 \pm 0.015$ & $0.542 \pm 0.017 * *$ & - & - \\
\hline Relative & $4.022 \pm 0.081$ & $4.026 \pm 0.061$ & $4.321 \pm 0.106^{*}$ & $4.531 \pm 0.104 * *$ & - & - \\
\hline \multicolumn{7}{|l|}{ Liver } \\
\hline Absolute & $7.750 \pm 0.213$ & $6.986 \pm 0.131 *$ & $6.898 \pm 0.281^{*}$ & $5.414 \pm 0.174 * *$ & - & - \\
\hline Relative & $45.626 \pm 0.268$ & $43.986 \pm 1.011$ & $45.565 \pm 1.817$ & $45.215 \pm 0.460$ & - & - \\
\hline \multicolumn{7}{|l|}{ Lung } \\
\hline Absolute & $1.252 \pm 0.114$ & $1.498 \pm 0.135$ & $1.416 \pm 0.132$ & $1.006 \pm 0.072$ & - & - \\
\hline Relative & $7.346 \pm 0.544$ & $9.414 \pm 0.801$ & $9.324 \pm 0.766$ & $8.403 \pm 0.552$ & - & - \\
\hline \multicolumn{7}{|l|}{ R. Testis } \\
\hline Absolute & $1.090 \pm 0.018$ & $1.049 \pm 0.039$ & $1.019 \pm 0.018$ & $0.630 \pm 0.043^{* *}$ & - & - \\
\hline Relative & $6.427 \pm 0.105$ & $6.591 \pm 0.144$ & $6.730 \pm 0.068$ & $5.252 \pm 0.266^{* *}$ & - & - \\
\hline \multicolumn{7}{|l|}{ Thymus } \\
\hline Absolute & $0.447 \pm 0.023$ & $0.447 \pm 0.012$ & $0.403 \pm 0.018$ & $0.184 \pm 0.012 * *$ & - & - \\
\hline Relative & $2.626 \pm 0.072$ & $2.815 \pm 0.089$ & $2.663 \pm 0.112$ & $1.536 \pm 0.067 * *$ & - & - \\
\hline \multicolumn{7}{|l|}{ Female } \\
\hline Necropsy body wt & $128 \pm 2$ & $125 \pm 2$ & $117 \pm 3^{* *}$ & $103 \pm 3^{* *}$ & - & - \\
\hline \multicolumn{7}{|l|}{ Heart } \\
\hline Absolute & $0.482 \pm 0.004$ & $0.478 \pm 0.023$ & $0.466 \pm 0.006$ & $0.468 \pm 0.007$ & - & - \\
\hline Relative & $3.764 \pm 0.047$ & $3.814 \pm 0.145$ & $3.982 \pm 0.069$ & $4.548 \pm 0.079 * *$ & - & - \\
\hline \multicolumn{7}{|l|}{ R. Kidney } \\
\hline Absolute & $0.516 \pm 0.014$ & $0.570 \pm 0.012 *$ & $0.550 \pm 0.009$ & $0.556 \pm 0.014$ & - & - \\
\hline Relative & $4.029 \pm 0.108$ & $4.555 \pm 0.093^{* *}$ & $4.702 \pm 0.110^{* *}$ & $5.404 \pm 0.153^{* *}$ & - & - \\
\hline \multicolumn{7}{|l|}{ Liver } \\
\hline Absolute & $5.298 \pm 0.083$ & $5.284 \pm 0.199$ & $4.940 \pm 0.104$ & $5.120 \pm 0.093$ & - & - \\
\hline Relative & $41.356 \pm 0.387$ & $42.196 \pm 1.335$ & $42.185 \pm 0.576$ & $49.724 \pm 0.532 * *$ & - & - \\
\hline
\end{tabular}


Triethylamine, NTP TOX 78

\begin{tabular}{lcccccc}
\hline & $\begin{array}{c}\text { Chamber } \\
\text { Control }\end{array}$ & $\mathbf{1 0 0} \mathbf{~ p p m}$ & $\mathbf{2 0 0} \mathbf{~ p p m}$ & $\mathbf{4 0 0} \mathbf{~ p p m}$ & $\mathbf{8 0 0} \mathbf{~ p p m}$ & $\mathbf{1 , 0 0 0} \mathbf{~ p p m}$ \\
\hline Lung & & & & & \\
$\quad$ Absolute & $0.866 \pm 0.059$ & $0.972 \pm 0.048$ & $1.034 \pm 0.081$ & $1.036 \pm 0.109$ & - & - \\
$\quad \begin{array}{l}\text { Relative } \\
\text { Thymus }\end{array}$ & $6.753 \pm 0.414$ & $7.752 \pm 0.295$ & $8.880 \pm 0.843^{*}$ & $9.986 \pm 0.858^{* *}$ & - & - \\
$\quad$ Absolute & $0.381 \pm 0.014$ & $0.388 \pm 0.028$ & $0.351 \pm 0.019$ & $0.174 \pm 0.015^{* *}$ & - & - \\
Relative & $2.972 \pm 0.114$ & $3.093 \pm 0.184$ & $2.990 \pm 0.128$ & $1.684 \pm 0.133^{* *}$ & - & - \\
\hline
\end{tabular}

*Significantly different $(\mathrm{P} \leq 0.05)$ from the chamber control group by Williams' or Dunnett's test.

$* * \mathrm{P} \leq 0.01$.

${ }^{\mathrm{a}}$ Organ weights (absolute weights) and body weights are given in grams; organ-weight-to-body-weight ratios (relative weights) are given as $\mathrm{mg}$ organ weight/g body weight (mean \pm standard error).

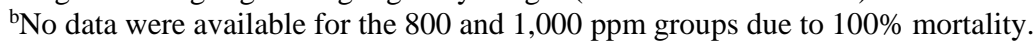


Table D-2. Organ Weights and Organ-Weight-to-Body-Weight Ratios for Rats in the Three-month Inhalation Study of Triethylamine ${ }^{\text {a }}$

\begin{tabular}{|c|c|c|c|c|c|c|}
\hline & $\begin{array}{c}\text { Chamber } \\
\text { Control }\end{array}$ & 12.5 ppm & 25 ppm & $50 \mathrm{ppm}$ & 100 ppm & 200 ppm \\
\hline n & 10 & 10 & 10 & 10 & 10 & 10 \\
\hline \multicolumn{7}{|l|}{ Male } \\
\hline $\begin{array}{l}\text { Necropsy } \\
\text { body wt }\end{array}$ & $347 \pm 7$ & $360 \pm 8$ & $343 \pm 9$ & $352 \pm 8$ & $338 \pm 4$ & $300 \pm 5 * *$ \\
\hline \multicolumn{7}{|l|}{ Heart } \\
\hline Absolute & $0.955 \pm 0.021$ & $0.973 \pm 0.022$ & $0.957 \pm 0.021$ & $0.955 \pm 0.022$ & $0.943 \pm 0.010$ & $0.860 \pm 0.013^{* *}$ \\
\hline Relative & $2.755 \pm 0.027$ & $2.707 \pm 0.029$ & $2.800 \pm 0.046$ & $2.716 \pm 0.033$ & $2.792 \pm 0.022$ & $2.868 \pm 0.024^{*}$ \\
\hline \multicolumn{7}{|l|}{ R. Kidney } \\
\hline Absolute & $1.041 \pm 0.020$ & $1.085 \pm 0.024$ & $1.046 \pm 0.034$ & $1.094 \pm 0.022$ & $1.038 \pm 0.013$ & $0.976 \pm 0.016$ \\
\hline Relative & $3.006 \pm 0.042$ & $3.017 \pm 0.019$ & $3.052 \pm 0.039$ & $3.113 \pm 0.026$ & $3.073 \pm 0.033$ & $3.256 \pm 0.041 * *$ \\
\hline \multicolumn{7}{|l|}{ Liver } \\
\hline Absolute & $11.36 \pm 0.29$ & $12.14 \pm 0.52$ & $11.27 \pm 0.45$ & $11.71 \pm 0.39$ & $11.15 \pm 0.20$ & $10.17 \pm 0.24 *$ \\
\hline Relative & $32.755 \pm 0.263$ & $33.625 \pm 0.754$ & $32.816 \pm 0.469$ & $33.245 \pm 0.545$ & $32.973 \pm 0.348$ & $33.875 \pm 0.426$ \\
\hline \multicolumn{7}{|l|}{ Lung } \\
\hline Absolute & $1.874 \pm 0.094$ & $1.693 \pm 0.056$ & $1.697 \pm 0.089$ & $1.714 \pm 0.081$ & $1.692 \pm 0.038$ & $1.500 \pm 0.049 * *$ \\
\hline Relative & $5.394 \pm 0.223$ & $4.707 \pm 0.113^{* *}$ & $4.934 \pm 0.156$ & $4.857 \pm 0.142$ & $5.009 \pm 0.106$ & $4.993 \pm 0.107$ \\
\hline \multicolumn{7}{|l|}{ R. Testis } \\
\hline Absolute & $1.429 \pm 0.012$ & $1.432 \pm 0.028$ & $1.445 \pm 0.031$ & $1.453 \pm 0.012$ & $1.481 \pm 0.058$ & $1.370 \pm 0.018$ \\
\hline Relative & $4.135 \pm 0.085$ & $3.987 \pm 0.059$ & $4.229 \pm 0.067$ & $4.146 \pm 0.081$ & $4.386 \pm 0.174$ & $4.573 \pm 0.064 * *$ \\
\hline \multicolumn{7}{|l|}{ Thymus } \\
\hline Absolute & $0.325 \pm 0.015$ & $0.298 \pm 0.010$ & $0.319 \pm 0.011$ & $0.304 \pm 0.018$ & $0.318 \pm 0.013$ & $0.257 \pm 0.013^{* *}$ \\
\hline Relative & $0.937 \pm 0.035$ & $0.830 \pm 0.030$ & $0.932 \pm 0.028$ & $0.865 \pm 0.047$ & $0.941 \pm 0.034$ & $0.856 \pm 0.042$ \\
\hline \multicolumn{7}{|l|}{ Female } \\
\hline $\begin{array}{l}\text { Necropsy } \\
\text { body wt }\end{array}$ & $209 \pm 4$ & $211 \pm 4$ & $204 \pm 3$ & $207 \pm 5$ & $198 \pm 5$ & $181 \pm 3^{* *}$ \\
\hline \multicolumn{7}{|l|}{ Heart } \\
\hline Absolute & $0.646 \pm 0.017$ & $0.650 \pm 0.011$ & $0.630 \pm 0.007$ & $0.639 \pm 0.013$ & $0.623 \pm 0.015$ & $0.584 \pm 0.007 * *$ \\
\hline Relative & $3.096 \pm 0.053$ & $3.096 \pm 0.074$ & $3.088 \pm 0.049$ & $3.088 \pm 0.039$ & $3.164 \pm 0.100$ & $3.223 \pm 0.045$ \\
\hline \multicolumn{7}{|l|}{ R. Kidney } \\
\hline Absolute & $0.689 \pm 0.016$ & $0.700 \pm 0.010$ & $0.692 \pm 0.008$ & $0.696 \pm 0.012$ & $0.684 \pm 0.014$ & $0.656 \pm 0.007$ \\
\hline Relative & $3.305 \pm 0.067$ & $3.327 \pm 0.026$ & $3.390 \pm 0.044$ & $3.368 \pm 0.063$ & $3.465 \pm 0.060^{*}$ & $3.620 \pm 0.042 * *$ \\
\hline \multicolumn{7}{|l|}{ Liver } \\
\hline Absolute & $6.460 \pm 0.179$ & $6.664 \pm 0.179$ & $6.464 \pm 0.121$ & $6.441 \pm 0.193$ & $6.245 \pm 0.219$ & $5.768 \pm 0.064 * *$ \\
\hline Relative & $30.940 \pm 0.514$ & $31.638 \pm 0.523$ & $31.657 \pm 0.535$ & $31.078 \pm 0.524$ & $31.529 \pm 0.634$ & $31.849 \pm 0.556$ \\
\hline \multicolumn{7}{|l|}{ Lung } \\
\hline Absolute & $1.160 \pm 0.025$ & $1.218 \pm 0.027$ & $1.168 \pm 0.024$ & $1.251 \pm 0.042$ & $1.212 \pm 0.028$ & $1.132 \pm 0.017$ \\
\hline Relative & $5.560 \pm 0.066$ & $5.790 \pm 0.109$ & $5.732 \pm 0.165$ & $6.042 \pm 0.157 *$ & $6.156 \pm 0.198^{* *}$ & $6.257 \pm 0.157^{* *}$ \\
\hline \multicolumn{7}{|l|}{ Thymus } \\
\hline Absolute & $0.284 \pm 0.015$ & $0.295 \pm 0.016$ & $0.285 \pm 0.010$ & $0.292 \pm 0.008$ & $0.264 \pm 0.012$ & $0.242 \pm 0.011^{*}$ \\
\hline
\end{tabular}


Triethylamine, NTP TOX 78

\begin{tabular}{|c|c|c|c|c|c|c|}
\hline & $\begin{array}{c}\text { Chamber } \\
\text { Control }\end{array}$ & $12.5 \mathrm{ppm}$ & 25 ppm & 50 ppm & 100 ppm & 200 ppm \\
\hline Relative & $1.358 \pm 0.062$ & $1.400 \pm 0.066$ & $1.396 \pm 0.057$ & $1.414 \pm 0.050$ & $1.341 \pm 0.063$ & $1.335 \pm 0.065$ \\
\hline
\end{tabular}


Table D-3. Organ Weights and Organ-Weight-to-Body-Weight Ratios for Mice in the Two-week Inhalation Study of Triethylamine ${ }^{\text {a }}$

\begin{tabular}{|c|c|c|c|c|c|c|}
\hline & $\begin{array}{l}\text { Chamber } \\
\text { Control }\end{array}$ & 100 ppm & $200 \mathrm{ppm}$ & $400 \mathrm{ppm}$ & 800 ppm & 1,000 ppm \\
\hline $\mathbf{n}$ & 5 & 5 & 5 & 5 & $0^{\mathrm{b}}$ & $0^{\mathrm{b}}$ \\
\hline \multicolumn{7}{|l|}{ Male } \\
\hline Necropsy body wt & $26.2 \pm 0.6$ & $25.6 \pm 0.6$ & $24.7 \pm 0.5$ & $19.4 \pm 0.6^{* *}$ & - & - \\
\hline \multicolumn{7}{|l|}{ Heart } \\
\hline Absolute & $0.124 \pm 0.005$ & $0.116 \pm 0.004$ & $0.116 \pm 0.002$ & $0.098 \pm 0.002 * *$ & - & - \\
\hline Relative & $4.724 \pm 0.147$ & $4.534 \pm 0.107$ & $4.696 \pm 0.093$ & $5.068 \pm 0.063$ & - & - \\
\hline \multicolumn{7}{|l|}{ R. Kidney } \\
\hline Absolute & $0.214 \pm 0.002$ & $0.230 \pm 0.010$ & $0.228 \pm 0.007$ & $0.170 \pm 0.008 * *$ & - & - \\
\hline Relative & $8.166 \pm 0.129$ & $8.980 \pm 0.292$ & $9.235 \pm 0.322 *$ & $8.766 \pm 0.193$ & - & - \\
\hline \multicolumn{7}{|l|}{ Liver } \\
\hline Absolute & $1.348 \pm 0.044$ & $1.276 \pm 0.055$ & $1.182 \pm 0.040^{*}$ & $0.930 \pm 0.046^{* *}$ & - & - \\
\hline Relative & $51.364 \pm 1.117$ & $49.800 \pm 1.052$ & $47.764 \pm 0.748$ & $47.916 \pm 1.131$ & - & - \\
\hline \multicolumn{7}{|l|}{ Lung } \\
\hline Absolute & $0.180 \pm 0.007$ & $0.180 \pm 0.010$ & $0.182 \pm 0.006$ & $0.174 \pm 0.010$ & - & - \\
\hline Relative & $6.863 \pm 0.236$ & $7.026 \pm 0.280$ & $7.367 \pm 0.217$ & $8.961 \pm 0.277 * *$ & - & - \\
\hline \multicolumn{7}{|l|}{ R. Testis } \\
\hline Absolute & $0.102 \pm 0.003$ & $0.104 \pm 0.002$ & $0.103 \pm 0.003$ & $0.096 \pm 0.002$ & - & - \\
\hline Relative & $3.873 \pm 0.067$ & $4.072 \pm 0.099$ & $4.189 \pm 0.125^{*}$ & $4.954 \pm 0.065^{* *}$ & - & - \\
\hline \multicolumn{7}{|l|}{ Thymus } \\
\hline Absolute & $0.058 \pm 0.005$ & $0.056 \pm 0.001$ & $0.043 \pm 0.002 * *$ & $0.015 \pm 0.003^{* *}$ & - & - \\
\hline Relative & $2.219 \pm 0.152$ & $2.175 \pm 0.022$ & $1.740 \pm 0.080 * *$ & $0.785 \pm 0.115^{* *}$ & - & - \\
\hline \multicolumn{7}{|l|}{ Female } \\
\hline Necropsy body wt & $22.7 \pm 0.4$ & $22.9 \pm 0.4$ & $21.8 \pm 0.5$ & $17.1 \pm 0.3 * *$ & - & - \\
\hline \multicolumn{7}{|l|}{ Heart } \\
\hline Absolute & $0.116 \pm 0.002$ & $0.128 \pm 0.013$ & $0.110 \pm 0.005$ & $0.086 \pm 0.004 *$ & - & - \\
\hline Relative & $5.102 \pm 0.067$ & $5.582 \pm 0.553$ & $5.031 \pm 0.153$ & $5.021 \pm 0.149$ & - & - \\
\hline \multicolumn{7}{|l|}{ R. Kidney } \\
\hline Absolute & $0.172 \pm 0.007$ & $0.174 \pm 0.007$ & $0.166 \pm 0.007$ & $0.146 \pm 0.002 * *$ & - & - \\
\hline Relative & $7.555 \pm 0.191$ & $7.603 \pm 0.342$ & $7.599 \pm 0.190$ & $8.544 \pm 0.136^{*}$ & - & - \\
\hline \multicolumn{7}{|l|}{ Liver } \\
\hline Absolute & $1.218 \pm 0.041$ & $1.170 \pm 0.020$ & $1.148 \pm 0.044$ & $0.836 \pm 0.015^{* *}$ & - & - \\
\hline Relative & $53.509 \pm 0.951$ & $51.071 \pm 0.773$ & $52.546 \pm 1.013$ & $48.903 \pm 0.465^{* *}$ & - & - \\
\hline
\end{tabular}


Triethylamine, NTP TOX 78

\begin{tabular}{lcccccc}
\hline & $\begin{array}{c}\text { Chamber } \\
\text { Control }\end{array}$ & $\mathbf{1 0 0} \mathbf{~ p p m}$ & $\mathbf{2 0 0} \mathbf{~ p p m}$ & $\mathbf{4 0 0} \mathbf{~ p p m}$ & $\mathbf{8 0 0} \mathbf{~ p p m}$ & $\mathbf{1 , 0 0 0} \mathbf{~ p p m}$ \\
\hline Lung & & & & & \\
$\quad$ Absolute & $0.186 \pm 0.010$ & $0.210 \pm 0.024$ & $0.190 \pm 0.009$ & $0.190 \pm 0.013$ & - & - \\
$\quad \begin{array}{l}\text { Relative } \\
\text { Thymus }\end{array}$ & $8.186 \pm 0.448$ & $9.138 \pm 0.965$ & $8.690 \pm 0.231$ & $11.130 \pm 0.815^{* *}$ & - & - \\
$\quad$ Absolute & $0.081 \pm 0.008$ & $0.075 \pm 0.002$ & $0.065 \pm 0.010$ & $0.017 \pm 0.002^{* *}$ & - & - \\
Relative & $3.563 \pm 0.311$ & $3.256 \pm 0.092$ & $2.954 \pm 0.420$ & $0.966 \pm 0.101 * *$ & - & - \\
\hline
\end{tabular}

*Significantly different $(\mathrm{P} \leq 0.05)$ from the chamber control group by Williams' or Dunnett's test.

$* * \mathrm{P} \leq 0.01$.

${ }^{\mathrm{a}}$ Organ weights (absolute weights) and body weights are given in grams; organ-weight-to-body-weight ratios (relative weights) are given as $\mathrm{mg}$ organ weight/g body weight (mean \pm standard error).

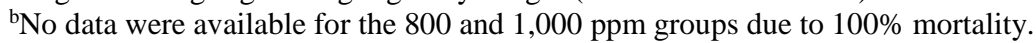


Table D-4. Organ Weights and Organ-Weight-to-Body-Weight Ratios for Mice in the Three-month Inhalation Study of Triethylamine ${ }^{a}$

\begin{tabular}{|c|c|c|c|c|c|c|}
\hline & $\begin{array}{l}\text { Chamber } \\
\text { Control }\end{array}$ & 12.5 ppm & 25 ppm & 50 ppm & 100 ppm & 200 ppm \\
\hline $\mathbf{n}$ & 10 & 10 & 10 & 10 & 10 & 10 \\
\hline \multicolumn{7}{|l|}{ Male } \\
\hline Necropsy body wt & $37.6 \pm 0.8$ & $38.3 \pm 0.9$ & $37.6 \pm 0.7$ & $38.6 \pm 0.5$ & $38.3 \pm 0.6$ & $31.9 \pm 0.6^{* *}$ \\
\hline \multicolumn{7}{|l|}{ Heart } \\
\hline Absolute & $0.162 \pm 0.003$ & $0.169 \pm 0.003$ & $0.161 \pm 0.002$ & $0.169 \pm 0.004$ & $0.162 \pm 0.003$ & $0.145 \pm 0.003 * *$ \\
\hline Relative & $4.314 \pm 0.092$ & $4.421 \pm 0.087$ & $4.299 \pm 0.091$ & $4.386 \pm 0.105$ & $4.238 \pm 0.084$ & $4.550 \pm 0.102$ \\
\hline \multicolumn{7}{|l|}{ R. Kidney } \\
\hline Absolute & $0.309 \pm 0.008$ & $0.310 \pm 0.006$ & $0.315 \pm 0.005$ & $0.327 \pm 0.010$ & $0.315 \pm 0.007$ & $0.278 \pm 0.006 *$ \\
\hline Relative & $8.232 \pm 0.226$ & $8.111 \pm 0.171$ & $8.400 \pm 0.118$ & $8.474 \pm 0.213$ & $8.234 \pm 0.165$ & $8.718 \pm 0.177$ \\
\hline \multicolumn{7}{|l|}{ Liver } \\
\hline Absolute & $1.644 \pm 0.046$ & $1.648 \pm 0.041$ & $1.582 \pm 0.032$ & $1.615 \pm 0.030$ & $1.599 \pm 0.020$ & $1.322 \pm 0.038 * *$ \\
\hline Relative & $43.681 \pm 0.759$ & $43.040 \pm 0.671$ & $42.199 \pm 0.848$ & $41.865 \pm 0.443$ & $41.832 \pm 0.648$ & $41.463 \pm 1.135$ \\
\hline \multicolumn{7}{|l|}{ Lung } \\
\hline Absolute & $0.227 \pm 0.005$ & $0.240 \pm 0.007$ & $0.230 \pm 0.003$ & $0.231 \pm 0.003$ & $0.233 \pm 0.004$ & $0.216 \pm 0.006$ \\
\hline Relative & $6.039 \pm 0.105$ & $6.277 \pm 0.193$ & $6.145 \pm 0.145$ & $5.997 \pm 0.096$ & $6.096 \pm 0.125$ & $6.768 \pm 0.130 * *$ \\
\hline \multicolumn{7}{|l|}{ R. Testis } \\
\hline Absolute & $0.123 \pm 0.002$ & $0.117 \pm 0.003$ & $0.120 \pm 0.002$ & $0.131 \pm 0.005$ & $0.119 \pm 0.003$ & $0.120 \pm 0.002$ \\
\hline Relative & $3.272 \pm 0.095$ & $3.068 \pm 0.102$ & $3.211 \pm 0.083$ & $3.397 \pm 0.138$ & $3.114 \pm 0.065$ & $3.783 \pm 0.117 * *$ \\
\hline \multicolumn{7}{|l|}{ Thymus } \\
\hline Absolute & $0.052 \pm 0.003$ & $0.048 \pm 0.002$ & $0.049 \pm 0.002$ & $0.052 \pm 0.003$ & $0.049 \pm 0.002$ & $0.038 \pm 0.002 * *$ \\
\hline Relative & $1.395 \pm 0.097$ & $1.256 \pm 0.069$ & $1.317 \pm 0.063$ & $1.349 \pm 0.066$ & $1.267 \pm 0.055$ & $1.182 \pm 0.050$ \\
\hline
\end{tabular}

\section{Female}

Necropsy body wt $\quad 32.8 \pm 0.8 \quad 32.8 \pm 0.9 \quad 31.4 \pm 0.8 \quad 33.7 \pm 0.5 \quad 33.0 \pm 0.4 \quad 29.3 \pm 0.5^{* *}$

Heart
Absolute
$\begin{array}{llllll}0.140 \pm 0.003 & 0.152 \pm 0.003 * & 0.148 \pm 0.003 & 0.148 \pm 0.002 & 0.156 \pm 0.004 * * & 0.140 \pm 0.003\end{array}$
Relative
$4.279 \pm 0.099 \quad 4.644 \pm 0.074 \quad 4.731 \pm 0.139 * 4.397 \pm 0.091 \quad 4.733 \pm 0.135 * 4.782 \pm 0.077 * *$
R. Kidney
Absolute
$0.210 \pm 0.006 \quad 0.217 \pm 0.003 \quad 0.213 \pm 0.005 \quad 0.214 \pm 0.004$
$0.216 \pm 0.006 \quad 0.200 \pm 0.005$
Relative
$6.409 \pm 0.165 \quad 6.661 \pm 0.220$
$6.794 \pm 0.130 \quad 6.357 \pm 0.141$
$6.537 \pm 0.125 \quad 6.826 \pm 0.087$
Liver

\begin{tabular}{lcccccc} 
Absolute & $1.531 \pm 0.039$ & $1.512 \pm 0.056$ & $1.489 \pm 0.043$ & $1.499 \pm 0.042$ & $1.533 \pm 0.022$ & $1.312 \pm 0.031 * *$ \\
Relative & $46.716 \pm 0.855$ & $46.059 \pm 0.914$ & $47.406 \pm 0.683$ & $44.465 \pm 1.056$ & $46.451 \pm 0.618$ & $44.794 \pm 0.557$ \\
\hline
\end{tabular}


Triethylamine, NTP TOX 78

\begin{tabular}{lcccccc}
\hline & $\begin{array}{c}\text { Chamber } \\
\text { Control }\end{array}$ & $\mathbf{1 2 . 5} \mathbf{~ p p m}$ & $\mathbf{2 5} \mathbf{~ p p m}$ & $\mathbf{5 0} \mathbf{~ p p m}$ & $\mathbf{1 0 0} \mathbf{~ p p m}$ & $\mathbf{2 0 0} \mathbf{~ p p m}$ \\
\hline Lung & & & & & & \\
Absolute & $0.229 \pm 0.004$ & $0.245 \pm 0.012$ & $0.225 \pm 0.006$ & $0.234 \pm 0.007$ & $0.248 \pm 0.010$ & $0.229 \pm 0.007$ \\
$\quad \begin{array}{l}\text { Relative } \\
\text { Thymus }\end{array}$ & $7.011 \pm 0.204$ & $7.504 \pm 0.384$ & $7.204 \pm 0.268$ & $6.956 \pm 0.221$ & $7.519 \pm 0.327$ & $7.832 \pm 0.250$ \\
Absolute & & & & & & \\
Relative & $1.055 \pm 0.003$ & $0.059 \pm 0.003$ & $0.064 \pm 0.012$ & $0.057 \pm 0.002$ & $0.054 \pm 0.003$ & $0.048 \pm 0.002$ \\
\hline
\end{tabular}

*Significantly different $(\mathrm{P} \leq 0.05)$ from the chamber control group by Dunnett's test.

**Significantly different $(\mathrm{P} \leq 0.01)$ from the chamber control group by Williams' or Dunnett's test.

${ }^{\mathrm{a}}$ Organ weights (absolute weights) and body weights are given in grams; organ-weight-to-body-weight ratios (relative weights) are given as $\mathrm{mg}$ organ weight/g body weight (mean \pm standard error). 


\section{Appendix E. Reproductive Tissue Evaluations and Estrous Cycle Characterization}

\section{Tables}

Table E-1. Summary of Reproductive Tissue Evaluations for Male Rats in the

Three-month Inhalation Study of Triethylamine

Table E-2. Estrous Cycle Characterization for Female Rats in theThree-month Inhalation

Study of Triethylamine

Table E-3. Results of Vaginal Cytology Study Using the Transition Matrix Approach in Female Rats Administered Triethylamine by Inhalation for Three Months

Table E-4. Summary of Reproductive Tissue Evaluations for Male Mice in the Threemonth Inhalation Study of Triethylamine

Table E-5. Estrous Cycle Characterization for Female Mice in the Three-month Inhalation Study of Triethylamine.

Table E-6. Results of Vaginal Cytology Study Using the Transition Matrix Approach in Female Mice Administered Triethylamine by Inhalation for Three Months

\section{Figures}

Figure E-1. Vaginal Cytology Plots for Female Rats in the Three-month Inhalation Study of Triethylamine

Figure E-2. Vaginal Cytology Plots for Female Mice in the Three-month Inhalation Study of Triethylamine 
Table E-1. Summary of Reproductive Tissue Evaluations for Male Rats in the Three-month Inhalation Study of Triethylamine ${ }^{a}$

\begin{tabular}{|c|c|c|c|c|}
\hline & $\begin{array}{l}\text { Chamber } \\
\text { Control }\end{array}$ & 50 ppm & 100 ppm & 200 ppm \\
\hline $\mathbf{n}$ & 10 & 10 & 10 & 10 \\
\hline \multicolumn{5}{|l|}{ Weights (g) } \\
\hline Necropsy body wt & $347 \pm 7$ & $352 \pm 8$ & $338 \pm 4$ & $300 \pm 5^{* *}$ \\
\hline L. Cauda epididymis & $0.1820 \pm 0.0037$ & $0.1908 \pm 0.0053$ & $0.1850 \pm 0.0029$ & $0.1734 \pm 0.0045$ \\
\hline L. Epididymis & $0.4871 \pm 0.0079$ & $0.4915 \pm 0.0078$ & $0.4913 \pm 0.0053$ & $0.4684 \pm 0.0060$ \\
\hline L. Testis & $1.4762 \pm 0.0205$ & $1.4897 \pm 0.0140$ & $1.4572 \pm 0.0206$ & $1.4254 \pm 0.0163$ \\
\hline \multicolumn{5}{|l|}{ Spermatid measurements } \\
\hline Spermatid heads $\left(10^{3} / \mathrm{mg}\right.$ testis $)$ & $126.3 \pm 3.1$ & $134.0 \pm 2.3$ & $138.8 \pm 4.4^{* *}$ & $139.2 \pm 3.4^{*}$ \\
\hline Spermatid heads $\left(10^{6} /\right.$ testis $)$ & $172.6 \pm 4.2$ & $183.0 \pm 3.9$ & $185.9 \pm 5.0$ & $181.0 \pm 4.5$ \\
\hline \multicolumn{5}{|l|}{ Epididymal spermatozoal measurements } \\
\hline Sperm motility (\%) & $91.81 \pm 0.82$ & $88.63 \pm 0.83 *$ & $87.75 \pm 0.85^{* *}$ & $86.26 \pm 1.45^{* *}$ \\
\hline Sperm $\left(10^{3} / \mathrm{mg}\right.$ cauda epididymis $)$ & $700.4 \pm 38.9$ & $641.5 \pm 34.9$ & $631.6 \pm 19.7$ & $664.3 \pm 30.3$ \\
\hline Sperm (10\%/cauda epididymis) & $126.7 \pm 5.5$ & $121.4 \pm 5.3$ & $116.4 \pm 2.3$ & $115.0 \pm 5.7$ \\
\hline
\end{tabular}

*Significantly different $(\mathrm{P} \leq 0.05)$ from the chamber control group by Shirley's test (motility and spermatid heads/mg testis measurements).

**Significantly different $(\mathrm{P} \leq 0.01)$ from the chamber control group by Williams' test (body weights) or Shirley’s test (motility and spermatid heads/mg testis measurements).

a Data are presented as mean \pm standard error. Differences from the chamber control group are not significant by Dunnett's test (tissue weights) or Dunn's test (spermatid heads/testis, sperm/mg cauda epididymis, and sperm/cauda epididymis measurements). 
Triethylamine, NTP TOX 78

Table E-2. Estrous Cycle Characterization for Female Rats in theThree-month Inhalation Study of Triethylamine $^{\mathrm{a}}$

\begin{tabular}{lcccc}
\hline & $\begin{array}{c}\text { Chamber } \\
\text { Control }\end{array}$ & $\mathbf{5 0 ~} \mathbf{~ p p m}$ & $\mathbf{1 0 0} \mathbf{~ p p m}$ & $\mathbf{2 0 0} \mathbf{~ p p m}$ \\
\hline Number weighed at necropsy & 10 & 10 & 10 & 10 \\
$\quad$ Necropsy body wt (g) & $209 \pm 4$ & $207 \pm 5$ & $198 \pm 5$ & $181 \pm 3^{* *}$ \\
Proportion of regular cycling females ${ }^{\mathrm{b}}$ & $10 / 10$ & $10 / 10$ & $9 / 10$ & $9 / 10$ \\
Estrous cycle length (days) & $4.95 \pm 0.05$ & $5.00 \pm 0.00$ & $4.78 \pm 0.15^{\mathrm{c}}$ & $4.70 \pm 0.31$ \\
Estrous stages (\% of cycle) & & & & \\
Diestrus & 55.0 & 57.5 & 54.2 & 50.0 \\
Proestrus & 19.2 & 17.5 & 15.0 & 14.2 \\
Estrus & 21.7 & 20.0 & 20.8 & 25.0 \\
Metestrus & 3.3 & 5.0 & 10.0 & 10.8 \\
Uncertain diagnosis & 0.8 & 0.0 & 0.0 & 0.0 \\
\hline
\end{tabular}

**Significantly different $(\mathrm{P} \leq 0.01)$ from the chamber control group by Williams' test.

${ }^{a}$ Necropsy body weights and estrous cycle length data are presented as mean \pm standard error. Differences from the chamber control group are not significant by Dunn's test (estrous cycle length). Evidence shows that females exposed to 200 ppm differ significantly (Wilk's Criterion, $\mathrm{P} \leq 0.05$ ) from the chamber control females in the relative length of time spent in the estrous stages. Females exposed to $200 \mathrm{ppm}$ spent more time in metestrus than chamber control females.

${ }^{b}$ Number of females with a regular cycle/number of females cycling.

${ }^{\mathrm{c} E s t r o u s ~ c y c l e ~ w a s ~ l o n g e r ~ t h a n ~} 12$ days or unclear in 1 of 10 animals. 
Table E-3. Results of Vaginal Cytology Study Using the Transition Matrix Approach in Female Rats Administered Triethylamine by Inhalation for Three Months

\begin{tabular}{|c|c|c|c|}
\hline Stage & Comparison & P Value & Trend $^{a}$ \\
\hline Overall tests & Overall & 0.785 & \\
\hline Overall tests & 50 ppm vs. chamber controls & 0.811 & - \\
\hline Overall tests & 100 ppm vs. chamber controls & 0.392 & $\mathrm{~N}$ \\
\hline Overall tests & 200 ppm vs. chamber controls & 0.639 & $\mathrm{~N}$ \\
\hline Extended estrus & Overall & 0.404 & \\
\hline Extended estrus & 50 ppm vs. chamber controls & 0.353 & - \\
\hline Extended estrus & 100 ppm vs. chamber controls & 0.604 & - \\
\hline Extended estrus & 200 ppm vs. chamber controls & 0.214 & - \\
\hline Extended diestrus & Overall & 0.407 & \\
\hline Extended diestrus & 50 ppm vs. chamber controls & 0.917 & $\mathrm{~N}$ \\
\hline Extended diestrus & 100 ppm vs. chamber controls & 0.286 & $\mathrm{~N}$ \\
\hline Extended diestrus & 200 ppm vs. chamber controls & 0.176 & $\mathrm{~N}$ \\
\hline Extended metestrus & Overall & 1 & \\
\hline Extended metestrus & 50 ppm vs. chamber controls & 1 & - \\
\hline Extended metestrus & 100 ppm vs. chamber controls & 1 & - \\
\hline Extended metestrus & 200 ppm vs. chamber controls & 1 & - \\
\hline Extended proestrus & Overall & 1 & \\
\hline Extended proestrus & 50 ppm vs. chamber controls & 1 & - \\
\hline Extended proestrus & 100 ppm vs. chamber controls & 1 & - \\
\hline Extended proestrus & 200 ppm vs. chamber controls & 1 & - \\
\hline Skipped estrus & Overall & 1 & \\
\hline Skipped estrus & 50 ppm vs. chamber controls & 1 & - \\
\hline Skipped estrus & 100 ppm vs. chamber controls & 1 & - \\
\hline Skipped estrus & 200 ppm vs. chamber controls & 1 & - \\
\hline Skipped diestrus & Overall & 1 & \\
\hline Skipped diestrus & 50 ppm vs. chamber controls & 1 & - \\
\hline Skipped diestrus & 100 ppm vs. chamber controls & 1 & - \\
\hline Skipped diestrus & 200 ppm vs. chamber controls & 1 & - \\
\hline
\end{tabular}


Table E-4. Summary of Reproductive Tissue Evaluations for Male Mice in the Three-month Inhalation Study of Triethylamine ${ }^{a}$

\begin{tabular}{|c|c|c|c|c|}
\hline & $\begin{array}{l}\text { Chamber } \\
\text { Control }\end{array}$ & 50 ppm & 100 ppm & 200 ppm \\
\hline n & 10 & 10 & 10 & 10 \\
\hline \multicolumn{5}{|l|}{ Weights (g) } \\
\hline Necropsy body wt & $37.6 \pm 0.8$ & $38.6 \pm 0.5$ & $38.3 \pm 0.6$ & $31.9 \pm 0.6^{* *}$ \\
\hline L. Cauda epididymis & $0.0193 \pm 0.0006$ & $0.0162 \pm 0.0008 * *$ & $0.0176 \pm 0.0008$ & $0.0173 \pm 0.0005$ \\
\hline L. Epididymis & $0.0544 \pm 0.0012$ & $0.0532 \pm 0.0006$ & $0.0540 \pm 0.0013$ & $0.0487 \pm 0.0010^{* *}$ \\
\hline L. Testis & $0.1135 \pm 0.0013$ & $0.1108 \pm 0.0023$ & $0.1099 \pm 0.0027$ & $0.1074 \pm 0.0015$ \\
\hline \multicolumn{5}{|l|}{ Spermatid measurements } \\
\hline Spermatid heads $\left(10^{3} / \mathrm{mg}\right.$ testis $)$ & $185.2 \pm 4.9$ & $196.6 \pm 6.0$ & $188.4 \pm 7.1$ & $200.4 \pm 6.0$ \\
\hline Spermatid heads $\left(10^{6} /\right.$ testis $)$ & $19.42 \pm 0.47$ & $20.47 \pm 0.76$ & $19.29 \pm 0.63$ & $19.74 \pm 0.49$ \\
\hline \multicolumn{5}{|l|}{ Epididymal spermatozoal measurements } \\
\hline Sperm motility (\%) & $88.24 \pm 1.04$ & $85.47 \pm 0.84$ & $85.52 \pm 0.51$ & $86.50 \pm 0.91$ \\
\hline Sperm ( $10^{3} / \mathrm{mg}$ cauda epididymis $)$ & $1,058 \pm 41$ & $1,007 \pm 52$ & $1,007 \pm 70$ & $1,023 \pm 70$ \\
\hline Sperm (10\%/cauda epididymis) & $20.35 \pm 0.59$ & $16.03 \pm 0.48^{* *}$ & $17.39 \pm 0.78$ & $17.59 \pm 1.10$ \\
\hline
\end{tabular}


Table E-5. Estrous Cycle Characterization for Female Mice in the Three-month Inhalation Study of Triethylamine $^{\mathrm{a}}$

\begin{tabular}{lcccc}
\hline & $\begin{array}{c}\text { Chamber } \\
\text { Control }\end{array}$ & $\mathbf{5 0 ~} \mathbf{~ p p m}$ & $\mathbf{1 0 0} \mathbf{~ p p m}$ & $\mathbf{2 0 0} \mathbf{~ p p m}$ \\
\hline Number weighed at necropsy & 10 & 10 & 10 & 10 \\
$\quad$ Necropsy body wt (g) & $32.8 \pm 0.8$ & $33.7 \pm 0.5$ & $33.0 \pm 0.4$ & $29.3 \pm 0.5^{* *}$ \\
Proportion of regular cycling females ${ }^{\mathrm{b}}$ & $10 / 10$ & $7 / 10$ & $9 / 10$ & $6 / 10^{*}$ \\
Estrous cycle length (days) & $4.05 \pm 0.05$ & $4.20 \pm 0.11$ & $4.00 \pm 0.00^{\mathrm{c}}$ & $4.20 \pm 0.19$ \\
Estrous stages (\% of cycle) & & & & \\
Diestrus & 26.7 & 24.2 & 30.0 & 29.2 \\
Proestrus & 0.0 & 0.0 & 0.0 & 0.0 \\
Estrus & 48.3 & 51.7 & 46.7 & 47.5 \\
Metestrus & 25.0 & 24.2 & 23.3 & 23.3 \\
\hline
\end{tabular}

*Significantly different $(\mathrm{P} \leq 0.05)$ from the chamber control group by Dunn's test (proportion of regular cycling females). **Significantly different $(\mathrm{P} \leq 0.01)$ from the chamber control group by Williams' test (body weights).

${ }^{a}$ Necropsy body weights and estrous cycle length data are presented as mean \pm standard error. Differences from the chamber control group are not significant by Dunn's test (estrous cycle length). By multivariate analysis of variance, exposed females do not differ significantly from the chamber control females in the relative length of time spent in the estrous stages.

${ }^{b}$ Number of females with a regular cycle/number of females cycling.

${ }^{c}$ Estrous cycle was longer than 12 days or unclear in 1 of 10 animals. 
Table E-6. Results of Vaginal Cytology Study Using the Transition Matrix Approach in Female Mice Administered Triethylamine by Inhalation for Three Months

\begin{tabular}{|c|c|c|c|}
\hline Stage & Comparison & P Value & Trend $^{\mathrm{a}}$ \\
\hline Overall tests & Overall & 0.232 & \\
\hline Overall tests & 50 ppm vs. chamber controls & 0.207 & - \\
\hline Overall tests & 100 ppm vs. chamber controls & 0.167 & - \\
\hline Overall tests & 200 ppm vs. chamber controls & 0.508 & - \\
\hline Extended estrus & Overall & 0.211 & \\
\hline Extended estrus & 50 ppm vs. chamber controls & 0.207 & - \\
\hline Extended estrus & 100 ppm vs. chamber controls & 1 & - \\
\hline Extended estrus & 200 ppm vs. chamber controls & 0.073 & - \\
\hline Extended diestrus & Overall & 0.597 & \\
\hline Extended diestrus & 50 ppm vs. chamber controls & 1 & - \\
\hline Extended diestrus & 100 ppm vs. chamber controls & 0.167 & - \\
\hline Extended diestrus & 200 ppm vs. chamber controls & 0.604 & - \\
\hline Extended metestrus & Overall & 1 & \\
\hline Extended metestrus & 50 ppm vs. chamber controls & 1 & - \\
\hline Extended metestrus & 100 ppm vs. chamber controls & 1 & - \\
\hline Extended metestrus & 200 ppm vs. chamber controls & 1 & - \\
\hline Extended proestrus & Overall & 1 & \\
\hline Extended proestrus & 50 ppm vs. chamber controls & 1 & - \\
\hline Extended proestrus & 100 ppm vs. chamber controls & 1 & - \\
\hline Extended proestrus & 200 ppm vs. chamber controls & 1 & - \\
\hline Skipped estrus & Overall & 1 & \\
\hline Skipped estrus & 50 ppm vs. chamber controls & 1 & - \\
\hline Skipped estrus & 100 ppm vs. chamber controls & 1 & - \\
\hline Skipped estrus & 200 ppm vs. chamber controls & 1 & - \\
\hline Skipped diestrus & Overall & 1 & \\
\hline Skipped diestrus & 50 ppm vs. chamber controls & 1 & - \\
\hline Skipped diestrus & 100 ppm vs. chamber controls & 1 & - \\
\hline Skipped diestrus & 200 ppm vs. chamber controls & 1 & - \\
\hline
\end{tabular}




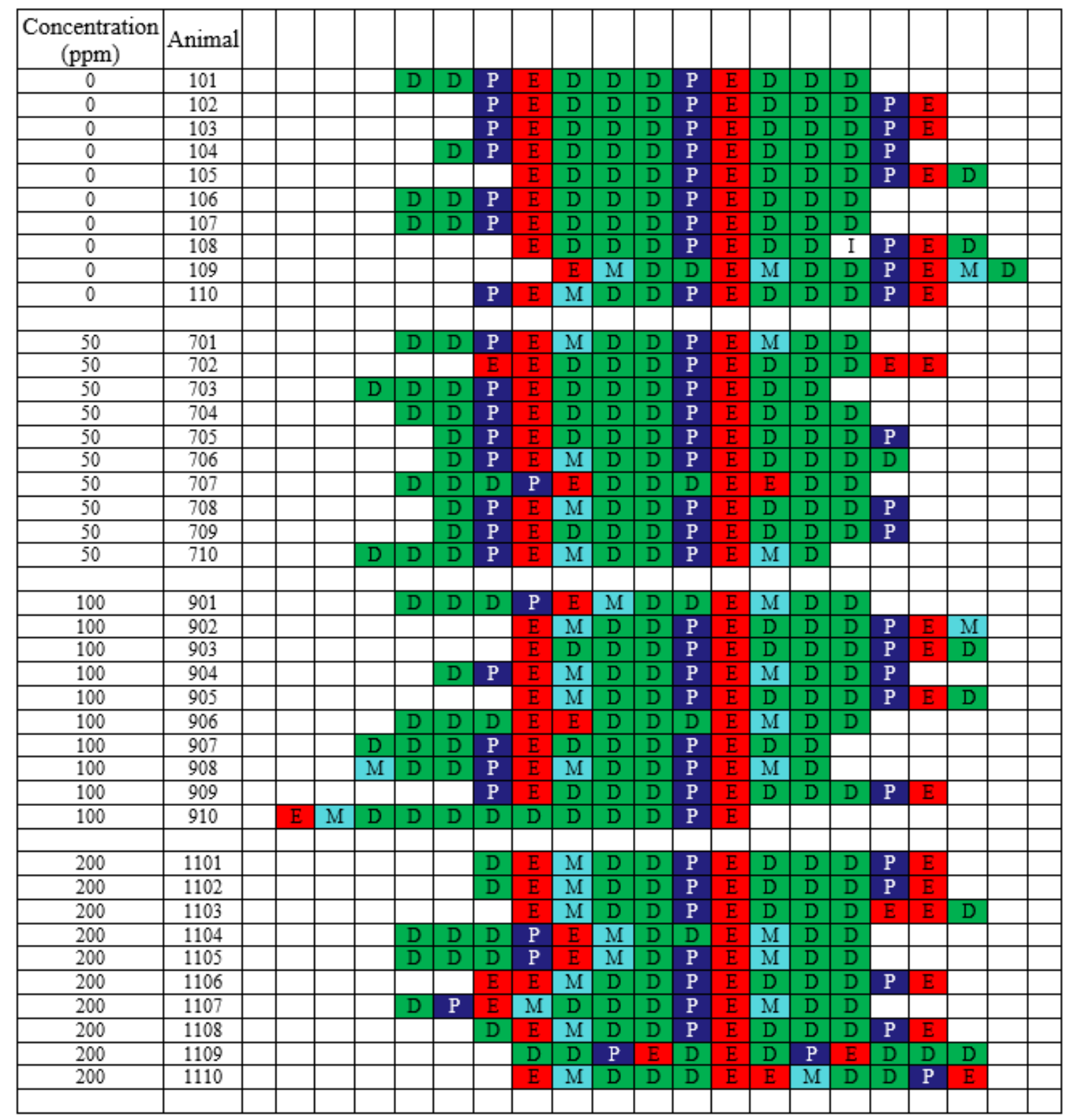

Figure E-1. Vaginal Cytology Plots for Female Rats in the Three-month Inhalation Study of Triethylamine

$\mathrm{I}=$ insufficient number of cells to determine state, $\mathrm{D}=$ diestrus, $\mathrm{P}=$ proestrus, $\mathrm{E}=$ estrus, $\mathrm{M}=$ metestrus. 


\begin{tabular}{|c|c|c|c|c|c|c|c|c|c|c|c|c|c|c|c|c|c|c|c|c|c|c|}
\hline $\begin{array}{c}\text { Concentration } \\
(\mathrm{ppm})\end{array}$ & Animal & & & & & & & & & & & & & & & & & & & & & \\
\hline 0 & 101 & & & & & & & D & E & $E$ & $\mathrm{M}$ & $\mathrm{D}$ & $E$ & $E$ & $\mathrm{M}$ & $\mathrm{D}$ & $E$ & $E$ & $\mathrm{M}$ & & & \\
\hline 0 & 102 & & & & & & & & & $E$ & $\mathrm{M}$ & $\mathrm{D}$ & $E$ & $E$ & $\mathrm{M}$ & $\mathrm{D}$ & E & $E$ & $\mathrm{M}$ & $\mathrm{D}$ & $\mathrm{E}$ & \\
\hline 0 & 103 & & & & & & $\mathrm{M}$ & $\mathrm{D}$ & E & $E$ & $\mathrm{M}$ & $\mathrm{D}$ & $E$ & $E$ & $\mathrm{M}$ & $\mathrm{D}$ & $E$ & $E$ & & & & \\
\hline 0 & 104 & & & & & & & & E & $E$ & $\mathrm{M}$ & $\mathrm{D}$ & $E$ & $E$ & $\mathrm{M}$ & $\mathrm{D}$ & $E$ & $E$ & $\mathrm{M}$ & D & & \\
\hline 0 & 105 & & & & & & & & E & $E$ & $\mathrm{M}$ & $\mathrm{D}$ & $E$ & $E$ & $\mathrm{M}$ & $\mathrm{D}$ & E & $E$ & $\mathrm{M}$ & D & & \\
\hline 0 & 106 & & & & & $\mathrm{M}$ & D & $E$ & E & $\mathrm{M}$ & $\mathrm{D}$ & $\mathrm{D}$ & $E$ & $E$ & $\mathrm{M}$ & $\mathrm{D}$ & $\mathrm{D}$ & 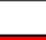 & & & & \\
\hline 0 & 107 & & & & & & & D & $E$ & $E$ & $\mathrm{M}$ & $\mathrm{D}$ & $E$ & $E$ & $\mathrm{M}$ & $\mathrm{D}$ & $E$ & $E$ & $\mathrm{M}$ & & & \\
\hline 0 & 108 & & & & & & & & E & $E$ & $\mathrm{M}$ & $\mathrm{D}$ & $E$ & $\mathrm{E}$ & $\mathrm{M}$ & $\mathrm{D}$ & $E$ & $E$ & $\mathrm{M}$ & D & & \\
\hline 0 & 109 & & & & & & & & 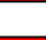 & $E$ & $\mathrm{M}$ & $\mathrm{D}$ & $E$ & $E$ & $\mathrm{M}$ & $\mathrm{D}$ & E & $E$ & $\mathrm{M}$ & $\mathrm{D}$ & $E$ & \\
\hline 0 & 110 & & & & & & & & $\mathrm{E}$ & $\mathrm{E}$ & $\mathrm{M}$ & $\mathrm{D}$ & $E$ & $\mathrm{E}$ & $\mathrm{M}$ & $\mathrm{D}$ & $\mathrm{E}$ & $E$ & $\mathrm{M}$ & $\mathrm{D}$ & & \\
\hline & & & & & & & & & & & & & & & & & & & & & & \\
\hline 50 & 701 & & & & & & & D & $E$ & E & $\mathrm{M}$ & D & $E$ & $E$ & $\mathrm{M}$ & $\mathrm{D}$ & E & E & $E$ & & & \\
\hline 50 & 702 & & & & & & & & $\mathrm{E}$ & $E$ & $\mathrm{M}$ & $\mathrm{D}$ & $\mathrm{E}$ & $\mathrm{E}$ & $\mathrm{M}$ & $\mathrm{D}$ & $E$ & $\mathrm{E}$ & $\mathrm{E}$ & $\mathrm{M}$ & & \\
\hline 50 & 703 & & & & & & & D & E & $E$ & $\mathrm{M}$ & $\mathrm{D}$ & $E$ & $E$ & $\mathrm{M}$ & $\mathrm{D}$ & E & $E$ & $\mathrm{M}$ & & & \\
\hline 50 & 704 & & & & & & & & E & $E$ & $\mathrm{M}$ & $\mathrm{D}$ & $E$ & $E$ & $\mathrm{M}$ & $\mathrm{D}$ & E & $E$ & $\mathrm{M}$ & $\mathrm{D}$ & & \\
\hline 50 & 705 & & & & & & $\mathrm{M}$ & $\mathrm{D}$ & $E$ & $E$ & $\mathrm{M}$ & D & $E$ & $E$ & $\mathrm{M}$ & $\mathrm{D}$ & $\mathrm{E}$ & E & & & & \\
\hline 50 & 706 & & & & & & & $\mathrm{D}$ & $E$ & $E$ & $\mathrm{M}$ & $\mathrm{D}$ & $E$ & $\mathrm{E}$ & $\mathrm{M}$ & $\mathrm{D}$ & $E$ & E & $\mathrm{M}$ & & & \\
\hline 50 & 707 & & & & & $\mathrm{M}$ & D & $E$ & $E$ & $E$ & $\mathrm{M}$ & D & $E$ & $E$ & $E$ & $\mathrm{M}$ & D & 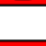 & & & & \\
\hline 50 & 708 & & & & & & & $\mathrm{D}$ & $\mathrm{E}$ & $E$ & $\mathrm{M}$ & $\mathrm{D}$ & $E$ & $E$ & $\mathrm{M}$ & $\mathrm{D}$ & $E$ & $\mathrm{E}$ & $\mathrm{M}$ & & & \\
\hline 50 & 709 & & & & & & & & E & $E$ & $\mathrm{M}$ & $\mathrm{D}$ & $E$ & $E$ & $\mathrm{M}$ & $\mathrm{D}$ & $E$ & E & $\mathrm{M}$ & $\mathrm{D}$ & & \\
\hline 50 & 710 & & & & & & & & & $E$ & $\mathrm{M}$ & $\mathrm{D}$ & $\mathrm{E}$ & $\mathrm{E}$ & $\mathrm{M}$ & D & E & E & $\mathrm{M}$ & D & $E$ & \\
\hline & & & & & & & & & & 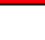 & & & 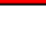 & 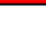 & & & - & 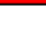 & & & & \\
\hline 100 & 901 & & & & & & & & $\mathrm{E}$ & $E$ & $\mathrm{M}$ & $\mathrm{D}$ & $E$ & E & $\mathrm{M}$ & $\mathrm{D}$ & E & $E$ & $\mathrm{M}$ & $\mathrm{D}$ & & \\
\hline 100 & 902 & & & & & & & & & $E$ & $\mathrm{M}$ & $\mathrm{D}$ & $E$ & $E$ & $\mathrm{M}$ & $\mathrm{D}$ & E & E & $\mathrm{M}$ & $\mathrm{D}$ & $E$ & \\
\hline 100 & 903 & & & & & & & & $E$ & $E$ & $\mathrm{M}$ & D & $E$ & $E$ & $\mathrm{M}$ & $\mathrm{D}$ & E & $E$ & $\mathrm{M}$ & D & & \\
\hline 100 & 904 & & & & & & & & 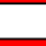 & $E$ & $\mathrm{M}$ & $\mathrm{D}$ & $E$ & $E$ & $\mathrm{M}$ & $\mathrm{D}$ & $E$ & $E$ & $\mathrm{M}$ & $\mathrm{D}$ & $E$ & \\
\hline 100 & 905 & & & & & & $\mathrm{M}$ & D & $E$ & $E$ & $\mathrm{M}$ & D & $E$ & E & $\mathrm{M}$ & D & E & $E$ & & & & \\
\hline 100 & 906 & & & & & & & $\mathrm{D}$ & $\mathrm{E}$ & $\mathrm{E}$ & $\mathrm{M}$ & $\mathrm{D}$ & $E$ & $E$ & $\mathrm{M}$ & $\mathrm{D}$ & $E$ & $E$ & $\mathrm{M}$ & & & \\
\hline 100 & 907 & & & & & & & & E & $E$ & $\mathrm{M}$ & $\mathrm{D}$ & $E$ & $E$ & $\mathrm{M}$ & $\mathrm{D}$ & $E$ & $E$ & $\mathrm{M}$ & D & & \\
\hline 100 & 908 & & & & & & & & & $E$ & $\mathrm{M}$ & $\mathrm{D}$ & $E$ & $E$ & $\mathrm{M}$ & D & E & $E$ & $\mathrm{M}$ & D & $E$ & \\
\hline 100 & 909 & $E$ & $\mathrm{M}$ & $\mathrm{D}$ & $\mathrm{D}$ & $\mathrm{D}$ & $\mathrm{D}$ & $\mathrm{D}$ & $\mathrm{D}$ & $\mathrm{D}$ & $\mathrm{D}$ & $\mathrm{D}$ & $E$ & 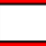 & & & & 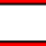 & & & & \\
\hline 100 & 910 & & & & & & & & & E & $\mathrm{M}$ & $\mathrm{D}$ & E & $\mathrm{E}$ & $\mathrm{M}$ & $\mathrm{D}$ & $E$ & $\mathrm{E}$ & $\mathrm{M}$ & $\mathrm{D}$ & $E$ & \\
\hline & & & & & & & & & & & & & & & & & & & & & & \\
\hline 200 & 1101 & & & & & & & & $E$ & $E$ & $\mathrm{M}$ & $\mathrm{D}$ & $E$ & $E$ & $\mathrm{M}$ & $\mathrm{D}$ & E & E & $\mathrm{M}$ & D & & \\
\hline 200 & 1102 & $\mathrm{D}$ & $\mathrm{D}$ & $\mathrm{D}$ & $\mathrm{D}$ & $\mathrm{D}$ & $\mathrm{D}$ & $E$ & $E$ & $E$ & $\mathrm{M}$ & $\mathrm{D}$ & $E$ & 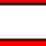 & & - & 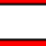 & 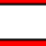 & & & & \\
\hline 200 & 1103 & & & & & & & D & E & $E$ & $\mathrm{M}$ & D & $E$ & $E$ & $\mathrm{M}$ & D & $E$ & $E$ & $\mathrm{M}$ & & & \\
\hline 200 & 1104 & & & & & & & & & $\mathrm{E}$ & $\mathrm{M}$ & $\mathrm{D}$ & $E$ & $\mathrm{E}$ & $\mathrm{M}$ & $\mathrm{D}$ & $E$ & $\mathrm{E}$ & $\mathrm{M}$ & $\mathrm{D}$ & $\mathrm{E}$ & \\
\hline 200 & 1105 & & & & & $\mathrm{M}$ & $\mathrm{D}$ & $E$ & $E$ & $E$ & $\mathrm{M}$ & $\mathrm{D}$ & $E$ & $E$ & $E$ & $\mathrm{M}$ & D & 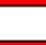 & & & & \\
\hline 200 & 1106 & & & & & & & & $E$ & $\mathrm{M}$ & $\mathrm{D}$ & $\mathrm{D}$ & $E$ & $E$ & $\mathrm{M}$ & $\mathrm{D}$ & $E$ & E & $\mathrm{M}$ & $\mathrm{D}$ & & \\
\hline 200 & 1107 & & & & & & & & & $E$ & $\mathrm{M}$ & $\mathrm{D}$ & $E$ & $E$ & $E$ & $\mathrm{M}$ & D & D & E & $E$ & $\mathrm{M}$ & \\
\hline 200 & 1108 & & & & & & & & & $E$ & $\mathrm{M}$ & $\mathrm{D}$ & $E$ & $E$ & $\mathrm{E}$ & $\mathrm{M}$ & $\mathrm{D}$ & $E$ & $E$ & $\mathrm{M}$ & $\mathrm{D}$ & \\
\hline 200 & 1109 & & & & & & $\mathrm{M}$ & D & $E$ & $E$ & $\mathrm{M}$ & $\mathrm{D}$ & $E$ & $E$ & $\mathrm{M}$ & $\mathrm{D}$ & $E$ & $E$ & & & & \\
\hline 200 & 1110 & & & & & & & & & $\mathrm{E}$ & $\mathrm{M}$ & $\mathrm{D}$ & E & E & $\mathrm{M}$ & $\mathrm{D}$ & E & E & $\mathrm{M}$ & $\mathrm{D}$ & $E$ & \\
\hline & & & & & & & & & & & & & & & & & & & & & & \\
\hline
\end{tabular}

Figure E-2. Vaginal Cytology Plots for Female Mice in the Three-month Inhalation Study of Triethylamine

$\mathrm{D}=$ diestrus, $\mathrm{E}=$ estrus, $\mathrm{M}=$ metestrus. 


\section{Appendix F. Chemical Characterization and Generation of Chamber Concentrations}

\section{Table of Contents}

F.1. Procurement and Characterization of Triethylamine................................................... F-2

F.2. Vapor Generation and Exposure System ................................................................F-2

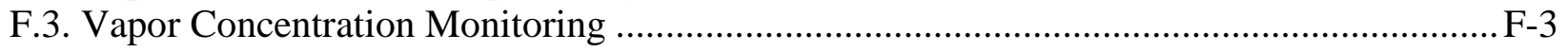

F.4. Chamber Atmosphere Characterization .........................................................................

\section{Tables}

Table F-1. Gas Chromatography Systems Used in the Inhalation Studies of Triethylamine ...... F-5

Table F-2. Summary of Chamber Concentrations in the Two-week Inhalation Studies of Triethylamine

Table F-3. Summary of Chamber Concentrations in the Three-month Inhalation Studies of Triethylamine F-6

\section{Figures}

Figure F-1. Infrared Absorption Spectrum of Triethylamine .............................................F-8

Figure F-2. Proton Nuclear Magnetic Resonance Spectrum of Triethylamine .........................F-9

Figure F-3. Low Resolution Mass Spectrum of Triethylamine ..........................................F-10

Figure F-4. Schematic of the Vapor Generation and Delivery System in the Inhalation Studies of Triethylamine 


\section{F.1. Procurement and Characterization of Triethylamine}

Triethylamine was obtained from Alkyl Amines Chemicals, Limited (Maharashtra, India) in one lot $(\mathrm{CE} / 04 / 01)$ that was used in the 2-week and 3-month studies. Identity and purity analyses were conducted by the analytical chemistry laboratories at Chemir/Polytech Laboratories, Inc. (Maryland Heights, MO), Galbraith Laboratories, Inc., (Knoxville, TN), and Research Triangle Institute (RTI) (Research Triangle Park, NC), and by the study laboratory at Battelle Toxicology Northwest (Richland, WA). Reports on analyses performed in support of the triethylamine studies are on file at the National Institute of Environmental Health Sciences.

Lot CE/04/01 of the chemical, a highly alkaline colorless liquid with a strong ammonia odor, was identified as triethylamine by Chemir/Polytech, Inc., and RTI using fourier transform infrared (IR) and proton nuclear magnetic resonance (NMR) spectroscopy. RTI also used gas chromatography (GC) with mass spectrometry (MS) to confirm the identification. All spectra were consistent with the literature spectra ${ }^{78 ; 79}$ and the structure of triethylamine. Representative IR, proton NMR, and mass spectra are presented in Figure F-1, Figure F-2, and Figure F-3, respectively.

Chemir/Polytech Laboratories, Inc. determined the moisture content of lot CE/04/01 using Karl Fischer titration. Galbraith Laboratories, Inc., measured the purity of the bulk chemical by elemental analyses. The purity of lot CE/04/01 was also determined by RTI and the study laboratory using GC with flame ionization detection (FID) by systems A and B, respectively (Table F-1).

For lot CE/04/01, Karl Fischer titration indicated $221 \mathrm{ppm}$ water. Elemental analyses for carbon, hydrogen, and nitrogen were in agreement with the theoretical values for triethylamine. GC/FID by system $\mathrm{A}$ indicated one major peak and five minor impurity peaks, each with less than $0.1 \%$ of the total peak area. GC/FID by system B indicated one major peak and no impurities with areas greater than $0.1 \%$ relative to the total peak area. The overall purity of lot CE/04/01 was determined to be greater than $99 \%$.

An additional analysis was performed by the study laboratory to determine if triethylamine oxide (TEAO), a degradation product that can be found in the test chemical from reaction with oxygen, was present. The presence of TEAO was determined by controlled thermal degradation of TEAO to diethylamine ${ }^{40}$ with subsequent analysis using GC/MS by system C. Results indicated that, if present, the concentration of TEAO was less than $0.1 \%$.

To ensure stability, the test chemical was stored at controlled room temperature in the original shipping containers (55-gallon metal drums). Periodic reanalyses of the bulk chemical were performed by the study laboratory during the 2-week and 3-month studies using GC/FID by system B and no degradation of the test chemical was detected.

\section{F.2. Vapor Generation and Exposure System}

A diagram of the vapor generation and delivery system used in the studies is shown in Figure F-4. A bulk supply of triethylamine was held in an 8-gallon stainless steel chemical reservoir and pumped through a preheater (2-week studies only) into the top of a heated glass column filled with glass beads to increase the surface area for evaporation. Heated nitrogen 
entering the column from below vaporized the chemical as it was conveyed out of the generator. The vapor leaving the generator entered a short vapor distribution manifold. Concentration in the manifold was determined by the chemical pump and nitrogen flow rates. The pressure in the distribution manifold was kept fixed to ensure consistent flow through the manifold and into the chambers as the flow of vapor to each chamber was adjusted. Precision metering valves controlled flow to each chamber. In addition, three-way exposure valves, mounted downstream from all metering valves directed all chemical to exhaust until the generation system was stable and exposures were ready to proceed. When the exposure started, the three-way valve was rotated to allow the flow of triethylamine vapor through the Teflon ${ }^{\circledR}$ delivery line into the chamber inlet duct where it was further mixed and diluted with conditioned chamber air to achieve the desired exposure concentration.

The study laboratory designed the inhalation exposure chamber (Harford Systems Division of Lab Products, Inc., Aberdeen, MD) so that uniform vapor concentrations could be maintained throughout the chamber with the catch pans in place. The total active mixing volume of each chamber was $1.7 \mathrm{~m}^{3}$. A condensation particle counter (Model 3022A, TSI Incorporated, St. Paul, $\mathrm{MN}$ ) was used with and without animals in the exposure chambers to ensure that triethylamine vapor, and not aerosol, was produced. No particle counts above the minimum resolvable level (approximately 200 particles $/ \mathrm{cm}^{3}$ ) were detected.

\section{F.3. Vapor Concentration Monitoring}

Summaries of the chamber vapor concentrations are given in Table F-2and Table F-3. The triethylamine concentrations in the exposure chambers were monitored by an on-line gas chromatograph using system D (Table F-1). Samples were drawn from each exposure chamber through Teflon ${ }^{\circledR}$ sampling lines approximately every 20 minutes during each 6-hour exposure using a 16-port stream-select valve (VALCO Instruments Company, Houston, TX). This valve directed a continuous stream of sampled atmosphere to a six-port sampling valve (VALCO Instruments Company) with a $1 \mathrm{~mL}$ sample loop. Both valves were mounted in a dedicated oven maintained at approximately $150^{\circ} \mathrm{C}$. A vacuum regulator maintained a constant pressure in the sample loop to compensate for variations in sample line pressure, and a flow meter in line between the vacuum regulator and gas chromatograph allowed digital measurement of sample flow.

The on-line gas chromatograph was checked throughout the day for instrument drift against an on-line standard of triethylamine vapor supplied by a standard generator (Kin-Tek, Precision Calibration Systems, La Marque, TX). The on-line gas chromatograph was calibrated on December 5,6, and 9,2002, by a comparison of chamber concentration data to data from grab samples that were collected with acrylic ester sampling tubes $\left(\mathrm{XAD}^{\circledR}-7\right.$, SKC, Inc., Eighty Four, PA) and extracted with methylene chloride containing cyclopentylamine as an internal standard; the grab samples were analyzed by an off-line gas chromatograph using system E. The volumes of gas were sampled at a constant flow rate ensured by a calibrated critical orifice. The off-line gas chromatograph was calibrated with gravimetrically prepared standards of triethylamine and the internal standard in methylene chloride. 


\section{F.4. Chamber Atmosphere Characterization}

Buildup and decay rates for chamber vapor concentrations were determined with and without animals present in the chambers. At a chamber airflow rate of 15 air changes per hour, the theoretical value for the time to achieve $90 \%$ of the target concentration after the beginning of vapor generation $\left(\mathrm{T}_{90}\right)$ and the time for the chamber concentration to decay to $10 \%$ of the target concentration after vapor generation was terminated $\left(\mathrm{T}_{10}\right)$ was approximately 9.4 minutes. For rats and mice in the 2-week studies, $T_{90}$ values ranged from 9 to 10 minutes with animals present; $\mathrm{T}_{10}$ values ranged from 9 to 11 minutes with animals present. For rats and mice in the 3month studies, $\mathrm{T}_{90}$ values ranged from 8 to 11 minutes without animals present and from 11 to 15 minutes with animals present; $\mathrm{T}_{10}$ values ranged from 9 to 10 minutes without animals present and from 11 to 18 minutes with animals present. A T90 value of 12 minutes was selected for all studies.

The uniformity of triethylamine concentration in the inhalation exposure chambers without animals present was evaluated before the 3-month studies began; concentration uniformity with animals in the chambers was measured once during the 2-week and 3-month studies. The vapor concentration was measured using the on-line gas chromatograph and system D (Table F-1) with the stream-selection valve fixed in one position to allow continuous monitoring from a single input line. During the 2-week studies and prior to the 3-month studies, concentrations were measured at 12 chamber positions, one in front and one in back for each of the six possible animal cage unit positions per chamber. During the 3-month studies, concentrations were measured at the regular monitoring port and from sample ports where animals were present. Chamber concentration uniformity was maintained throughout the studies.

The persistence of triethylamine in the chambers after vapor delivery ended was determined by monitoring the concentration in the $1,000 \mathrm{ppm}$ chambers with animals present in the 2-week studies and in the 200 ppm chambers with and without animals present in the 3-month studies. In the 2-week studies, the concentration decreased to $1 \%$ of the target concentration within 21 minutes. In the 3-month studies, the concentration decreased to $1 \%$ of the target concentration within 56 minutes with animals present and within 22 minutes without animals present.

Test article stability in the distribution lines and low and high exposure concentration chambers was characterized during the 2-week and 3-month studies; characterization of the chamber test atmosphere during the first and last 2 hours of one generation day was conducted with animals present in the exposure chambers. Similar stability studies were conducted prior to the start of the 3-month studies; in these studies, exposure chamber measurements were taken from unoccupied chambers. Additional samples were collected from the generator reservoir during the 2 -week studies and prior to the 3-month studies. Samples of the bulk chemical taken from the generator reservoir were diluted with methylene chloride containing diethylamine as an internal standard and analyzed by GC using system F. Samples of the test atmosphere from the distribution lines and exposure chambers were collected with $\mathrm{XAD}^{\circledR}{ }_{-} 7$ (SKC, Inc.) and $\mathrm{ORBO}^{\mathrm{TM}}$ 32 (Supelco Inc., Bellefonte, PA) sorbent tubes, extracted with methylene chloride, and analyzed using GC by a system similar to system B. To assess whether impurities or degradation products co-eluted with the test chemical or the solvent, a second analysis of the test atmosphere samples was performed with GC by system $\mathrm{G}$ using a polar column that permitted resolution of compounds with similar boiling points but small differences in polarity. Some of the samples of 
the test atmosphere from the distribution lines and exposure chambers in these studies contained one impurity with an area greater than $0.1 \%$ of the total peak area; the identity of this impurity was confirmed as diethylamine using GC/MS by system $\mathrm{C}$. The highest concentrations of diethylamine noted in the test atmosphere samples during the 2-week studies and prior to and during the 3 -month studies were $0.16 \%, 0.24 \%$, and $0.34 \%$ of the total peak areas, respectively; the presence of this impurity was attributed to artifacts of sample collection or formation in the injector port. Diethylamine was shown to be present at less than $0.1 \%$ in all samples from the generator reservoir. No evidence of degradation of the test chemical was detected, and no other impurities were detected in any of the reservoir, distribution line, or exposure chamber samples. These results indicated that triethylamine was stable in the exposure system.

Table F-1. Gas Chromatography Systems Used in the Inhalation Studies of Triethylamine ${ }^{a}$

\begin{tabular}{|c|c|c|c|}
\hline Detection System & Column & Carrier Gas & $\begin{array}{c}\text { Oven Temperature } \\
\text { Program }\end{array}$ \\
\hline
\end{tabular}

\section{System A}

Flame ionization

SPB-1, $60 \mathrm{~m} \times 0.32 \mathrm{~mm}, 1.0-\quad$ Nitrogen at $1 \mathrm{~mL} / \mathrm{minute}$ $\mu \mathrm{m}$ film (Supelco, Inc., Bellefonte, PA)

\section{System B}

Flame ionization PTA-5, $30 \mathrm{~m} \times 0.53 \mathrm{~mm}, 3.0-$ Helium at 3 psi head pressure
$\mu \mathrm{m}$ film (Supelco, Inc.)

System C

Mass spectrometry

Rtx $^{\circledR}-5$ amine, $30 \mathrm{~m} \times 0.25 \mathrm{~mm}, 1.0-\mu \mathrm{m}$ film (Restek Corporation, Bellefonte, PA)

Helium at 2.5 psi head pressure

\section{System D}

Flame ionization

Rtx $^{\circledR}-5$ amine, $15 \mathrm{~m} \times 0.53 \mathrm{~mm}, 3.0-\mu \mathrm{m}$ film (Restek Corporation)

\section{System E}

Flame ionization

PTA-5, $30 \mathrm{~m} \times 0.53 \mathrm{~mm}, 3.0-$ $\mu \mathrm{m}$ film (Supelco, Inc.) or Rtx $^{\circledR}-5$ amine, $30 \mathrm{~m} \times 0.53 \mathrm{~mm}, 3.0-\mu \mathrm{m}$ film (Restek Corporation)

\section{System F}

Flame ionization $35^{\circ} \mathrm{C}$ for 3 minutes, then $3^{\circ} \mathrm{C} /$ minute to $45^{\circ} \mathrm{C}$, then $25^{\circ} \mathrm{C} /$ minute to $175^{\circ} \mathrm{C}$, held for 2 minutes

$50^{\circ} \mathrm{C}$ for 5 minutes, then $10^{\circ} \mathrm{C} /$ minute to $300^{\circ} \mathrm{C}$, held for 10 minutes

$35^{\circ} \mathrm{C}$ for 3 minutes, then $3^{\circ} \mathrm{C} /$ minute to $75^{\circ} \mathrm{C}$, then $7^{\circ} \mathrm{C} /$ minute to $260^{\circ} \mathrm{C}$, held for 1 minute
Isothermal at $60^{\circ} \mathrm{C}$

$40^{\circ} \mathrm{C}$ for 1 minute, then $5^{\circ} \mathrm{C} /$ minute to $100^{\circ} \mathrm{C}$, held for 1 minute

$35^{\circ} \mathrm{C}$ for 3 minutes, then
PTA-5, $30 \mathrm{~m} \times 0.53 \mathrm{~mm}, 3.0-$ Helium at 4 psi head pressure $\mu \mathrm{m}$ film (Supelco, Inc.) $3^{\circ} \mathrm{C} /$ minute to $70^{\circ} \mathrm{C}$, then $15^{\circ} \mathrm{C} /$ minute to $150^{\circ} \mathrm{C}$, held for 2 minutes 


\begin{tabular}{|c|c|c|c|}
\hline Detection System & Column & Carrier Gas & $\begin{array}{c}\text { Oven Temperature } \\
\text { Program }\end{array}$ \\
\hline
\end{tabular}

\section{System G}

Flame ionization

$\mathrm{DB}^{\mathrm{TM}}-\mathrm{WAX}$ $30 \mathrm{~m} \times 0.53 \mathrm{~mm}, 1.0-\mu \mathrm{m}$ film (J\&W Scientific, Folsom, $\mathrm{CA})$
Helium at 3 psi head pressure

$35^{\circ} \mathrm{C}$ for 3 minutes, then $3^{\circ} \mathrm{C} /$ minute to $75^{\circ} \mathrm{C}$, then

$7^{\circ} \mathrm{C} /$ minute to $260^{\circ} \mathrm{C}$

aThe gas chromatographs were manufactured by Hewlett-Packard, Inc. (Palo Alto, CA).

Table F-2. Summary of Chamber Concentrations in the Two-week Inhalation Studies of Triethylamine

\begin{tabular}{lccc}
\hline & $\begin{array}{c}\text { Target Concentration } \\
(\mathbf{p p m})\end{array}$ & $\begin{array}{c}\text { Total Number of } \\
\text { Readings }\end{array}$ & $\begin{array}{c}\text { Average Concentration }^{\mathbf{a}} \\
\text { (ppm) }\end{array}$ \\
\hline Rat Chambers & & 218 & $101 \pm 2$ \\
& 100 & 221 & $201 \pm 2$ \\
& 200 & 222 & $399 \pm 6$ \\
& 800 & 20 & $817 \pm 5$ \\
Mouse Chambers & 200 & 20 & $1,009 \pm 8$ \\
& 1,000 & & $101 \pm 2$ \\
& 100 & 237 & $201 \pm 2$ \\
& 200 & 241 & $400 \pm 6$ \\
400 & 242 & $802 \pm 14$ \\
& 800 & 167 & $988 \pm 16$ \\
\hline
\end{tabular}

${ }^{\mathrm{a}}$ Mean \pm standard deviation.

Table F-3. Summary of Chamber Concentrations in the Three-month Inhalation Studies of Triethylamine

\begin{tabular}{ccc}
$\underset{(p p m)}{\text { Target Concentration }}$ & $\begin{array}{c}\text { Total Number of } \\
\text { Readings }\end{array}$ & $\begin{array}{c}\text { Average Concentration } \\
(\mathbf{p p m})\end{array}$ \\
\hline
\end{tabular}

\section{Rat Chambers}

$\begin{array}{ccc}12.5 & 1,285 & 12.5 \pm 0.3 \\ 25 & 1,302 & 25.1 \pm 0.5 \\ 50 & 1,332 & 50.2 \pm 0.9 \\ 100 & 1,332 & 99.9 \pm 2.1 \\ 200 & 1,333 & 201 \pm 4\end{array}$

Mouse Chambers

\begin{tabular}{cl}
12.5 & $12.5 \pm 0.3$ \\
25 & 1,322 \\
\hline
\end{tabular}


Triethylamine, NTP TOX 78

\begin{tabular}{ccc}
\hline $\begin{array}{c}\text { Target Concentration } \\
(\mathbf{p p m})\end{array}$ & $\begin{array}{c}\text { Total Number of } \\
\text { Readings }\end{array}$ & $\begin{array}{c}\text { Average Concentration } \\
\text { (ppm) }\end{array}$ \\
\hline 50 & 1,371 & $50.3 \pm 0.9$ \\
100 & 1,372 & $99.9 \pm 2.1$ \\
200 & 1,373 & $201 \pm 4$ \\
\hline
\end{tabular}

${ }^{\mathrm{a}}$ Mean \pm standard deviation. 
Triethylamine, NTP TOX 78

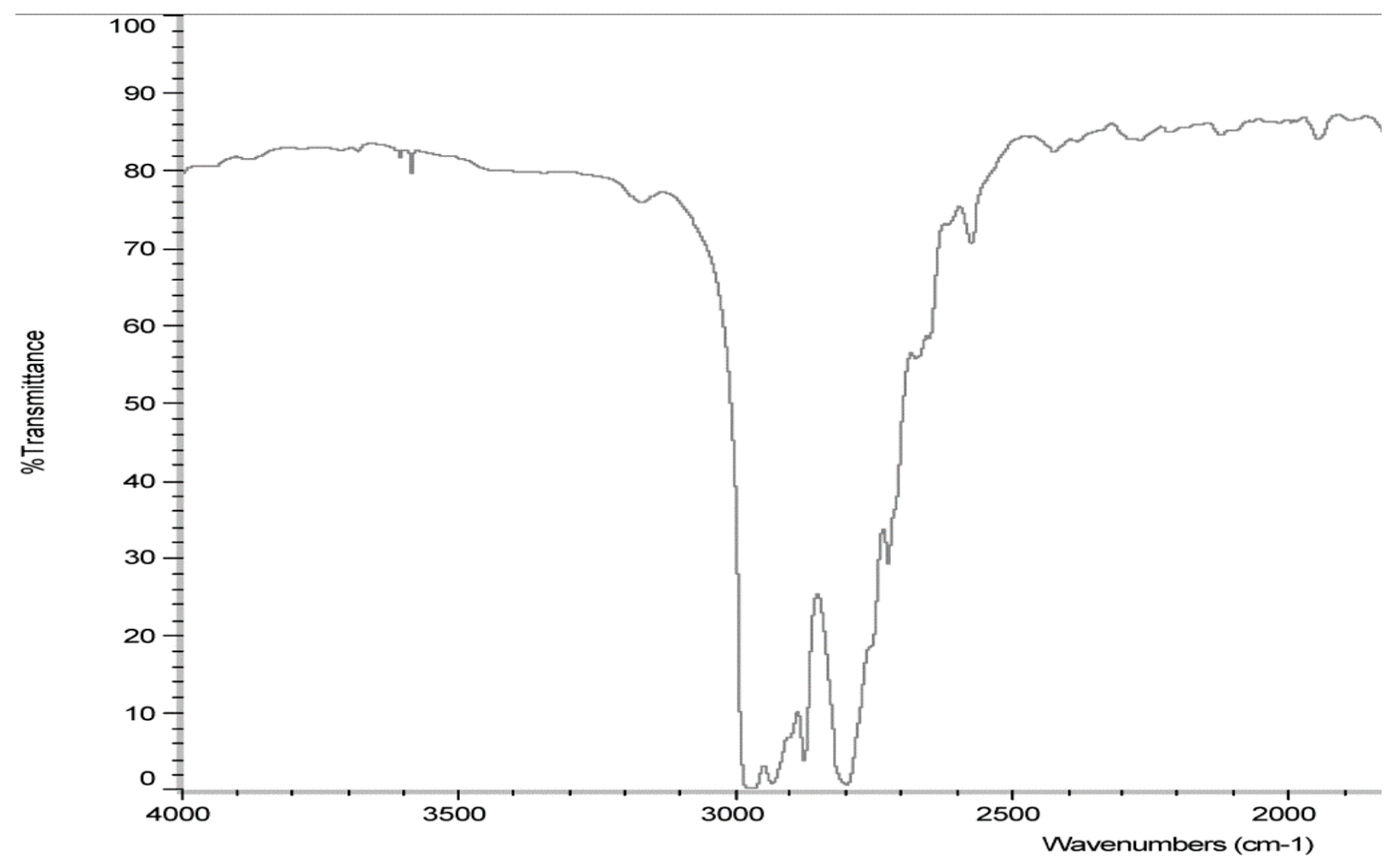

Figure F-1. Infrared Absorption Spectrum of Triethylamine 
Triethylamine, NTP TOX 78

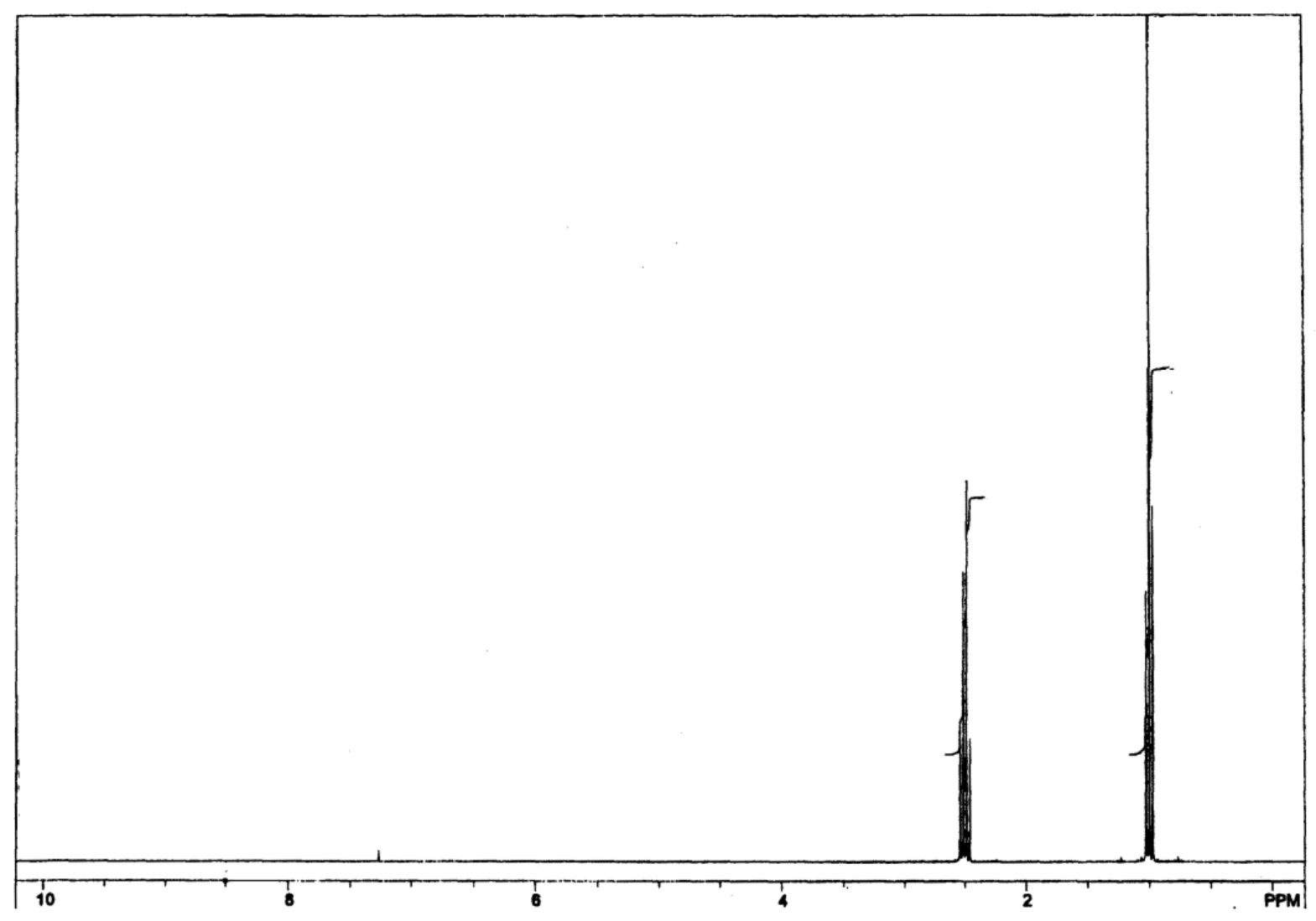

Figure F-2. Proton Nuclear Magnetic Resonance Spectrum of Triethylamine 
Triethylamine, NTP TOX 78

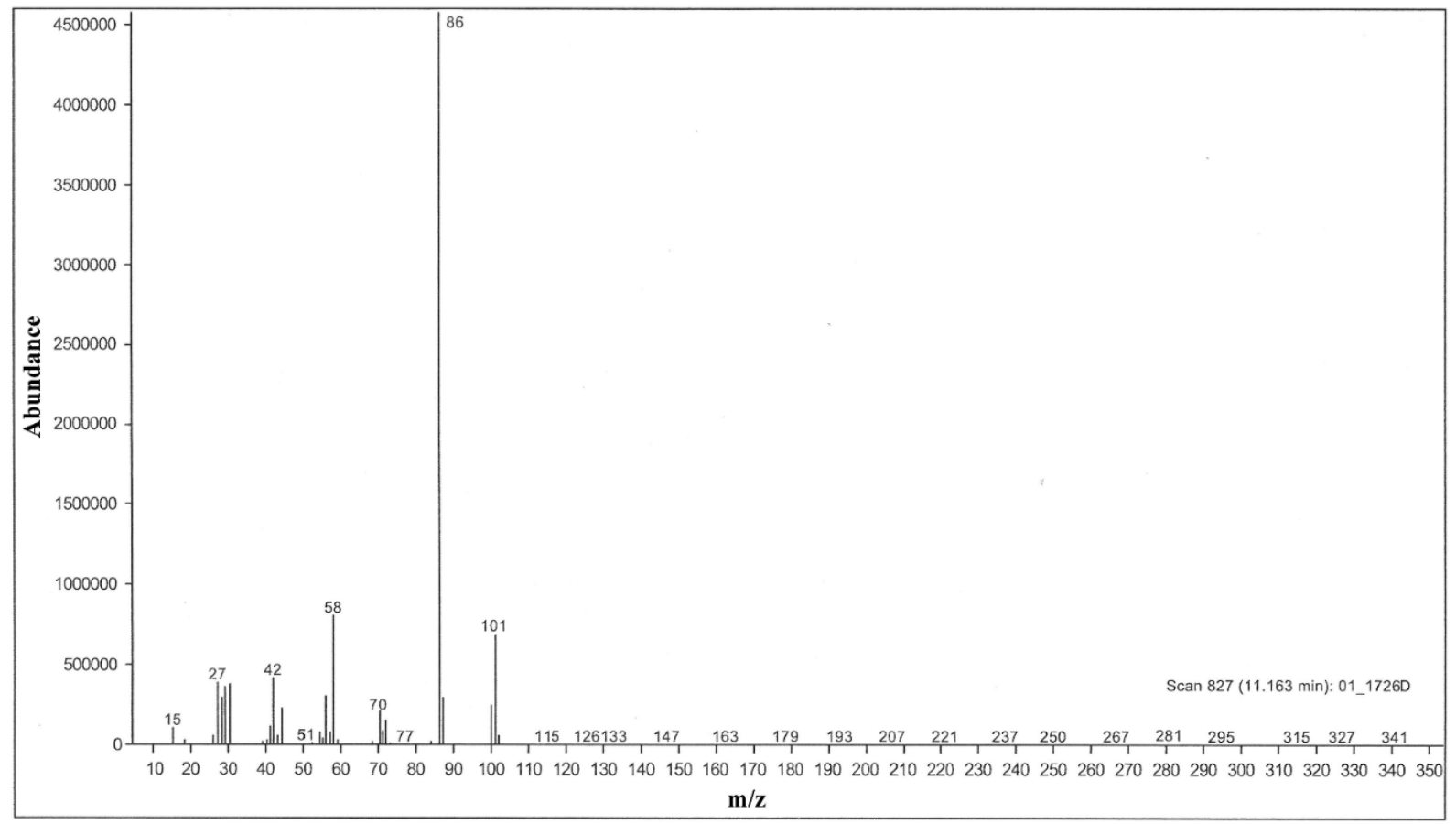

Figure F-3. Low Resolution Mass Spectrum of Triethylamine 


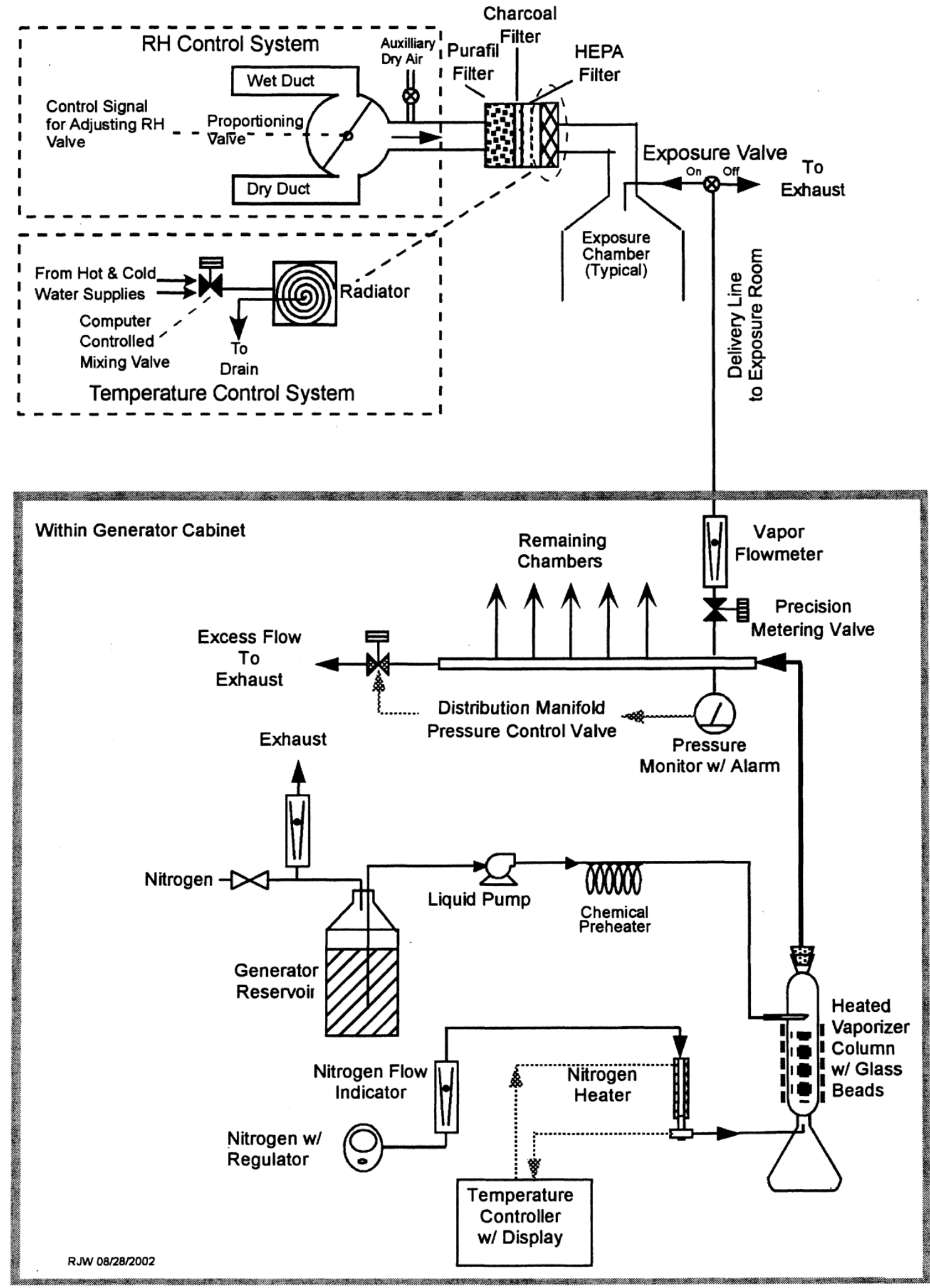

Figure F-4. Schematic of the Vapor Generation and Delivery System in the Inhalation Studies of Triethylamine 


\section{Appendix G. Ingredients, Nutrient Composition, and Contaminant Levels in NTP 2000 Rat and Mouse Ration}

\section{Tables}

Table G-1. Ingredients of NTP-2000 Rat and Mouse Ration .... G-2

Table G-2. Vitamins and Minerals in NTP-2000 Rat and Mouse Ration. G-3

Table G-3. Nutrient Composition of NTP-2000 Rat and Mouse Ration G-4

Table G-4. Contaminant Levels in NTP-2000 Rat and Mouse Ration G-6 
Triethylamine, NTP TOX 78

Table G-1. Ingredients of NTP-2000 Rat and Mouse Ration

\section{Ingredients}

Ground hard winter wheat

Ground \#2 yellow shelled corn

Wheat middlings

Oat hulls

Alfalfa meal (dehydrated, $17 \%$ protein)

Purified cellulose

Soybean meal (49\% protein)

Fish meal (60\% protein)

Corn oil (without preservatives)

Soy oil (without preservatives)

Dried brewer's yeast

Calcium carbonate (USP)

Vitamin premix ${ }^{\mathrm{a}}$

Mineral premix ${ }^{\mathrm{b}}$

Calcium phosphate, dibasic (USP)

Sodium chloride

Choline chloride (70\% choline)

Methionine

${ }^{\mathrm{a}}$ Wheat middlings as carrier.

${ }^{\mathrm{b}} \mathrm{Calcium}$ carbonate as carrier.

\section{Percent by Weight}

22.26

22.18

15.0

8.5

7.5

5.5

5.0

4.0

3.0

3.0

1.0

0.9

0.5

0.5

0.4

0.3

0.26

0.2 
Table G-2. Vitamins and Minerals in NTP-2000 Rat and Mouse Ration ${ }^{\text {a }}$

\begin{tabular}{|c|c|c|}
\hline & Amount & Source \\
\hline \multicolumn{3}{|l|}{ Vitamins } \\
\hline A & $4,000 \mathrm{IU}$ & Stabilized vitamin A palmitate or acetate \\
\hline $\mathrm{D}$ & $1,000 \mathrm{IU}$ & D-activated animal sterol \\
\hline $\mathrm{K}$ & $1.0 \mathrm{mg}$ & Menadione sodium bisulfite complex \\
\hline A-Tocopheryl acetate & $100 \mathrm{IU}$ & - \\
\hline Niacin & $23 \mathrm{mg}$ & - \\
\hline Folic acid & $1.1 \mathrm{mg}$ & - \\
\hline$d$-pantothenic acid & $10 \mathrm{mg}$ & $d$-Calcium pantothenate \\
\hline Riboflavin & $3.3 \mathrm{mg}$ & - \\
\hline Thiamine & $4 \mathrm{mg}$ & Thiamine mononitrate \\
\hline $\mathrm{B}_{12}$ & $52 \mu \mathrm{g}$ & - \\
\hline Pyridoxine & $6.3 \mathrm{mg}$ & Pyridoxine hydrochloride \\
\hline Biotin & $0.2 \mathrm{mg}$ & $d$-Biotin \\
\hline \multicolumn{3}{|l|}{ Minerals } \\
\hline Magnesium & $514 \mathrm{mg}$ & Magnesium oxide \\
\hline Iron & $35 \mathrm{mg}$ & Iron sulfate \\
\hline Zinc & $12 \mathrm{mg}$ & Zinc oxide \\
\hline Manganese & $10 \mathrm{mg}$ & Manganese oxide \\
\hline Copper & $2.0 \mathrm{mg}$ & Copper sulfate \\
\hline Iodine & $0.2 \mathrm{mg}$ & Calcium iodate \\
\hline Chromium & $0.2 \mathrm{mg}$ & Chromium acetate \\
\hline
\end{tabular}

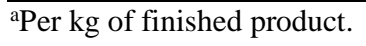


Triethylamine, NTP TOX 78

Table G-3. Nutrient Composition of NTP-2000 Rat and Mouse Ration

\begin{tabular}{|c|c|c|c|}
\hline Nutrient & Mean \pm Standard Deviation & Range & Number of Samples \\
\hline Protein (\% by weight) & $14.9 \pm 0.30$ & $14.6-15.2$ & 3 \\
\hline Crude fat ( $\%$ by weight) & $8.3 \pm 0.35$ & $7.9-8.6$ & 3 \\
\hline Crude fiber ( $\%$ by weight) & $8.8 \pm 0.37$ & $8.4-9.1$ & 3 \\
\hline Ash (\% by weight) & $5.0 \pm 0.00$ & 5.0 & 3 \\
\hline \multicolumn{4}{|c|}{ Amino acids (\% of total diet) } \\
\hline Arginine & $0.783 \pm 0.070$ & $0.670-0.970$ & 22 \\
\hline Cystine & $0.220 \pm 0.024$ & $0.150-0.250$ & 22 \\
\hline Glycine & $0.701 \pm 0.041$ & $0.620-0.800$ & 22 \\
\hline Histidine & $0.352 \pm 0.077$ & $0.270-0.680$ & 22 \\
\hline Isoleucine & $0.546 \pm 0.044$ & $0.430-0.660$ & 22 \\
\hline Leucine & $1.095 \pm 0.067$ & $0.960-1.240$ & 22 \\
\hline Lysine & $0.711 \pm 0.114$ & $0.310-0.860$ & 22 \\
\hline Methionine & $0.409 \pm 0.046$ & $0.260-0.490$ & 22 \\
\hline Phenylalanine & $0.628 \pm 0.040$ & $0.540-0.720$ & 22 \\
\hline Threonine & $0.505 \pm 0.043$ & $0.430-0.610$ & 22 \\
\hline Tryptophan & $0.150 \pm 0.028$ & $0.110-0.200$ & 22 \\
\hline Tyrosine & $0.401 \pm 0.061$ & $0.280-0.540$ & 22 \\
\hline Valine & $0.665 \pm 0.043$ & $0.550-0.730$ & 22 \\
\hline \multicolumn{4}{|c|}{ Essential fatty acids ( $\%$ of total diet) } \\
\hline Linoleic & $3.95 \pm 0.259$ & $3.49-4.55$ & 22 \\
\hline Linolenic & $0.30 \pm 0.032$ & $0.21-0.35$ & 22 \\
\hline \multicolumn{4}{|l|}{ Vitamins } \\
\hline Vitamin A (IU/kg) & $5,020 \pm 99$ & $4,030-6,000$ & 3 \\
\hline Vitamin D (IU/kg) & $1,000^{\mathrm{a}}$ & - & - \\
\hline$\alpha$-Tocopherol (ppm) & $80.6 \pm 22.03$ & $27.0-124.0$ & 22 \\
\hline Thiamine (ppm) $)^{\mathrm{b}}$ & $7.8 \pm 1.34$ & $6.3-8.8$ & 3 \\
\hline Riboflavin (ppm) & $7.6 \pm 2.89$ & $4.20-17.50$ & 22 \\
\hline Niacin (ppm) & $78.9 \pm 9.08$ & $66.4-98.2$ & 22 \\
\hline Pantothenic acid (ppm) & $26.9 \pm 12.63$ & $17.4-81.0$ & 22 \\
\hline Pyridoxine $(\mathrm{ppm})^{\mathrm{b}}$ & $9.54 \pm 1.99$ & $6.44-13.7$ & 22 \\
\hline Folic acid (ppm) & $1.62 \pm 0.48$ & $1.15-3.27$ & 22 \\
\hline Biotin (ppm) & $0.32 \pm 0.10$ & $0.2-0.704$ & 22 \\
\hline Vitamin $B_{12}(p p b)$ & $53.6 \pm 39.6$ & $18.3-174.0$ & 22 \\
\hline Choline (ppm) ${ }^{\mathrm{b}}$ & $2,846 \pm 485$ & $1,820-3,790$ & 22 \\
\hline
\end{tabular}


Triethylamine, NTP TOX 78

\begin{tabular}{lccc}
\hline \multicolumn{1}{c}{ Nutrient } & Mean \pm Standard Deviation & Range & Number of Samples \\
\hline Minerals & & & \\
Calcium (\%) & $0.992 \pm 0.033$ & $0.969-1.030$ & 3 \\
Phosphorus (\%) & $0.603 \pm 0.036$ & $0.569-0.641$ & 22 \\
Potassium (\%) & $0.666 \pm 0.030$ & $0.626-0.733$ & 22 \\
Chloride (\%) & $0.386 \pm 0.039$ & $0.300-0.474$ & 22 \\
Sodium (\%) & $0.189 \pm 0.016$ & $0.160-0.222$ & 22 \\
Magnesium (\%) & $0.216 \pm 0.062$ & $0.185-0.49$ & 22 \\
Sulfur (\%) & $0.170 \pm 0.029$ & $0.116-0.209$ & 22 \\
Iron (ppm) & $186 \pm 39.2$ & $135-311$ & 22 \\
Manganese (ppm) & $51.4 \pm 10.28$ & $21.0-73.1$ & 22 \\
Zinc (ppm) & $53.4 \pm 8.46$ & $43.3-78.5$ & 22 \\
Copper (ppm) & $7.01 \pm 2.562$ & $3.21-16.3$ & 22 \\
Iodine (ppm) & $0.503 \pm 0.206$ & $0.158-0.972$ & 22 \\
Chromium (ppm) & $0.694 \pm 0.276$ & $0.330-1.380$ & \\
Cobalt (ppm) & $0.256 \pm 0.164$ & $0.098-0.864$ & \\
\hline
\end{tabular}

${ }^{\mathrm{a} F r o m}$ formulation.

${ }^{\mathrm{b}}$ As hydrochloride (thiamine and pyridoxine) or chloride (choline). 
Triethylamine, NTP TOX 78

Table G-4. Contaminant Levels in NTP-2000 Rat and Mouse Ration ${ }^{\mathrm{a}}$

\begin{tabular}{|c|c|c|c|}
\hline & Mean \pm Standard Deviation ${ }^{b}$ & Range & Number of Samples \\
\hline \multicolumn{4}{|l|}{ Contaminants } \\
\hline Arsenic (ppm) & $0.50 \pm 0.00$ & 0.50 & 3 \\
\hline Cadmium (ppm) & $0.05 \pm 0.015$ & $0.04-0.07$ & 3 \\
\hline Lead (ppm) & $0.06 \pm 0.005$ & $0.06-0.07$ & 3 \\
\hline Mercury (ppm) & $<0.02$ & - & 3 \\
\hline Selenium (ppm) & $0.22 \pm 0.00$ & 0.22 & 3 \\
\hline Aflatoxins (ppb) & $<5.00$ & - & 3 \\
\hline Nitrate nitrogen $(\mathrm{ppm})^{\mathrm{c}}$ & $17.03 \pm 6.64$ & $10.0-23.2$ & 3 \\
\hline Nitrite nitrogen $(\mathrm{ppm})^{\mathrm{c}}$ & $<0.61$ & - & 3 \\
\hline BHA $(\mathrm{ppm})^{\mathrm{d}}$ & $<1.0$ & - & 3 \\
\hline BHT $(\mathrm{ppm})^{\mathrm{d}}$ & $<1.0$ & - & 3 \\
\hline Aerobic plate count $(\mathrm{CFU} / \mathrm{g})$ & $10 \pm 0$ & 10 & 3 \\
\hline Coliform (MPN/g) & $3.0 \pm 0$ & 3.0 & 3 \\
\hline Escherichia coli (MPN/g) & $<10$ & - & 3 \\
\hline Salmonella (MPN/g) & Negative & - & 3 \\
\hline Total nitrosamines $(\mathrm{ppb})^{\mathrm{e}}$ & $6.6 \pm 2.75$ & $3.4-8.4$ & 3 \\
\hline$N$-Nitrosodimethylamine $(\mathrm{ppb})^{\mathrm{e}}$ & $5.2 \pm 2.86$ & $1.9-6.9$ & 3 \\
\hline$N$-Nitrosopyrrolidine $(\mathrm{ppb})^{\mathrm{e}}$ & $1.4 \pm 0.32$ & $1.0-1.6$ & 3 \\
\hline \multicolumn{4}{|l|}{ Pesticides (ppm) } \\
\hline$\alpha-\mathrm{BHC}$ & $<0.01$ & - & 3 \\
\hline$\beta$-BHC & $<0.02$ & - & 3 \\
\hline$\gamma$-BHC & $<0.01$ & - & 3 \\
\hline$\delta$-BHC & $<0.01$ & - & 3 \\
\hline Heptachlor & $<0.01$ & - & 3 \\
\hline Aldrin & $<0.01$ & - & 3 \\
\hline Heptachlor epoxide & $<0.01$ & - & 3 \\
\hline DDE & $<0.01$ & - & 3 \\
\hline DDD & $<0.01$ & - & 3 \\
\hline DDT & $<0.01$ & - & 3 \\
\hline $\mathrm{HCB}$ & $<0.01$ & - & 3 \\
\hline Mirex & $<0.01$ & - & 3 \\
\hline Methoxychlor & $<0.05$ & - & 3 \\
\hline Dieldrin & $<0.01$ & - & 3 \\
\hline Endrin & $<0.01$ & - & 3 \\
\hline
\end{tabular}


Triethylamine, NTP TOX 78

\begin{tabular}{|c|c|c|c|}
\hline & Mean \pm Standard Deviation ${ }^{b}$ & Range & Number of Samples \\
\hline Telodrin & $<0.01$ & - & 3 \\
\hline Chlordane & $<0.05$ & - & 3 \\
\hline Toxaphene & $<0.10$ & - & 3 \\
\hline Estimated PCBs & $<0.20$ & - & 3 \\
\hline Ronnel & $<0.01$ & - & 3 \\
\hline Ethion & $<0.02$ & - & 3 \\
\hline Trithion & $<0.05$ & - & 3 \\
\hline Diazinon & $<0.10$ & - & 3 \\
\hline Methyl chlorpyrifos & $0.102 \pm 0.083$ & $0.036-0.196$ & 3 \\
\hline Methyl parathion & $<0.02$ & - & 3 \\
\hline Ethyl parathion & $<0.02$ & - & 3 \\
\hline Malathion & $0.121 \pm 0.080$ & $0.038-0.198$ & 3 \\
\hline Endosulfan I & $<0.01$ & - & 3 \\
\hline Endosulfan II & $<0.01$ & - & 3 \\
\hline Endosulfan sulfate & $<0.03$ & - & 3 \\
\hline
\end{tabular}

${ }^{\mathrm{a}}$ All samples were irradiated. $\mathrm{CFU}=$ colony-forming units; $\mathrm{MPN}=$ most probable number; $\mathrm{BHC}=$ hexachlorocyclohexane or benzene hexachloride.

${ }^{b}$ For values less than the limit of detection, the detection limit is given as the mean.

'Sources of contamination: alfalfa, grains, and fish meal.

${ }^{\mathrm{d}}$ Sources of contamination: soy oil and fish meal.

${ }^{\mathrm{e}}$ All values were corrected for percent recovery. 


\section{Appendix H. Sentinel Animal Program Sentinel Animal Program}

\section{Table of Contents}

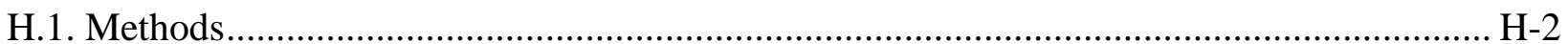

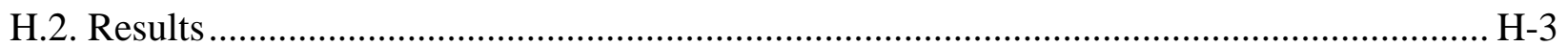

Tables

Table H-1. Laboratory Methods and Agents Tested for in the Sentinel Animal Program ......... H-2 


\section{H.1. Methods}

Rodents used in the Carcinogenesis Program of the National Toxicology Program are produced in optimally clean facilities to eliminate potential pathogens that may affect study results. The Sentinel Animal Program is part of the periodic monitoring of animal health that occurs during the toxicologic evaluation of chemical compounds. Under this program, the disease state of the rodents is monitored via serology on sera from extra (sentinel) animals in the study rooms. These animals and the study animals are subject to identical environmental conditions. The sentinel animals come from the same production source and weanling groups as the animals used for the studies of chemical compounds.

Serum samples were collected from five male and five female chamber control rats and mice at the end of the 2-week studies. In the 3-month studies, serum samples were collected from five male and five female sentinel rats and mice at 2 weeks and from five male and five female chamber control rats and mice at study termination. Blood from each animal was collected and allowed to clot, and the serum was separated. Samples were processed appropriately, and antibody titers were determined by BioReliance Corporation (Rockville, MD). The laboratory methods and agents for which testing was performed are tabulated below; the times at which samples were collected during the studies are also listed.

Table H-1. Laboratory Methods and Agents Tested for in the Sentinel Animal Program

\begin{tabular}{ll}
\hline \multicolumn{1}{c}{ Method and Test } & \multicolumn{1}{c}{ Time of Collection } \\
\hline Rats & \\
2-week study & \\
ELISA & Study termination \\
H-1 (Toolan's H-1 virus) & Study termination \\
KRV (Kilham rat virus) & Study termination \\
Mycoplasma pulmonis & Study termination \\
PVM (pneumonia virus of mice) & Study termination \\
RCV/SDA (rat coronavirus/sialodacryoadenitis virus) & Study termination \\
Sendai & \\
3-month study & \\
ELISA & \\
H-1 & 2 weeks \\
KRV & 2 weeks \\
Mycoplasma arthritidis & Study termination \\
M. pulmonis & 2 weeks, study termination \\
PVM & 2 weeks, study termination \\
RCV/SDA & 2 weeks, study termination \\
Sendai & 2 weeks, study termination \\
\hline
\end{tabular}




\section{Triethylamine, NTP TOX 78}

\begin{tabular}{|c|c|}
\hline Method and Test & Time of Collection \\
\hline \multicolumn{2}{|l|}{ Immunofluorescence Assay } \\
\hline Parvovirus & Study termination \\
\hline \multicolumn{2}{|l|}{ Mice } \\
\hline \multicolumn{2}{|l|}{ 2-week study } \\
\hline \multicolumn{2}{|l|}{ ELISA } \\
\hline MHV (mouse hepatitis virus) & Study termination \\
\hline MVM (minute virus of mice) & Study termination \\
\hline M. pulmonis & Study termination \\
\hline PVM & Study termination \\
\hline Sendai & Study termination \\
\hline TMEV (Theiler's mouse encephalomyelitis virus) & Study termination \\
\hline \multicolumn{2}{|l|}{ 3-month study } \\
\hline \multicolumn{2}{|l|}{ ELISA } \\
\hline Ectromelia virus & Study termination \\
\hline EDIM (epizootic diarrhea of infant mice) & Study termination \\
\hline LCM (lymphocytic choriomeningitis virus) & Study termination \\
\hline Mouse adenoma virus & Study termination \\
\hline MCMV (mouse cytomegalovirus) & Study termination \\
\hline MHV & 2 weeks, study termination \\
\hline MVM & 2 weeks \\
\hline M. arthritidis & Study termination \\
\hline M. pulmonis & 2 weeks, study termination \\
\hline PVM & 2 weeks, study termination \\
\hline Reovirus & Study termination \\
\hline Sendai & 2 weeks, study termination \\
\hline TMEV & 2 weeks, study termination \\
\hline \multicolumn{2}{|l|}{ Immunofluorescence Assay } \\
\hline Parvovirus & Study termination \\
\hline
\end{tabular}

\section{H.2. Results}

All test results were negative. 


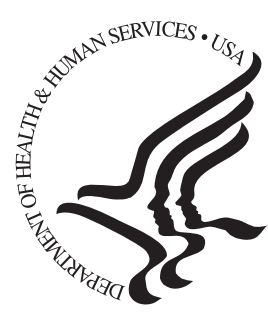

\section{National Toxicology Program}

NTP Central Data Management, MD EC-03

National Institute of Environmental Health Sciences

P.O. Box 12233

Research Triangle Park, NC 27709

http://ntp.niehs.nih.gov 